TATHYANE HARUMI NAKAJIMA TESHIMA

Investigação da atividade apoptótica na abertura luminal dos ductos das glândulas salivares:

análise comparativa entre modelo animal e humano 
TATHYANE HARUMI NAKAJIMA TESHIMA

Investigação da atividade apoptótica na abertura luminal dos ductos das glândulas salivares: análise comparativa entre modelo animal e humano

\section{Versão Original}

Tese apresentada à Faculdade de Odontologia da Universidade de São Paulo, para a obter o título de Doutor em Ciências pelo Programa de PósGraduação em Diagnóstico Bucal

Orientadora: Profa. Dra. Silvia Vanessa Lourenço

São Paulo 
Autorizo a reprodução e divulgação total ou parcial deste trabalho, por qualquer meio convencional ou eletrônico, para fins de estudo e pesquisa, desde que citada a fonte.

\section{Catalogação-na-Publicação}

Serviço de Documentação Odontológica

Faculdade de Odontologia da Universidade de São Paulo

Teshima, Tathyane Harumi Nakajima.

Investigação da atividade apoptótica na abertura luminal dos ductos das glândulas salivares: análise comparativa entre modelo animal e humano / Tathyane Harumi Nakajima Teshima ; orientador Silvia Vanessa Lourenço. -- São Paulo, 2015.

138 p. : fig., tab.; $30 \mathrm{~cm}$.

Tese (Doutorado) -- Programa de Pós-Graduação em

Odontologia. Área de Concentração: Diagnóstico Bucal. -- Faculdade de Odontologia da Universidade de São Paulo.

Versão original

1. Glândulas salivares. 2. Morfogênese. 3. Apoptose. 4. Caspases. I. Lourenço, Silvia Vanessa. II. Título. 
Teshima TH. Investigação da atividade apoptótica na abertura luminal dos ductos das glândulas salivares: análise comparativa entre modelo animal e humano Tese apresentada à Faculdade de Odontologia da Universidade de São Paulo, para a obtenção do título de Doutor pelo Programa de Pós-Graduação em Diagnóstico Bucal.

Aprovado em:

\section{Banca Examinadora}

Prof(a). Dr(a).:

Instituição: Julgamento:

$\operatorname{Prof}(a) \cdot \operatorname{Dr}(\mathrm{a}) .:$

Instituição: Julgamento:

Prof(a). Dr(a).:

Instituição: Julgamento:

Prof(a). Dr(a).:

Instituição: Julgamento:

Prof(a). Dr(a).:

Instituição: Julgamento: 
Dedico este trabalho,

À minha mãe, Elisa Satomi Nakajima, avó, Sumie Nakajima, e ao meu irmão, Edson Jun Nakajima Teshima, que representam a base sólida da minha existência e que sempre acreditaram no meu potencial. De maneira discreta e precisa, me dão força e segurança imprescindíveis para seguir em frente, de cabeça erguida e de sorriso aberto. Toda a minha gratidão e meu carinho por serem infalivelmente meu porto seguro.

Aos meus bisavós Kayoko e Yugo Fushiguro (in memorian) por todo o amor e exemplo que me deram até o último dia de suas vidas em todas as suas particularidades. Tenho muito orgulho de poder dedicar essa grande conquista a vocês.

Aos meus tios Prof. Dr. Tadaaki Ando (in memorian) e Misue Ando por todo o cuidado e dedicação durante minha infância, me acolhendo no momento mais crítico do meu crescimento. Não obstante, se dispuseram a me apoiar incessantemente ao escolher minha carreira profissional com muita satisfação de também seguir a Odontologia e a vida acadêmica. 
Às minhas irmãs de coração Renata Calábria Santos Costa (in memorian) e Renata França Bezerra de Macedo com quem pude sempre contar ao alcance de um pensamento, dividindo uma das melhores fases das nossas vidas. Três corações em um só, como sempre foi e sempre será.

Àquele que hoje representa um dos meus pilares mais fortes, Andrew Christian Foye, que tornou um dos momentos mais significativos da minha vida ainda mais especial. Obrigada por ser tão presente, atencioso, compreensivo e me fazer sentir estar no caminho certo, sempre. 
À minha orientadora Profa. Dra. Silvia Vanessa Lourenço por toda a dedicação e aprendizado durante quase dez anos de convivência. Meu agradecimento torna-se mais especial por toda admiração que tenho por sua competência e seu amor por ensinar e crescer junto com os seus alunos. Obrigada por todas as oportunidades que me ofereceu até hoje e por sempre me incentivar a ir além do que imagino ser capaz de alcançar, confiando em meu potencial incondicionalmente. Obrigada por fazer meu caminho profissional, e por vezes pessoal, menos sofrido, mais esperançoso e sempre mais lindo com o seu jeito peculiar de ser. 


\section{AGRADECIMENTOS}

À Faculdade de Odontologia da Universidade de São Paulo (FOUSP) por representar minha base profissional, acolhendo meus primeiros passos em direção à carreira que escolhi e despertando meus melhores desejos de sempre melhorar. Como uma segunda casa, me apresentou pessoas incríveis com quem pude aprender e compartilhar experiências importantes das quais sempre terei orgulho e muita gratidão.

À Fundação de Amparo à Pesquisa do Estado de São Paulo (FAPESP) e ao Conselho Nacional de Desenvolvimento Científico e Tecnológico (CNPq) pelo auxílio financeiro e incentivo à pesquisa durante todos esses anos de dedicação.

Aos professores e funcionários do Programa de Pós-Graduação de Diagnóstico Bucal e Patologia Oral da FOUSP por toda a estrutura oferecida para a realização deste trabalho e para o meu crescimento acadêmico. Imenso agradecimento também a todos do Instituto de Medicina Tropical (IMT) da Faculdade de Medicina da USP e do Departamento de Desenvolvimento Craniofacial e de Biologia das Células-Tronco do King's College London (Reino Unido) por todo o suporte e aprendizado.

Ao Prof. Dr. Marcello Menta Simonsen Nico e à Profa. Dra. Silvia Vanessa Lourenço pela oportunidade em frequentar o Hospital das Clínicas da Faculdade de Medicina da Universidade de São Paulo (HCFMUSP) e participar dos ambulatórios de Estomatologia e Dermatologia e de Cirurgia de Cabeça e Pescoço. O aprendizado obtido durante essas experiências foi indescritível e ampliou imensamente meu olhar clínico com relação aos pacientes e minha percepção sobre a importância do convívio profissional multidisciplinar.

À Profa. Dra. Abigail Saffron Tucker pela oportunidade de realizar meu estágio no exterior, a qual expandiu grandiosamente meus conhecimentos acadêmicos, profissionais e pessoais. Agradeço pela confiança, pelo aprendizado e por todo o suporte oferecido que foram fundamentais para me incentivar a continuar a crescer na pesquisa e a sempre buscar cada vez mais ensinamentos. Estendo esse 
agradecimento a todos os amigos e colegas que conheci no King's College London, que fizeram dessa experiência um grande ganho profissional e pessoal.

À Dra. Cláudia Malheiros Coutinho-Camillo pela grande contribuição na confecção inicial deste trabalho e no apoio incondicional durante sua execução, particularmente sempre com sua gentileza e simpatia.

À Profa. Dra. Regina Schultz por contribuir com este trabalho, disponibilizando material de grande valor que tornou essa pesquisa possível.

A todos os amigos da pós-graduação que compartilharam vitórias e desapontamentos durante o curso de formação acadêmica, tornando-os mais amenos e divertidos quando enfrentados juntos. Também aos amigos que a vida me apresentou, que foram importantes à sua maneira em cada etapa vencida. Agradeço especialmente aos queridos amigos que estiveram intensamente presentes em diversos momentos dessa importante trajetória, Sheyla Lopes, Daniella Antunes, Ana Maria Hoyos Cadavid, Douglas Magno, Milena Monteiro, Fernanda de Paula, Thais Borguezan, Carolina Mussi, Priscilla Tobouti, Fernanda Pigatti, Carina Esteves, Felipe Daltoé, Juliana Seo, Renata lañez, Vicky Scorcione, João Paulo Peixoto e a cada um que contribuiu de alguma forma para este trabalho. 


\section{RESUMO}

Teshima THN. Investigação da atividade apoptótica na abertura luminal dos ductos das glândulas salivares: análise comparativa entre modelo animal e humano [tese] São Paulo: Universidade de São Paulo, Faculdade de Odontologia; 2015. Versão Original.

As glândulas salivares são estruturas essenciais para a manutenção da homeostase da cavidade oral pela síntese e secreção do fluido salivar. A disfunção ou perda permanente das glândulas salivares causadas por radioterapia, doenças inflamatórias ou desordens congênitas elevam principalmente o risco de infecções da mucosa oral e de estruturas dentárias, além de potencialmente prejudicar funções fisiológicas como fala, mastigação e paladar, diretamente interferindo na qualidade de vida dos indivíduos afetados. Os tratamentos atualmente disponíveis são apenas paliativos, ressaltando a necessidade de se compreender melhor os processos embriogênicos a fim de desenvolver novas estratégias terapêuticas capazes de regenerar as glândulas salivares. O princípio da formação das glândulas salivares baseia-se na coordenação de diversos processos morfogenéticos, e este trabalho foca particularmente em investigar a formação do espaço luminal do sistema de ductos, uma vez que a adequada abertura dos lumens é um processo essencial para a secreção salivar. Relata-se que a remoção das células centrais dos cordões sólidos epiteliais por morte celular apoptótica é o principal mecanismo de abertura do espaço luminal dos futuros ductos glandulares em camundongos. Porém, pouco se sabe sobre o controle temporal da apoptose durante o desenvolvimento glandular e sobre seu comportamento em glândulas salivares humanas. Neste trabalho, o perfil de expressão de diversas proteínas envolvidas na cascata apoptótica em glândulas salivares fetais humanas foi analisado de acordo com cada estágio morfogenético por imunoistoquímica (Bax, Bak, Bad, Bid, Bcl-2, Bcl-x, Bcl-xL, caspase-3 clivada, caspases-6, -7 e -9, apaf-1, survivina e citocromo c). As análises semi-qualitativas resultaram em negatividade apenas para as proteínas Bcl-2, Bad, Bid e caspase-3 clivada em todas as fases de 
desenvolvimento. A expressão nuclear de Bax e Bak foi identificada em presumidos espaços luminais em estágios precoces, enquanto $\mathrm{Bcl}-\mathrm{xL}$ foi o fator antiapoptótico da família Bcl-2 que exibiu expressão nuclear mais importante. Caspases-6, -7 e -9 foram positivas em todas as fases, e a ausência de caspase-3 clivada sugere caspase-7 como principal caspase efetora da apoptose em desenvolvimento de glândulas salivares humanas. Ambos os componentes do complexo apoptossomo foram positivos durante o desenvolvimento glandular, e o inibidor survivina demonstrou mais positividade nuclear em estágios mais avançados. Ao observar a expressão de reguladores apoptóticos durante o desenvolvimento glandular humano, foram realizados experimentos funcionais com culturas de tecido glandular de camundongos para avaliar o papel das caspases durante a formação desta estrutura. Inicialmente detectou-se a atividade apoptótica em glândulas salivares de camundongos albinos no centro dos cordões epiteliais primários a partir de estágios precoces de desenvolvimento através de TUNEL e caspase-3 clivada. A partir disso, foi realizada a inibição apoptótica funcional in vitro durante o mesmo período, que resultou em ductos significativamente mais amplos e em defeitos morfológicos importantes nas estruturas luminal e acinar. Este trabalho evidenciou portanto atividade apoptótica durante a formação de glândulas salivares humanas e de camundongo, expressando-se em fases mais precoces do que reportadas anteriormente. Além disso, a ausência de Bad e Bid indica que a via intrínseca está mais ativa que a extrínseca, e distintos perfis de expressão da maioria das moléculas sugere adicionais funções não-apoptóticas durante a morfogênese glandular.

Palavras-chave: Glândulas salivares. Morfogênese. Apoptose. Caspases. 


\section{ABSTRACT}

Teshima THN. Investigation of apoptotic activity in the lumen formation of salivary gland ducts: comparative analysis between animal and human based models [thesis] São Paulo: Universidade de São Paulo, Faculdade de Odontologia; 2015. Versão Original.

Salivary glands are essential structures for the maintenance of homeostasis of the oral cavity by synthesizing and secreting saliva. Permanent dysfunction or loss of salivary glands caused by radiotherapies, inflammatory diseases or congenital disorders increase mainly the risk of infections of the oral mucosa and tooth surface, also impairing physiological functions as speech, mastication and taste, directly interfering in quality of life. Current treatments are only palliative-based, which highlights the need of having a better understanding of embryonic processes to develop therefore new therapeutic strategies able to regenerate salivary glands. The development of glandular secretory units and ductal system involves the coordination of several morphogenetic processes, and this study particularly focuses in investigating the formation of the lumenal space of the ductal system, as the proper lumen opening is an essential step for the salivary secretion. The clearance of the central cells of developing solid epithelial stalks by apoptotic cell death is the main mechanism of lumen space opening within presumptive ducts in mouse salivary glands. However little is known about its temporal regulation and its function in human salivary glands. Here we analysed the profile expression of several apoptosis-related proteins during human salivary gland development in correlation to each morphogenetic stage by immunohistochemistry (Bax, Bak, Bad, Bid, Bcl-2, Bclx, Bcl-xL, cleaved caspase-3, caspases-6, -7 e -9, apaf-1, survivin e citocromo c). Immunohistochemical results were analysed semi-qualitatively, and proteins Bcl-2, Bad, Bid and cleaved caspase-3 were considered completely negative at all stages of development. The nuclear expression of Bax and Bak were observed within the presumptive luminal spaces at early stages, while $\mathrm{Bcl}-\mathrm{xL}$ was the antiapoptotic factor of Bcl-2 family that showed more prominent nuclear expression. Caspases-6, -7 and 
-9 were positive at all stages, and the absence of cleaved caspase- 3 suggests caspase-7 as the main effector caspase during human salivary gland development. Both components of the apoptosome complex were also positive through all development, and the inhibitor of apoptosis survivin has shown more nuclear positivity at later stages. As the expression of apoptotic regulators was observed during human salivary gland development, functional experiments were then performed in mouse salivary gland cultures to determine the apoptotic activity of during the glandular formation. Initially, the apoptotic activity was detected in mouse salivary glands within the centre of primary epithelial stalks from early stages of development by TUNEL and cleaved caspase-3. Thus the in vitro apoptotic inhibition was performed at the same stages, which resulted in significant wider ducts and important morphological defects within luminal and acinar structures. This work has therefore evidenced the existence of apoptotic role in salivary gland lumen formation of both human and mouse models, having an earlier start point as reported before. Moreover, the absence of Bad and Bid indicates that the intrinsic pathway is more active than the extrinsic during human development, and the distinct subcellular expression of most molecules suggests additional non-apoptotic functions.

Key words: Salivary glands. Morphogenesis. Apoptosis. Caspases. 


\section{LISTA DE TABELAS}

Tabela 4.1 - Dados dos anticorpos primários utilizados no estudo em glândulas salivares humanas com respectivos clones, títulos, procedências e modo de recuperação antigênica.

Tabela 4.2 - Tempo de incubação mínimo dos espécimes animais de acordo com o estágio de desenvolvimento

Tabela 4.3 -Etapa de desidratação do processamento dos espécimes animais. .49

Tabela 4.4 -Análise semi-qualitativa do perfil de expressão de proteínas da família Bcl-2 em glândulas salivares humanas em desenvolvimento 60

Tabela 4.5-Análise semi-qualitativa do perfil de expressão de caspases em glândulas salivares humanas em desenvolvimento. 62

Tabela 4.6 -Análise semi-qualitativa de survivina, apaf-1 e citocromo c em glândulas salivares humanas em desenvolvimento 64

Tabela 5.3 - Análise semi-qualitativa da expressão do inibidor de apoptose survivina e dos membros do complexo apoptossomo Apaf-1 e citocromo C de acordo com os estágios morfogenéticos das glândulas salivares humanas. 68 


\section{LISTA DE FIGURAS}

Figura 2.1 - Ilustração esquemática da histologia das glândulas salivares 21

Figura 2.2 - Representação esquemática das fases de desenvolvimento das glândulas salivares.

Figura 2.3 - Figura esquemática representando os diversos tipos de abertura luminal durante a tubulogênese.

Figura 2.4 - Esquema representativo ilustrando as principais vias de sinalização apoptótica.

Figura 4.1 - Dissecção das glândulas salivares de fetos humanos 43

Figura 4.2 - Esquema representativo do procedimento de dissecção das glândulas salivares submandibular e sublingual de camundongo CD1

Figura 5.1 - Imagens comparativas dos estágios morfogenéticos das glândulas salivares maiores humanas e de camundongo. 55

Figura 5.2 - Expressão de proteínas pró e antiapoptóticas da família Bcl-2 durante o desenvolvimento das glândulas salivares humanas.

Figura 5.3 - Perfil de expressão de caspases efetoras e iniciadora durante o desenvolvimento das glândulas salivares humanas.

Figura 5.4 - Expressão de componentes do complexo apoptossomo e do inibidor de apoptose survivina durante o desenvolvimento das glândulas salivares humanas....... .69

Figura 5.5 - Expressão de proteínas envolvidas no mecanismo apoptótico intrínseco em ductos excretores de glândulas salivares humanas em fase tardia de desenvolvimento. 
Figura 5.6 - Comparação da expressividade de marcadores apoptóticos em glândulas submandibulares de camundongo

Figura 5.7 - Regiões correspondentes ao presuntivo espaço luminal glandular exibem importante marcação de citoqueratina 7 (K7) 75

Figura 5.8 - Alteração morfológica decorrente da inibição de caspases em fase precoce de desenvolvimento glandular..... 78

Figura 5.9 - Efeitos da inibição de caspases em glândulas salivares de camundongo em estágio pseudoglandular (E13.5) .80

Figura 5.10 - Inibição apoptótica em glândulas salivares de camundongo em estágio canalicular (E14.5).

Figura 5.11 - Localização morfológica de células com atividade apoptótica inibida durante $\mathrm{o}$ desenvolvimento de glândulas salivares em estágio pseudoglandular .84

Figura 5.12 - Expressão de caspase-3 clivada em ductos submandibulares de glândulas salivares em estágio pseudoglandular E13.5 após 20h de cultura in vitro. .85 


\section{SUMÁRIO}

1 INTRODUÇÃO

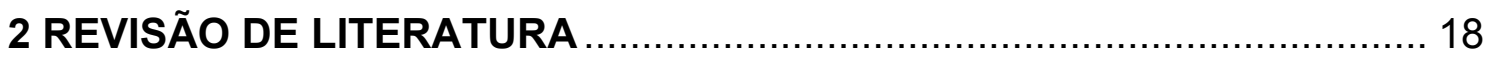

2.1 GLÂNDULAS SALIVARES: CLASSIFICAÇÃO E CARACTERÍSTICAS

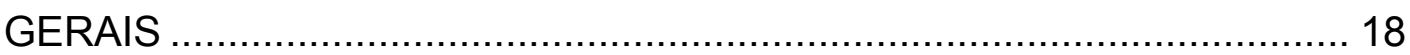

2.2 HISTOLOGIA DA ESTRUTURA GLANDULAR ................................... 19

2.3 MORFOGÊNESE DAS GLÂNDULAS SALIVARES …........................... 23

2.4 MORFOGÊNESE DOS TUBOS EPITELIAIS ............................................ 25

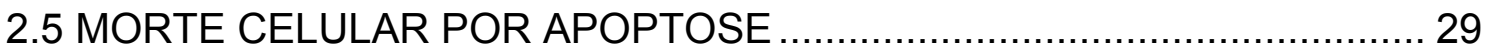

2.6 PRINCIPAIS GRUPOS MOLECULARES ENVOLVIDOS NA MODULAÇÃO

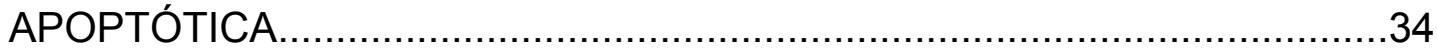

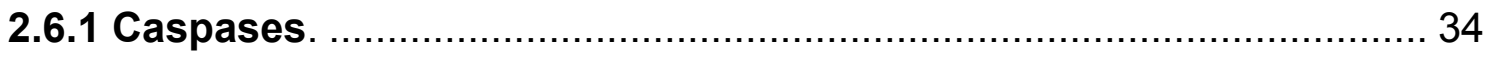

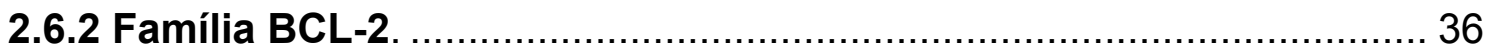

2.6.3 Proteínas Inibidoras da Apoptose ...................................................... 38

З OBJETIVOS

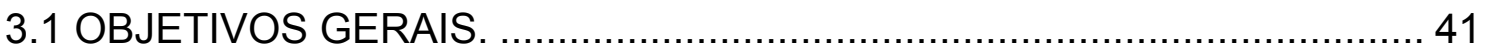

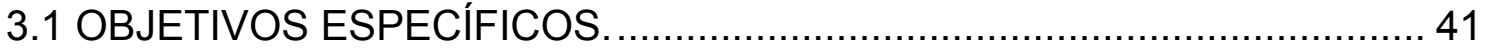

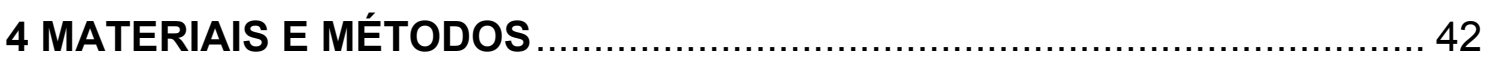

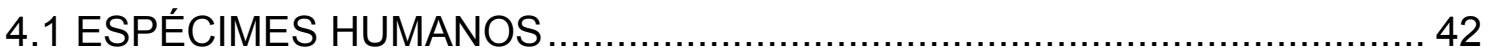

4.1.1 Obtenção dos Espécimes ................................................................. 42

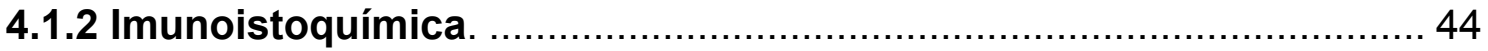




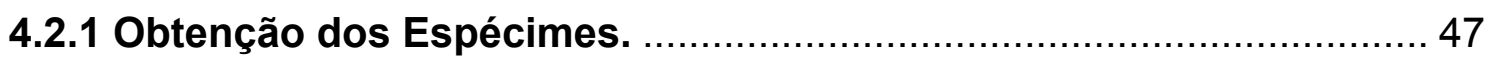

4.2.2 Processamento dos Espécimes. ................................................. 48

4.2.3 Histologia

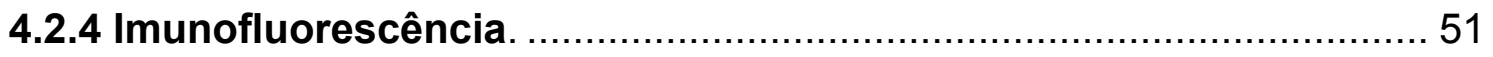

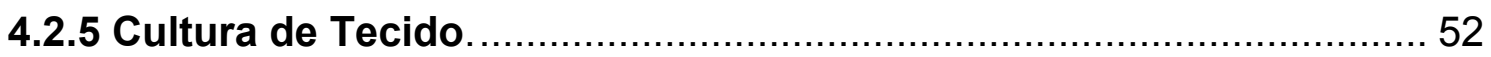

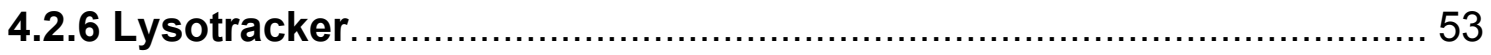

4.2.7 Análise Morfométrica das Culturas de Tecido................................ 54

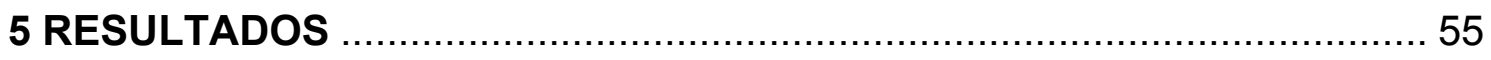

5.1 ANÁLISE MORFOLÓGICA DOS ESTÁGIOS DE DESENVOLVIMENTO

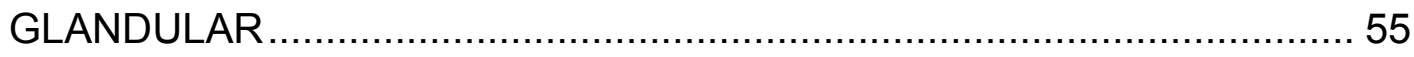

5.2 ANÁLISE SEMI-QUALITATIVA DA EXPRESSÃO DE PROTEÍNAS APOPTÓTICAS DURANTE O DESENVOLVIMENTO DAS GLÂNDULAS

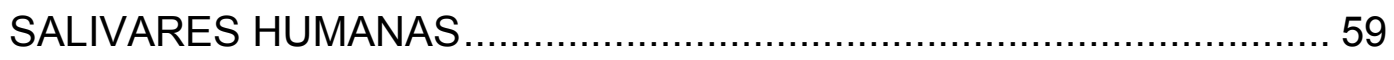

5.2.1 Resultados Imunoistoquímicos - Família Bcl-2 …........................... 60

5.2.2 Resultados Imunoistoquímicos - Caspases ................................... 64

5.2.3 Resultados Imunoistoquímicos - Apoptossomo e Survivina ........... 67

5.3 ANÁLISE MORFOLÓGICA DA ATIVIDADE APOPTÓTICA DURANTE O DESENVOLVIMENTO DE GLÂNDULAS SALIVARES DE CAMUNDONGO

5.4 ANÁLISE FUNCIONAL DA INIBIÇÃO APOPTÓTICA DURANTE O DESENVOLVIMENTO DE GLÂNDULAS SALIVARES DE

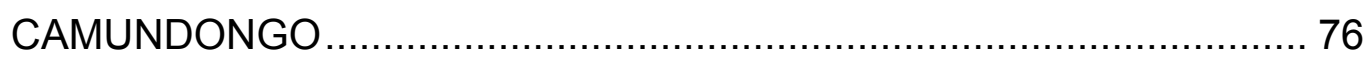

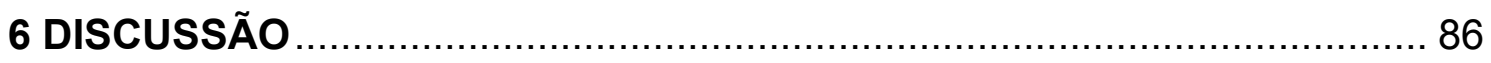

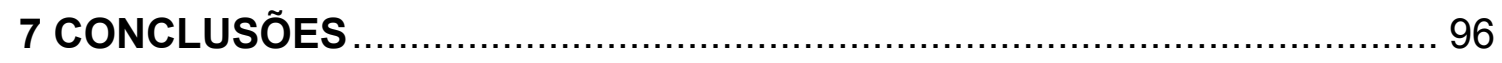


REFERÊNCIAS

98

ANEXO A - Aprovação do Comitê de Ética.

ANEXO B - Artigos Publicados. 


\section{INTRODUÇÃO}

A disfunção das glândulas salivares é a principal causa do quadro da síndrome de boca seca, cuja prevalência se eleva com a idade quando associada a outros fatores, afetando aproximadamente $30 \%$ da população com mais de 65 anos (Ship, 2002). A xerostomia caracteriza-se pela sensação subjetiva de boca seca, que geralmente resulta em dificuldades fisiológicas como fala, mastigação, deglutição, paladar, além de elevar o risco da ocorrência de infecções orais, impactando diretamente na qualidade de vida. Radioterapia de região de cabeça e pescoço, doenças inflamatórias como Síndrome de Sjögren, uso de certas medicações e desordens genéticas como a síndrome lacrimo-auriculo-dento-digital (LADD) e a aplasia de glândulas salivares e lacrimais (ALSG) são as principais causas da xerostomia, afetando substancialmente a função e o desenvolvimento das glândulas salivares. Frequentemente prejudicam o tecido glandular ou afetam qualidade da secreção de forma irreversível, e até o momento não há cura definitiva para xerostomia independentemente da causa, somente tratamentos sintomáticos (Redman, 2008). Considerando o grande número de indivíduos afetados e o potencial aumento da incidência de xerostomia em populações com crescente taxa de expectativa de vida, é fundamental investigar os mecanismos básicos de desenvolvimento glandular capazes de contribuir com conhecimentos em estratégias regenerativas que permitam restabelecer a função glandular (Hsu; Yamada, 2010; Lombaert et al., 2011).

O desenvolvimento das glândulas salivares humanas é um processo dinâmico baseado em extensa ramificação do epitélio oral que envolve crescimento, proliferação, diferenciação, migração e morte celular, exigindo uma interação dinâmica e recíproca entre diferentes tipos de tecido (Melnick; Jaskoll, 2000; Patel et al., 2011; Patel el al., 2006). A adequada formação do sistema ductal e das unidades secretoras terminais é fundamental para a síntese e distribuição do fluido salivar, componente que protege a cavidade oral de injúrias mecânicas através da lubrificação, e que fornece suprimentos eletrolíticos, mucosos e antibacterianos 
essenciais para a manutenção da saúde oral e da qualidade de vida (Hsu; Yamada, 2010; Szlávik et al., 2008; Tucker; Miletitch, 2010).

A formação do espaço luminal no interior de cordões sólidos epiteliais é essencial para construir um sistema funcional de ductos em diferentes órgãos como glândulas mamárias e salivares (Kwon; Larsen, 2015; Mailleux et al., 2007). Sugerese que a canalização ductal das glândulas salivares ocorre com a eliminação de células no interior dos cordões epiteliais por apoptose, um mecanismo programado de morte celular, criando o espaço luminal secundariamente à morfogênese glandular inicial (Andrew; Ewald, 2010; Lubarsky; Krasnow, 2003). A presença de células apoptóticas durante a formação de glândulas salivares em modelos animais já foi observada (Melnick et al., 2001), entretanto a regulação temporal da apoptose é pouco explorada na literatura, principalmente em humanos, e o requerimento de sua função durante o desenvolvimento das glândulas salivares tem sido discutido recentemente (Nedvetsky et al., 2014). Baseados nessas evidências, o presente estudo justifica-se para tentar responder as seguintes indagações:

- Relata-se que o mecanismo intrínseco da apoptose está mais associado a processos de desenvolvimento de diversos órgãos em mamíferos em comparação com o extrínseco. Similarmente, a apoptose também está presente em glândulas salivares humanas em desenvolvimento?

- Qual o padrão de expressão morfológico e temporal de marcadores apoptóticos intrínsecos e em quais fases do processo de desenvolvimento das glândulas salivares humanas são encontrados?

- Como consequência da morfogênese, a apoptose é requerida para a abertura dos espaços luminais do sistema de ductos das glândulas salivares? 


\section{REVISÃO DE LITERATURA}

\subsection{GLÂNDULAS SALIVARES: CLASSIFICAÇÃO E CARACTERÍSTICAS GERAIS}

As glândulas salivares são estruturas fundamentais na síntese e secreção do fluido salivar, sendo, portanto caracterizadas como órgãos exócrinos e constituídas essencialmente por uma porção secretora diferenciada e por um sistema de ductos que modifica e conduz a saliva à cavidade oral. Distribuídas por toda a região submucosa oral como palato, língua, mucosa jugal e mucosa labial, encontram-se inúmeras glândulas salivares menores, responsáveis por somente $10 \%$ da secreção salivar (Humphrey; Williamson, 2001; Ten Cate, 2001). As glândulas maiores, por sua vez, se dispõem em pares e são representadas pelas sublinguais, submandibulares e parótidas. Juntas, as glândulas salivares maiores e menores produzem uma grande quantidade de saliva diariamente, em torno de 1000 a 2000 mL/d (Junqueira; Carneiro, 2004; Wong, 2008). As glândulas são classificadas como serosas (parótida), mucosas (menores, com exceção da glândula serosa de Von Ebner) ou seromucosas (submandibular e sublingual), na dependência de sua estrutura e do tipo de secreção (Junqueira; Carneiro, 2004).

Basicamente, a glândula salivar é composta por um parênquima, que exerce o papel funcional, e por um estroma, o qual exibe um tecido conjuntivo de suporte que constitui a cápsula mesenquimal que envolve a glândula e os septos que separam os lóbulos glandulares. As unidades secretoras terminais dispostas no componente parenquimatoso são formadas por células acinares diferenciadas que produzem e liberam seu conteúdo no interior do sistema de ductos, atingindo a cavidade oral através dos ductos intercalar, estriado e excretor. O tipo de unidade terminal determina a característica da secreção salivar, sendo as células mucosas responsáveis pela produção de uma saliva viscosa e repleta de glicoproteínas, enquanto as serosas dão origem a uma saliva aquosa e fluida (Junqueira; Carneiro, 2004; Tucker; Miletitch, 2010).

Uma adequada secreção salivar é extremamente importante para a manutenção da saúde bucal devido às diversas propriedades químicas e mecânicas do fluido 
salivar, cuja principal função é proteger a superfície mucosa e as estruturas dentárias. A saliva é também essencial para lubrificar a mucosa oral, o bolo alimentar e as superfícies dentárias, facilitando a mastigação e deglutição principalmente devido à presença de mucinas, água e outras glicoproteínas (Tabak et al., 1982). A quantidade de componentes eletrolíticos no fluido salivar como fluoreto e cálcio é imprescindível para equilibrar o $\mathrm{pH}$ da cavidade oral por criar um reservatório mineral que mantém a homeostase e evita a desmineralização da superfície dentária (Schneyer; Schneyer, 1967). Sua atuação como solvente de substâncias gustatórias ao redor dos receptores permite uma melhor percepção gustativa por interagir e estimular continuamente a sensibilidade gustatória (Matsuo, 2000). A presença de imunoglobulinas, lisozima e lactoperoxidase conferem ao fluido salivar um importante potencial antimicrobiano (Fábián et al., 2012), além de possuir atividade digestória através das enzimas lipase e $\alpha$-amilase que promovem os primeiros estágios digestórios ainda na cavidade oral (Pedersen et al., 2002). Alguns estudos já demonstraram atividade citoprotetora dos fatores de crescimento presentes no fluido salivar, contribuindo para a recuperação e manutenção da integridade da mucosa bucal (Noguchi et al., 1991; Azuma et al., 2015).

Disfunções relacionadas à perda ou redução da secreção salivar como relatadas em doenças sistêmicas como Síndrome de Sjögren e diabetes tipo 1 e 2, em situações pós-radioterapia em região de cabeça e pescoço, uso de determinados medicamentos (Mata et al., 2004; Delli et al., 2014), desordens genéticas com aplasia glandular como a síndrome lacrimo-auriculo-dento-digital (LADD) e a aplasia de glândulas salivares e lacrimais (ALSG) (Wiedemann; Drescher, 1986; Milunsky et al., 2006), ilustram a importância de sua presença na cavidade oral, uma vez que frequentemente ocasionam infecções, processos cariosos, dificuldades de mastigação e deglutição, perda de paladar, dor e desconforto (Hsu; Yamada, 2010; Tucker; Miletitch, 2010).

\subsection{HISTOLOGIA DA ESTRUTURA GLANDULAR}

A estrutura morfofuncional das glândulas salivares é denominada adenômero, constituída de unidades secretoras funcionais conectadas a um sistema de ductos 
que modifica e conduz a saliva à cavidade oral (Figura 2.1) (Katchburian; Arana, 2004). A porção funcional é constituída de células estruturalmente distintas, que resulta em tipos diferentes de secreção. As células secretoras terminais do tipo seroso apresentam-se como estruturas piramidais dispostas em grupos concêntricos chamados ácinos, que exibem um núcleo grande arredondado e pequenos grânulos basofílicos na região apical. A base mais extensa da célula encontra-se voltada para a lâmina própria, na região basal, enquanto microvilos pequenos e irregulares podem ser observados na membrana apical da célula acinar (Figura 2.1 - ácino seroso). Por outro lado, as células mucosas secretam um fluido salivar de conteúdo mucoso, caracterizando uma saliva mais espessa e importante para a lubrificação da cavidade oral. Tais células apresentam forma colunar com núcleo achatado e deslocado para a porção basal devido ao acúmulo de grânulos mucosos nos terços apicais, sendo organizadas em grupamentos tubulares alongados (Figura 2.1 ácino mucoso). Estruturas contráteis conhecidas como células mioepiteliais envolvem as unidades secretoras terminais e os ductos menores proximais, auxiliando na liberação da secreção granular e elevando a fluxo salivar (Figura 2.1 célula mioepitelial) (Junqueira; Carneiro, 2004; Tucker; Miletitch, 2010).

A produção salivar constitui primariamente um fluido isotônico em relação ao plasma, que precisa tornar-se hipotônica antes de atingir a cavidade oral para executar suas funções apropriadamente. Para tanto, o sistema de ductos atua como um regulador eletrolítico, reabsorvendo o sódio $\left(\mathrm{Na}^{+}\right)$e cloreto $\left(\mathrm{Cl}^{-}\right)$da secreção primária durante sua passagem pelos diferentes tipos de ducto (Humphrey; Williamson, 2001). Sua classificação baseia-se em função e estrutura, sendo agrupados em ductos intercalares, estriados e excretores, que são gradualmente mais calibrosos ao seu término na cavidade oral. Os ductos intercalares estão em contato com as unidades funcionais, sendo os primeiros a receber a secreção salivar; são caracteristicamente constituídos de pequenas células epiteliais cuboidais (Figura 2.1 - ducto intercalar). Esses pequenos ductos dão origem aos ductos estriados, os quais apresentam diversas estrias em sua porção basal provenientes de uma intensa invaginação da membrana plasmática local e da presença de inúmeras mitocôndrias verticais. Essas organelas oferecem o suporte energético necessário para que esses ductos exerçam sua função primordial de executar a troca iônica do conteúdo salivar com o estroma, caracterizando a hipotonicidade da 
saliva neste estágio (Junqueira; Carneiro, 2004; Tucker; Miletitch, 2010; Wong, 2008). Para finalmente atingir a cavidade oral, o fluido salivar passa pelos ductos excretores, constituídos de um epitélio estratificado de células cuboidais (Figura 2.1 - ductos excretores) (Wong, 2008). Portanto, o sistema de ductos das glândulas salivares é responsável não somente pelo transporte do fluido salivar proveniente da secreção das diferentes unidades secretoras terminais até a cavidade oral, mas também pela troca iônica necessária para executar suas funções.

As glândulas salivares de mamíferos assemelham-se muito na secreção dos produtos finais e na morfologia de seus componentes. Por conta disso, o modelo animal é amplamente utilizado em pesquisas comparativas e principalmente em experimentos funcionais para elucidar seus mecanismos de desenvolvimento. As principais diferenças observadas entre glândulas salivares de humanos e roedores encontram-se na submandibular, em que roedores não exibem o componente mucoso (representa aproximadamente 10 a $20 \%$ em humanos), ao passo que apresentam um ducto adicional conhecido como ducto granular ou convoluto, localizado entre ductos intercalados e estriados. A secreção desse ducto é essencialmente de enzimas e fatores de crescimento, atividade realizada pelos ductos estriados em humanos (Gresik, 1994; Tucker; Miletitch, 2010; Amano et al., 2012). 


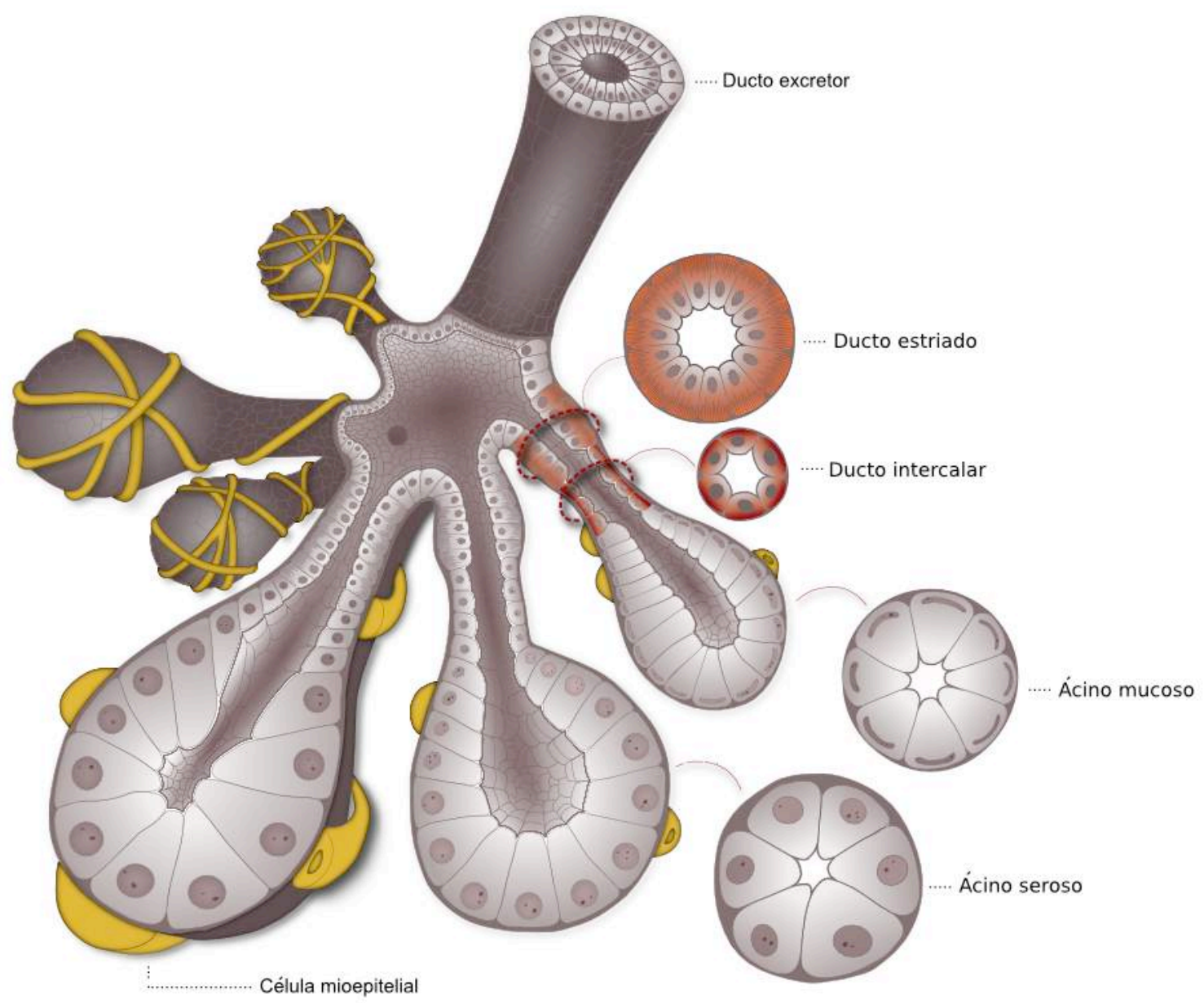

Figura 2.1 - Ilustração esquemática da histologia das glândulas salivares

A estrutura celular do sistema de ductos varia entre os diferentes tipos ductais (intercalar, estriado, excretor). Observa-se também a diferença do padrão celular entre as porções terminais secretoras serosa e mucosa, associadas a células mioepiteliais. 


\subsection{MORFOGÊNESE DAS GLÂNDULAS SALIVARES}

O conhecimento acerca da formação das glândulas salivares é proveniente de diversos estudos feitos em modelos animais como Drosophila, ratos e camundongos, que demonstraram semelhanças nos mecanismos de desenvolvimento (Cutler; Gremski, 1991; Melnick; Jaskoll, 2000; Andrew et al., 2000; Tucker, 2007). Similarmente, as glândulas salivares humanas compartilham desses processos celulares, de maneira que são regulados por fatores intrínsecos e extrínsecos que determinam a morfogênese, a proliferação e a diferenciação celular durante esse processo (Cutler, 1990; Denny et al., 1997; Hsu; Yamada, 2010; lanez et al., 2010). Os fatores intrínsecos são definidos como características préprogramadas da expressão genética específica de cada tipo celular, enquanto os extrínsecos são sinais produzidos por citocinas e fatores de crescimento do meio extracelular e pela interação célula-célula e célula-matriz-extracelular (Denny et al, 1997; Melnick; Jaskoll, 2000; Loreto et al., 2010).

Apesar de temporalmente distintas, as estruturas encontradas durante a morfogênese das glândulas salivares humanas são muito semelhantes às observadas no desenvolvimento glandular de modelos animais, sendo portanto classificadas da mesma maneira como já relatado anteriormente (Lourenço et al., 2007, 2008; Teshima et al., 2011). As primeiras observações dos estágios de desenvolvimento ocorreram por volta de 1950, em que culturas in vitro de glândulas salivares de camundongo foram demonstradas (Borghese, 1950). Atualmente, o processo é dividido em cinco fases: pré-botão, botão inicial, pseudoglandular, canalicular e botão terminal (Melnick; Jaskoll, 2000; Tucker, 2007). A fase de prébotão é caracterizada somente pelo espessamento do epitélio primitivo oral, que posteriormente prolifera-se em direção ao mesênquima subjacente formando estruturas celulares chamadas botões e compõe a fase de botão inicial. De maneira contínua, esses botões epiteliais continuam a proliferar intensamente de forma a originar cordões majoritariamente sólidos, que se ramificam através da presença de fendas formadas inicialmente na região dos botões, constituindo a fase pseudoglandular. A seguir, a fase canalicular já exibe cordões celulares maiores e mais ramificados com um espaço luminal bem estabelecido. A formação e diferenciação dos ductos excretores finais e das unidades secretoras finalizam o 
processo com a fase terminal de botão (Figura 2.2) (Melnick; Jaskoll, 2000; Tucker, 2007; Lourenço et al., 2008; Teshima et al., 2011).

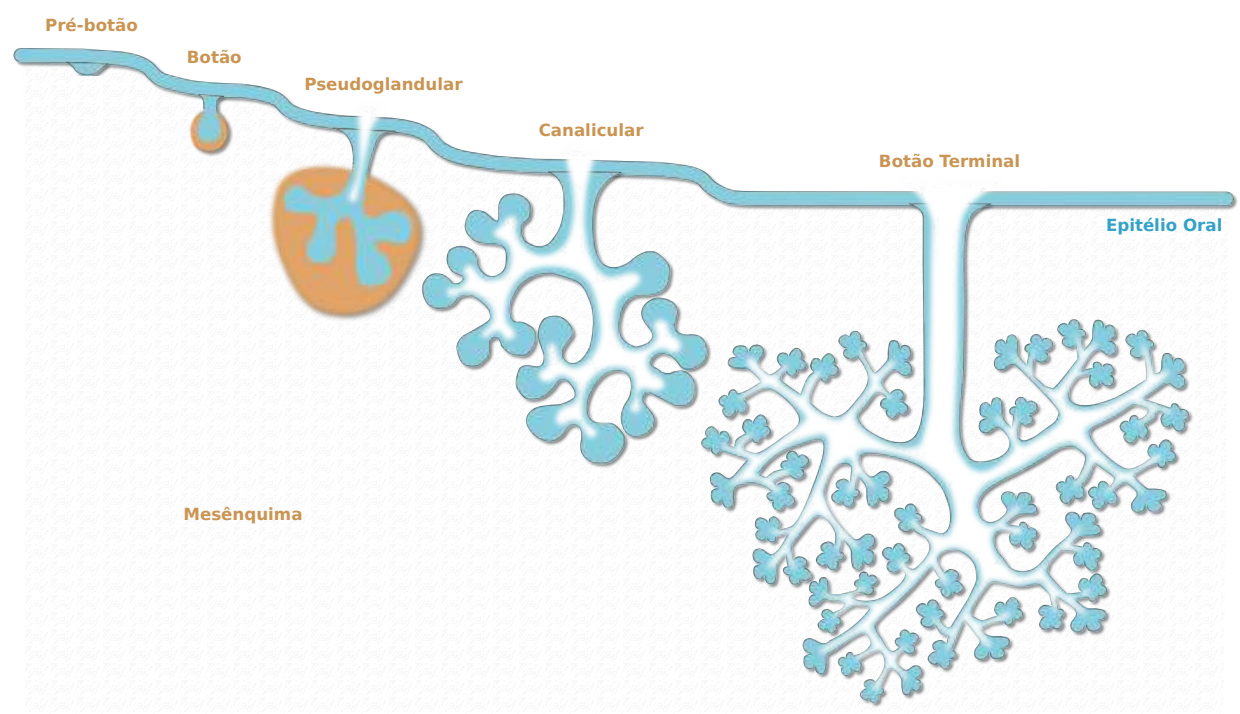

Figura 2.2 - Representação esquemática das fases de desenvolvimento das glândulas salivares

A fase de pré-botão é a fase inicial em que ocorre o espessamento do epitélio oral (azul) em direção ao mesênquima subjacente. $\mathrm{Na}$ fase de botão observa-se a formação de ilhas epiteliais sólidas circundadas por um mesênquima condensado, essencial para a sinalização celular. A seguir, o estágio pseudoglandular passa a exibir múltiplos botões epiteliais ramificados e conectados ao cordão epitelial principal, em que já se observa o rudimento do futuro espaço luminal. Ductos mais maduros e com abertura luminal evidente são encontrados a partir da fase canalicular, e as estruturas terminais secretoras finalizam sua diferenciação acinar na fase de botão terminal. 


\subsection{MORFOGÊNESE DE TUBOS EPITELIAIS}

A presença de uma organização tubular nos diferentes tecidos glandulares é essencial para a homeostasia de diversos órgãos como rins, pulmões, sistema vascular, trato digestório e glândulas exócrinas, que se desenvolvem por meio de uma série de mecanismos complexos como alteração de morfologia, migração e adesão celular. Através do sistema de tubos, promovem-se importantes funções fisiológicas como síntese e distribuição de nutrientes, enzimas, restos teciduais e hormônios produzidos pela glândula (Chung; Andrew, 2008; Iruela-Arispe; Beitel, 2013). Considerando tal importância, diversos sistemas em vertebrados e invertebrados têm sido estudados para elucidar os diversos eventos celulares e moleculares necessários para promover a abertura desses tubos funcionais.

A formação de tubos baseia-se essencialmente em cinco maneiras diferentes a depender do órgão envolvido, podendo apresentar alterações na forma celular, alterações no citoesqueleto e/ou envolver outros mecanismos como morte celular. Epitélios polarizados que possuem domínios celulares basolateral e apical definidos originam o sistema de tubos por dois mecanismos denominados envelopamento (wrapping ) ou brotamento (budding). Esse processo exige somente uma mudança na forma e/ou organização celular. Por outro lado, epitélios despolarizados recebem primeiramente um sinal para definir a polaridade apicobasal para depois seguirem com o processo de cavitação, esvaziamento celular ou esvaziamento dos cordões celulares (Figura 2.3A, B) (Lubarsky; Krasnow, 2003; Andrew; Ewald, 2010).

As duas vias de formação tubular em epitélios polarizados são semelhantes, em que ambas sofrem uma constrição apical coordenada por mecanismos moleculares específicos na lâmina epitelial, de maneira que ocorra a invaginação das células envolvidas em direção ao ectomesênquima subjacente. Na via conhecida como envelopamento, essa invaginação continua até que as extremidades da lâmina se encontrem e formem a estrutura tubular que termine paralelamente ao plano do epitélio original, podendo ser independente ou não, como é observado na formação do tubo neural em diversos vertebrados (Colas; Schoenwolf, 2001) (Figura 2.3A). Por outro lado, a via de brotamento epitelial dá origem a um tubo que permanece ligado ortogonalmente ao epitélio de origem, 
ocorrendo através de constrição apical, recrutamento, divisão e/ou alongamento celular (Figura 2.3B). Esse segundo mecanismo foi caracterizado durante a formação de importantes órgãos como traqueia e glândulas salivares de $D$. melanogaster e pulmões de mamíferos (Ghabrial; Krasnow, 2006; Kerman et al., 2006; Metzger et al., 2008). A polaridade e integridade do primórdio epitelial são mantidas durante ambos os processos, e o espaço luminal é apenas uma consequência do movimento celular.

A morfogênese dos tubos a partir de tecidos não polarizados, por sua vez, pode ocorrer por mecanismos conhecidos como esvaziamento celular (cell hollowing), esvaziamento dos cordões celulares (cord hollowing) ou cavitação (cavitation) (Figura 2.3C, D, E, respectivamente). O esvaziamento celular consiste na formação do lúmen através da coalescência da membrana apical de pequenas vesículas citoplasmáticas intracelulares, de maneira a conectar o lúmen distal ao mesial ao longo de cada célula do tubo (Figura 2.3C). A ocorrência desse processo é característica em cilindros epiteliais estreitos de pequeno calibre, como observados durante o desenvolvimento endotelial in vivo e in vitro (Kamei et al., 2006). Alternativamente, tubos multicelulares de grande calibre caracteristicamente sólidos são formados por esvaziamento de cordão ou cavitação, os quais teoricamente diferenciam-se pela perda ou não de elementos celulares por morte celular programada (Figura 2.3D, E). A formação de junções intercelulares e a aquisição de polaridade apicobasal concomitantemente ao surgimento do lúmen caracteriza a tubulogênese por esvaziamento de cordão celular, ocorrendo em regiões de contato da membrana apical das células epiteliais, sem haver perda celular. De maneira semelhante, a formação do lúmen por cavitação também se baseia na polarização das células periféricas, porém adicionalmente requere a remoção das células centrais por apoptose para a adequada abertura luminal, que também atua na manutenção desse espaço interno para a correta funcionalidade glandular (Lubarsky; Krasnow, 2003; Chung; Andrew, 2008). Estudos sobre a formação das glândulas salivares embrionárias de camundongo, cavidade próamniótica de vertebrados e em cultura in vitro de glândulas mamárias já demonstraram a ocorrência de morte celular programada durante a abertura luminal (Coucouvanis; Martin, 1995; Debnath et al., 2002; Melnick; Jaskoll, 2000). Sugere-se também que o processo de cavitação pode ser um tipo especial de esvaziamento de 
cordão celular, exigindo um passo adicional de remoção celular para a abertura do lúmen, especialmente quando há falha ou retardo na polarização celular (Grossmann, 2002; Andrew; Ewald, 2010;). 
A

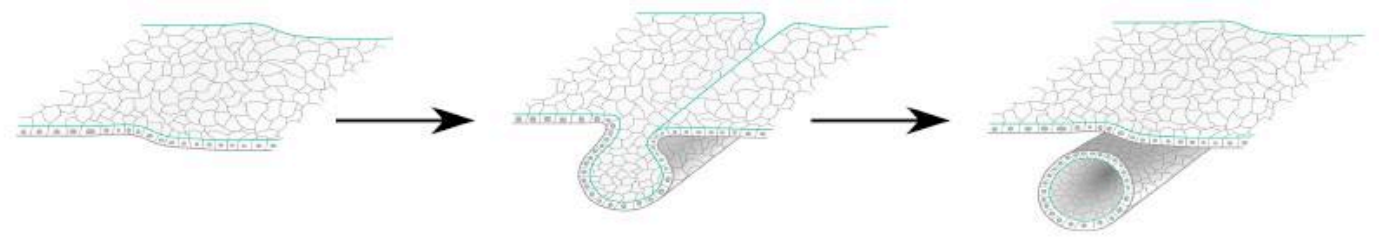

B

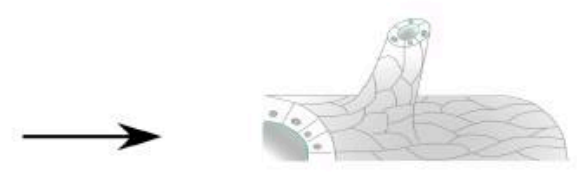

C
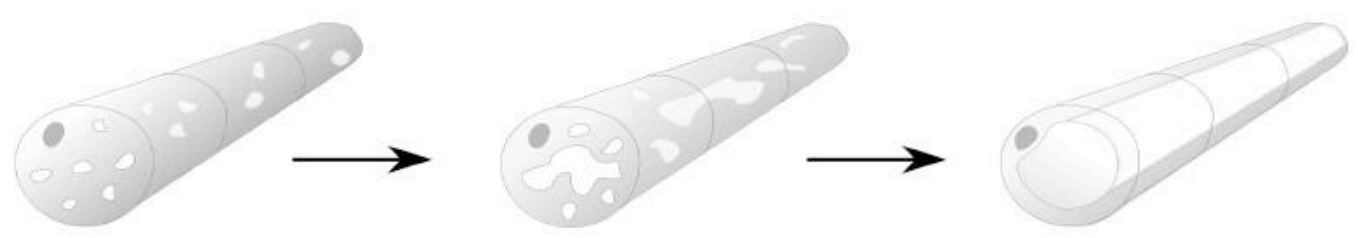

D
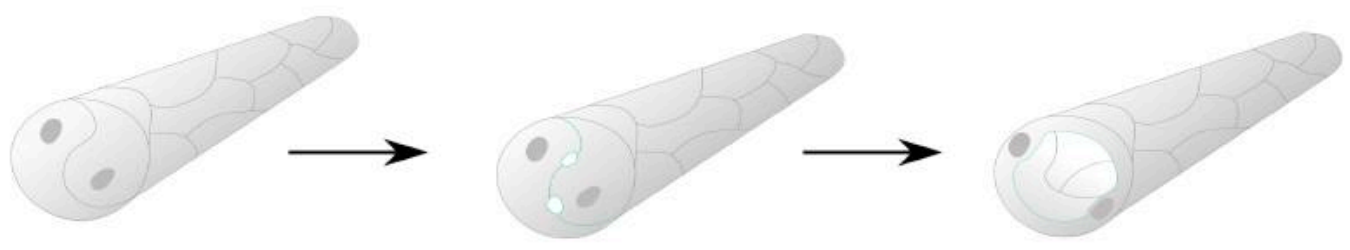

E
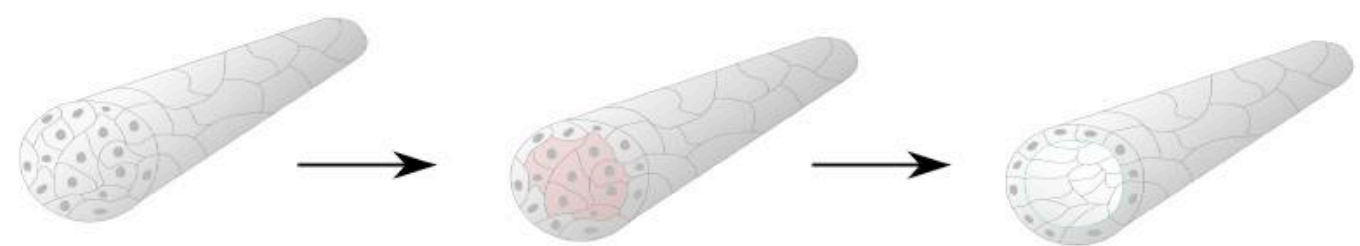

Figura 2.3 - Figura esquemática representando os diversos tipos de abertura luminal durante a tubulogênese

(A, B) formação tubular em tecidos polarizados por constrição apical da estrutura invaginada, circundando o espaço luminal. Pelo mecanismo de envelopamento (wrapping), o tubo formado desconecta-se completamente do tecido de origem (A), enquanto por brotamento (budding) o sistema tubular mantém-se ligado ortogonalmente ao tecido original (B). (C, D, E) tubulogênese em tecidos nãopolarizados ou células isoladas promovem a abertura luminal através de diferentes mecanismos. Vacúolos intracitoplasmáticos em cordões celulares estreitos fusionam-se e formam o lúmen por esvaziamento celular (cell hollowing)(C), ao passo que cordões sólidos mais espessos exibem abertura do lúmen inicialmente através da polarização celular. A reorganização celular ao redor da área luminal determinada ocorre por esvaziamento de cordão (cord hollowing)(D) ou cavitação (cavitation) na presença de apoptose das células centrais $(E)$. 


\subsection{MORTE CELULAR POR APOPTOSE}

Apoptose é um termo criado por Kerr, Wyllie e Currie que se fundamenta na morte celular programada, um dos mecanismos fisiológicos endógenos de morte celular que promove a eliminação de células sem função ou prejudiciais ao organismo (Kerr et al., 1972; Elmore, 2007). Inicialmente o processo era referido como necrobiose, uma forma de morte celular programada fisiológica, que, sem dúvida, equilibrava a atividade proliferativa em diversos tecidos normais, de modo a controlar a população celular. A investigação dos mecanismos envolvidos nesse processo originou-se em estudos em invertebrados (C. elegans), nos quais observou-se invariável celular nos adultos, exibindo períodos específicos de ativação geneticamente controlada durante seu desenvolvimento (Ellis; Horvitz, 1986). Assim, os aspectos morfológicos e moleculares envolvidos na apoptose foram progressivamente elucidados e mostraram-se cada vez mais específicos e correlacionados com importantes mecanismos fisiológicos e patológicos, reconhecendo-se portanto o termo apoptose como uma nova entidade de eliminação celular. Além da manutenção da homeostase e de tecidos adultos, relata-se que a atividade apoptótica durante o processo normal de embriogênese apresenta uma função regulatória fundamental específica para determinados mecanismos como a abertura luminal de tubos glandulares, modelagem de membros e formação das fendas interdigitais. O descontrole dos mecanismos apoptóticos por sua vez pode resultar em disfunções fatais ao organismo como doenças neurodegenerativas, processos neoplásicos e doenças autoimunes (Kerr et al., 1972; Nikitakis et al., 2004; Ulukaya et al., 2011).

A morfologia de uma célula apoptótica é bastante peculiar e geralmente é observada em unidades celulares dispersas e focais por microscopia eletrônica e de luz. Durante o início do processo, a célula sofre um encolhimento caracterizado por cromatina nuclear condensada (picnose), citoplasma denso e organelas intactas firmemente compactadas em seu interior. Essa retração promove a perda de sua aderência com células vizinhas e com a matriz extracelular, que é seguida da fragmentação do núcleo e formação de diversos prolongamentos oriundos da membrana celular (membrane blebs) ocasionados pelo efluxo de colágeno e pela hidrolise da esfingomielina incorporada na membrana plasmática. Formam-se então 
os corpos apoptóticos, estruturas repletas de conteúdo celular variável que serão fagocitados. As alterações morfológicas durante a apoptose não desencadeiam reações inflamatórias por não ocorrer liberação do conteúdo celular no interstício e por haver uma rápida fagocitose sem a produção de citocinas anti-inflamatórias, representando a principal diferença observada em comparação com o processo de morte celular por necrose (Kerr et al., 1972; Elmore, 2007; Ulukaya et al., 2011). A expressão de receptores de membrana em células apoptóticas é a principal alteração bioquímica que resulta em rápida fagocitose por células adjacentes com mínimo prejuízo do tecido circunjacente. Isso ocorre geralmente pela externalização do componente lipídico de membrana fosfatidilserina (PS) ou pela exposição de proteínas como a anexina e calreticulina, sendo portanto também considerados como marcadores apoptóticos (Arur et al., 2003; Gardai et al., 2005).

Os mecanismos moleculares apoptóticos são precisamente coordenados e envolvem complexas cascatas ATP dependentes. Através de diferentes estímulos e sob o controle de diversas proteínas anti e pró-apoptóticas, as principais vias de ativação da morte celular apoptótica são classificadas como intrínseca e extrínseca (Figura 2.4). Interações mediadas por receptores de membrana da família do fator de necrose tumoral (TNFR) representam o início da ativação apoptótica do tipo extrínseca, sendo também conhecida como via do receptor de morte celular. Tais receptores possuem um domínio extracelular rico em cisteína e um citoplasmático chamado de domínio de morte (death domain), o qual desempenha uma importante função de transmitir um sinal de morte da superfície celular para a via de sinalização intracelular. Além do fator de necrose tumoral, diversas moléculas são capazes de induzir a ativação dessa mesma via, como espécies reativas de oxigênio e peróxido de hidrogênio, porém cada ligante desencadeia eventos moleculares diferentes (Rincheval et al., 2012). Desse modo, a partir do reconhecimento de um ligante específico, ocorre a formação de um complexo de sinalização de morte (deathinducing signaling complex) formado pelos domínios de morte FADD ou MORT-1 e/ou TRADD com outros componentes. A ativação de importantes enzimas apoptóticas (caspase-8 ou -10) através desse complexo será propagada para as proteases executoras (caspases-3, -6 ou -7), que promovem de fato a morte celular (Elmore, 2007; Lafont et al., 2010; Shalini et al., 2014; Belizário et al., 2015). 
A via apoptótica intrínseca é a mais comum especialmente durante o desenvolvimento e independe de estímulos extracelulares. Atua principalmente através de alterações mitocondriais estimuladas por sinais de estresse intracelular como danos no DNA, hipóxia, ativação de oncogenes e deprivação de fatores de crescimento. A mitocôndria é a organela de ação central dessa via, por meio de modificações estruturais e funcionais, agindo através da liberação de diversas moléculas pró-apoptóticas presentes em seu interior para o citoplasma e por isso é também denominada via mitocondrial (Elmore, 2007; Tait; Green, 2010; Rincheval et al., 2012). Além disso, a indução do colapso do potencial de membrana mitocondrial interna e a transição da sua permeabilidade, importantes para a ruptura da organela, também levam à perda da hemostasia celular, ocasionando a interrupção da síntese de ATP e o aumento de espécies reativas de oxigênio (EROS - induzem a ativação de caspases -9 e -3). Dessa maneira ocorre a liberação do citocromo $c$ do espaço intramembranoso mitocondrial para o citosol, onde irá ocorrer a formação de um complexo chamado apoptossomo ao ligar-se com o fator 1 de ativação da protease apoptótica (Apaf-1) e recruta e dimeriza a caspase iniciadora denominada prócaspase-9. Ao tornar-se caspase-9, a caspase-3 e -7 são por sua vez ativadas e promove-se irreversivelmente o mecanismo apoptótico com as devidas alterações celulares (Lakhani et al., 2006). Alguns estudos mostram, ainda, a participação de uma flavoproteína conhecida como fator indutor da apoptose (AIF) que, juntamente com a endonuclease $\mathrm{G}$ e CAD, promove a morte celular programada através da fragmentação do DNA e da condensação de cromatina de maneira independente às caspases em determinados tipos celulares (Elmore, 2007; Wang et al., 2012).

Apesar de serem independentes e estimuladas por mecanismos diferentes, relata-se que existe uma correlação entre as duas vias apoptóticas, havendo influência de uma via sobre a outra que amplifica o sinal apoptótico. A mudança de permeabilidade da membrana mitocondrial que consequentemente libera seu potencial pró-apoptótico no citoplasma, marcadamente como mecanismo intrínseco, pode também ocorrer com a clivagem da proteína Bid por caspase-8 através de ligações extracelulares aos receptores de membrana (Li et al., 1998). Ambas as vias levam à fase final da apoptose designada como fase de execução, que se caracteriza pela ativação das caspases efetoras, seguida da degradação de proteínas nucleares e citoesqueléticas para formar os corpos apoptóticos. A caspase 
efetora mais envolvida é a caspase-3, que ativa especificamente a endonuclease CAD através da clivagem de ICAD (inibidora de CAD), que então degrada o DNA cromossomal e causa a condensação da cromatina, além de induzir a reorganização do citoesqueleto e a desintegração da célula em corpos apoptóticos (Elmore, 2007). 


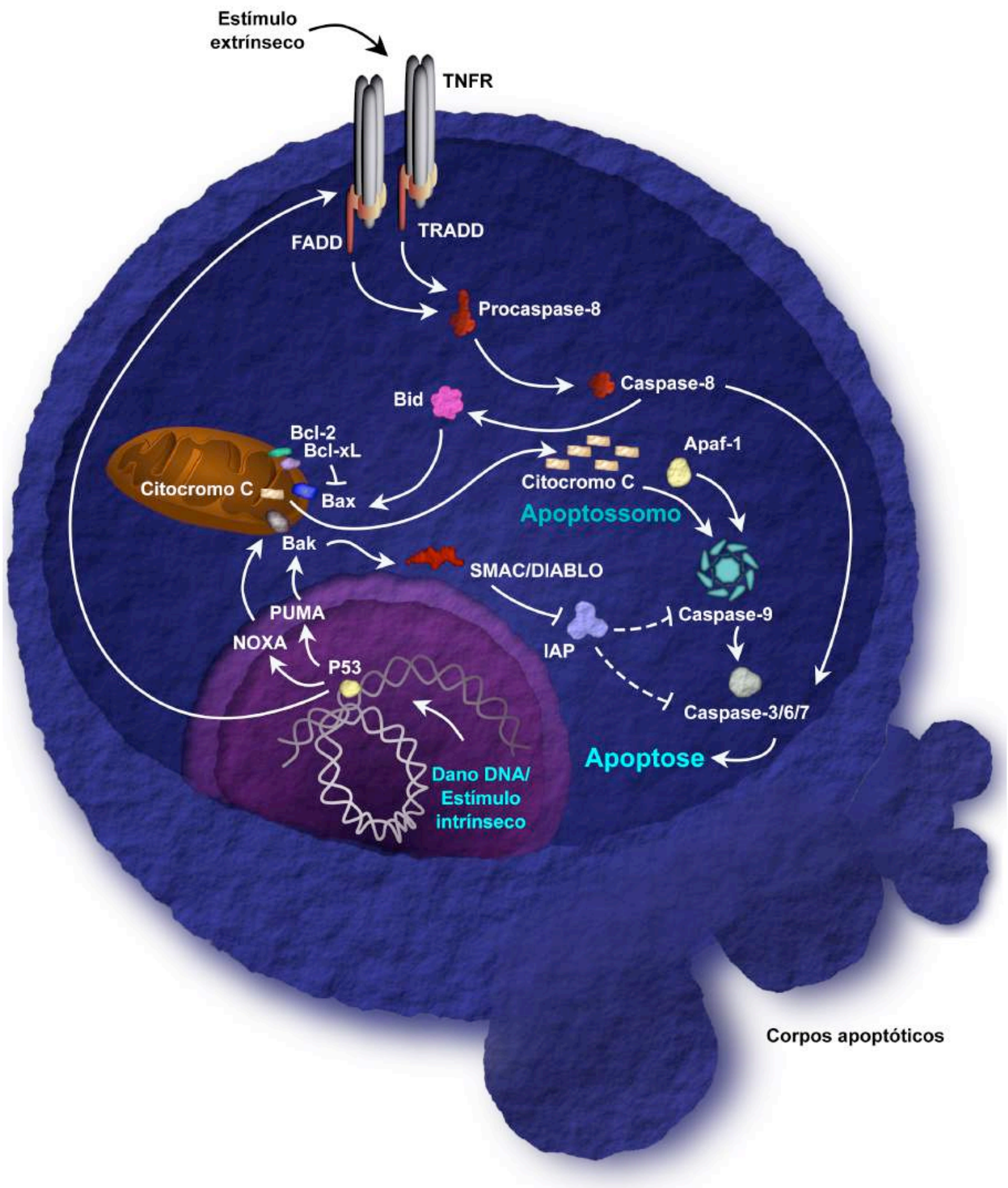

Figura 2.4 - Esquema representativo ilustrando as principais vias de sinalização apoptótica

A via intrínseca é fundamentalmente mediada por atividade mitocondrial após receber estímulo intrínseco proveniente do núcleo ou através da ativação extrínseca associada com caspase-8/Bid. 0 balanço positivo de membros pro/antiapoptóticos da família Bcl-2 (representados no esquema por $\mathrm{Bax}, \mathrm{Bad}, \mathrm{Bcl}-2$, Bcl-xL) localizados na membrana mitocondrial regulam a liberação de citocromo $\mathrm{c}$ no citoplasma, que forma o complexo apoptossomo ao se ligar a caspase-9 e Apaf-1. A via extrínseca por sua vez é dependente da ativação dos receptores de membrana TNFR, que acionam a cascata apoptótica intracelular dependente da atividade de caspases. 


\subsection{PRINCIPAIS GRUPOS MOLECULARES ENVOLVIDOS NA MODULAÇÃO APOPTÓTICA}

\subsubsection{Caspases}

As caspases ("cysteine-dependent aspartate-specific proteases") constituem uma grande família de cisteínas proteases que apresentam a função primordial de modular a apoptose. Os primeiros relatos correlacionando a função das caspases com o processo de morte celular ocorreram há mais de duas décadas em estudo do desenvolvimento do nematodo Caenorhabditis elegans com a descoberta de ced-3. Foi relatada como uma enzima que cliva o precursor de uma citocina inflamatória, a pró-interleucina $1 \beta$, sendo nomeada como "interleukin-1 $\beta$-converting enzyme" (ICE). Posteriormente, suas funções também foram relacionadas à execução da apoptose e observou-se a existência de moléculas homólogas a ced-3 em mamíferos, sendo então denominadas caspases (Yuan et al., 1993). Até o momento, relata-se a existência de aproximadamente 18 caspases em mamíferos, as quais são correlacionadas com a atividade apoptótica e inflamatória. As caspases apoptóticas são classificadas como iniciadoras (caspases-2, -8, -9, -10, -12) ou efetoras (caspases-3, -6, -7) de acordo com a presença ou ausência de domínio de interação proteica, a saber domínio efetor de morte $(D E D)$ ou domínio de recrutamento de caspases (CARD). Tais domínios são essenciais para mediar e facilitar os principais mecanismos de ativação de seus precursores chamados zimógenos ou prócaspases (Danial; Korsmeyer, 2004; Shalini et al., 2014).

Usualmente as caspases são encontradas em sua forma inativa em células normais saudáveis, com pouca ou nenhuma atividade proteásica. A ativação das caspases em mamíferos pode ocorrer por pelo menos três diferentes mecanismos (Nicholson, 1999; Hengartner, 2000; Degterev et al., 2003):

a. por recrutamento, pró-enzimas homólogas são atraídas a um local comum especifico onde serão clivadas e ativadas por determinadas moléculas. Dessa maneira, as pró-caspases-8 e -10 são recrutadas através da resposta dos 
complexos transmembrânicos ativados (FADD/TRADD), e a oligomerização de prócaspase-9 é similarmente mediada por Apaf-1.

b. sugere-se que as caspases, principalmente iniciadoras, também podem sofrer ativação autocatalítica, possuindo um elevado nível de atividade residual sensível a estímulos pró-apoptóticos.

c. finalmente, as caspases efetoras são ativadas principalmente pelo mecanismo de transativação, em que uma protease age sobre a outra. Uma vez ativadas, caspases-8 e -9 são capazes de propagar o sinal apoptótico através da clivagem de caspases efetoras $-3,-6$ ou -7 .

A ativação de caspases não resulta somente na degradação descoordenada de proteínas, mas sim em clivagem seletiva de domínios regulatórios negativos ou indiretamente em inativação de subunidades inibidoras. Em consequência de sua ativação, as caspases apoptóticas promovem a clivagem de muitos constituintes essenciais do citoesqueleto celular, que caracterizam a morfologia da apoptose. Esses substratos incluem componentes de microfilamentos de actina (como miosina, a-actina, filamina, gelsonina), proteínas associadas ao microtúbulos e proteínas do filamento intermediário (vimentinas, queratinas e lamininas nucleares). Dessa maneira, a proteólise desses componentes contribui para a retração e conformação específica da célula em estágios iniciais de apoptose e também para a fragmentação nuclear e formação dos corpos apoptóticos. Além disso, a perda de contato com a matriz extracelular também é tipicamente observada durante a apoptose, facilitando a remoção dos restos celulares pelos fagócitos. Esse processo por sua vez envolve a desestruturação dos locais de adesão focal entre célula-matriz (como cateninas) e complexos de adesão célula-célula (como desmossomos e caderinas) (Hengartner, 2000; Nicholson, 1999; Taylor et al., 2008).

Apesar de representarem moléculas regulatórias fundamentais para a função apoptótica, relata-se que as caspases também estão envolvidas em outros processos de morte celular não-apoptóticos, como necroptose e autofagia, além de participar de mecanismos inflamatórios, diferenciação, proliferação (reparo e morfogênese) e tumorigênese. Estudos em modelos transgênicos animais já demonstraram diversas alterações em desenvolvimento na ausência de 
determinadas caspases, evidenciando a existência de outras funções nãoapoptóticas vitais para tais processos (Miura, 2012; Shalini et al., 2014).

\subsubsection{Família BCL-2}

As diversas proteínas que compõem a chamada família Bcl-2 representam reguladores intracelulares fundamentais na via apoptótica intrínseca. A descoberta dessa família de proteínas ocorreu com a identificação do gene BCL-2 ligado a um loco da cadeia de imunoglobulina, cuja translocação no cromossomo $t(14 ; 18)$ resulta em uma elevada expressão de Bcl-2 e foi associada à maioria dos linfomas de células B ou a leucemias crônicas. O produto deste proto-oncogene é capaz de prorrogar a sobrevida de diversas células hematopoiéticas, incluindo células B e T, sendo expresso na membrana nuclear, no retículo endoplasmático e na membrana mitocondrial. Assim, o termo Bcl-2 refere-se ao linfoma de células $\mathrm{B}$ ou à leucemia crônica (B-cell leukemia/lymphoma-2) e atualmente seu envolvimento com o processo apoptótico e a progressão neoplásica já está bem estabelecido (Tsujimoto et al., 1985; Youle; Strasser, 2008). Descobriu-se a seguir que a expressão de BCL2 não estava correlacionada com proliferação celular, como se presumia naquela época, mas sim com atividade antiapoptótica em resposta a estímulos patológicos e fisiológicos (McDonnell et al., 1989; Hockenbery et al., 1990).

Um grupo de genes com sequência similar à do $B C L-2$ foi identificada há mais de uma década em mamíferos e também codificam proteínas capazes de influenciar a determinação da viabilidade celular. Diversas proteínas dividem similaridade estrutural com Bcl-2, sendo classificadas em três diferentes categorias definidas pela homologia com as regiões que codificam Bcl-2 (BH1 a $\mathrm{BH} 4)$. Essas proteínas também compartilham funções celulares complementares, atuando essencialmente como indutoras ou repressoras de morte celular programada através da regulação da via intrínseca da apoptose. Proteínas antiapoptóticas apresentam quatro domínios homólogos a Bcl-2 (BH1-BH4) e são geralmente integrados à membrana mitocondrial externa, à membrana do retículo endoplasmático ou estarem presentes no citosol. Por outro lado, membros pró-apoptóticos são divididos em proteínas efetoras e proteínas de domínio $\mathrm{BH}$ (BH3-only proteins). A função primordial dessa 
família é controlar a integridade da membrana mitocondrial externa através de sua permeabilidade, em que o equilíbrio entre as proteínas anti e pró-apoptóticas irá definir a ocorrência ou não da morte celular (Danial; Korsmeyer, 2004; Youle; Strasser, 2008; Chipuk et al., 2010).

Dentre os principais reguladores antiapoptóticos podem ser destacados os chamados Bcl-2, Bcl-xL (isoforma longa), Mcl-1 (leucemia 1 de células mieloides) e $\mathrm{Bcl}-\mathrm{w}$, que atuam prevenindo a liberação de citocromo c, de espécies reativas de oxigênio (EROS) e estabilizando o potencial de membrana da mitocôndria através da inibição direta das proteínas pró-apoptóticas. Por outro lado, dentre as proteínas efetoras, Bax (Bcl-2 associated x protein) e Bak (Bcl-2 antagonist killer 1) ativadas se oligomerizam e originam poros proteolipídicos homodiméricos em meio à membrana mitocondrial externa que interferem na sua permeabilidade e permite 0 extravasamento de citocromo c e SMAC/DIABLO, importantes para a ativação da apoptose. Proteínas de domínio BH3, por sua vez, agem em situações distintas de estresse celular e são subdivididas baseando-se em sua capacidade de se ligar e inibir diretamente a proteínas antiapoptóticas, chamadas sensibilizadoras (como Noxa e Bad - Bcl-2 antagonist of cell death), ou de interagir com ambas proteínas antiapoptóticas e efetoras, chamadas ativadoras diretas (como Bid, Bim e Puma respectivamente $\mathrm{Bcl}-2$ interacting domain death agonist, $\mathrm{Bcl}-2$ interacting mediator of cell death e p-53-upregulated modulator of apoptosis) (Danial; Korsmeyer, 2004; Chipuk et al., 2010).

As proteínas da família $\mathrm{Bcl}-2$ atuam em um equilíbrio funcional para regular o destino celular. O nível de interação entre elas depende da presença e do tipo de estímulo de morte recebido, organizando os rearranjos moleculares necessários para promover o início da apoptose. Isso pode ser exemplificado com a interação clássica entre membros antiapoptóticos Bcl-2 e Bcl-xL, inibem a atividade das proteínas pró-apoptóticas Bax e Bak, ao passo que proteínas de domínio BH3 como Bad, Bid e Puma podem desreprimí-las ao bloquearem esses reguladores antagonistas ou mesmo ligarem-se diretamente a Bax e Bak. Independente do mecanismo, a ativação pró-apoptótica tem um objetivo comum de ativar as caspases através da permeabilização da membrana externa mitocondrial que consequentemente promove a liberação de citocromo c e SMAC/DIABLO. A presença de citocromo c no citoplasma permite então a formação do complexo 
apoptossomo ao se ligar a Apaf-1 e pró-caspase-9, que promove a clivagem de caspases efetoras. A liberação de SMAC/DIABLO por sua vez antagoniza a ação das proteínas inibidoras da apoptose (IAPs), porém sugere-se que represente uma via adicional, uma vez que sua deleção não resulta em fenótipo característico em modelos in vivo (Figura 2.4) (Youle; Strasser, 2008; Chipuk et al., 2010).

\subsubsection{Proteínas Inibidoras da Apoptose (IAP)}

A patogênese de diversas doenças está correlacionada à desregulação dos mecanismos que mantem o equilíbrio da morte e sobrevida celular do organismo. Similarmente ao estrito controle molecular para ativar a via apoptótica, uma complexa maquinaria de sobrevida celular também existe para conferir proteção a estímulos indutores de morte, representada por membros da família Bcl-2 a nível mais apical de ativação, e pelos inibidores de apoptose (IAP) a nível mais avançado da cascata apoptótica (Figura 2.4) (Altieri, 2010).

O grupo das IAPs foi caracterizado há mais de duas décadas, e oito diferentes proteínas foram identificadas em humanos até o momento. Tratam-se de proteínas multifuncionais, mas originalmente foram descritas apenas como inibidores fisiológicos das caspases, representando a segunda via de inibição das caspases (Crook et al., 1993; Liston et al., 1996; Salvesen; Duckett, 2002). Reprimir a atividade apoptótica através do bloqueio dos sítios de ativação das caspases -3, -7 e -9 é o principal papel dessas proteínas, sendo composta pelos membros survivina, NAIP, XIAP, Ts-XIAP, ML-IAP, c-IAP-1 e c-IAP-2 (Johnson; Howerth, 2004; Elmore, 2007). Porém, hoje se sabe que somente o XIAP é um real inibidor fisiológico das caspases in vivo, além de estar relacionado a uma forte afinidade com as caspases 3, 7 e 9, impedindo sua atividade apoptótica através do bloqueio dos seus sítios de ativação.

Dentre as IAPs, a survivina é estruturalmente o menor membro dessa família, sendo também conhecida como BIRC5 (baculoviral inhibitor of apoptosis repeatcontaining 5). É abundantemente expressa em tecido embrionário e tumoral em humanos, sendo raramente encontrada em tecidos adultos e diferenciados. A 
principal função de survivina é controlar a apoptose através da inibição de Bax e de caspases efetoras e da via extrínseca por Fas (Altieri, 2010). Estudos em modelos animais transgênicos já demonstraram sua importância para o processo de divisão e apoptose celular. A deleção de survivina resulta em letalidade embrionária, defeitos mitóticos e involução tecidual, ao passo que sua superexpressão condicional em células epiteliais ocasionou a redução dos níveis apoptóticos sob estímulo intrínseco e extrínseco (Grossman et al., 2001; Uren et al., 2000). A survivina não articula a inibição da apoptose somente através do bloqueio direto de caspases como ocorre com XIAP. Alternativamente, sugere-se que a survivina pode promover sua ação citoprotetora através de interações cooperativas com outras IAPs, observada em modelos in vivo, ou pelo sequestro de SMAC/DIABLO mitocondrial, prevenindo sua interação pró-apoptótica com XIAP (Dohi et al., 2004; Ceballos-Cancino et al., 2007). A presença de survivina já foi previamente analisada durante o desenvolvimento de glândulas salivares em camundongos e em culturas de células indiferenciadas de glândulas humanas. Sugere-se que a sua expressão represente um importante papel antiapoptótico contribuindo para a manutençnao de estruturas ductais e permitindo a citodiferenciação acinar (Jaskoll et al., 2001; Szlávik et al., 2008).

Considerando o exposto, muitas evidências na literatura têm sugerido importante atuação do mecanismo apoptótico durante a embriogênese e no controle de desordens associadas, porém muitas questões ainda não foram propriamente investigadas. Para permitir o correto funcionamento das glândulas salivares, a adequada abertura luminal dos ductos epiteliais é imprescindível, assim como compreender os mecanismos que regulam sua formação e manutenção. Muito ainda tem se debatido sobre a verdadeira demanda apoptótica na formação luminal dos ductos salivares, e os dados obtidos contribuem para esclarecer algumas questões pertinentes. A hipoplasia ou disfunção glandular resulta em danos importantes à saúde bucal e qualidade de vida, ainda representando um crítico problema de saúde pública. De maneira a embasar estudos translacionais de fundamento clínico em regeneração tecidual, a profunda investigação realizada nessa tese contribui para um melhor entendimento dos processos morfogenéticos das glândulas salivares, gerando potencial conhecimento para futuras pesquisas. 


\section{OBJETIVOS}

A investigação dos mecanismos de desenvolvimento envolvidos na formação das glândulas salivares consiste em um passo fundamental para contribuir para pesquisas translacionais, particularmente no âmbito de regeneração tecidual. Até o momento evidências na literatura já demonstraram a presença de atividade apoptótica durante a morfogênese das glândulas salivares em modelos animais, porém raramente relatada em humanos. Sugere-se que a apoptose seja essencial no mecanismo de abertura do espaço luminal do sistema de ductos pelo mecanismo de cavitação, em que as células centrais dos cordões epiteliais sólidos entram em processo de morte celular programada. Recentemente, a demanda e a regulação temporal da apoptose tem sido discutida em modelos transgênicos, e sugere-se que a ativação da apoptose é também capaz de induzir funções não-apoptóticas em células circunvizinhas.

O principal objetivo deste projeto é analisar a localização e a expressão temporal de moléculas apoptóticas na abertura luminal dos ductos glandulares em modelo humano e animal. O perfil de expressão de determinadas proteínas anti e pró-apoptóticas da via intrínseca durante a morfogênese das glândulas salivares humanas foi primariamente investigado, visto que se relata maior atividade desta via de sinalização em processos de desenvolvimento. Assim, as proteínas Bax, Bak, Bad, Bid, Bcl-2, Bcl-x, Bcl-xL, caspase-3 clivada, caspases-6, -7 e -9, apaf-1, survivina e citocromo $c$ foram analisadas por imunoistoquímica em correlação com cada estágio de desenvolvimento glandular.

Considerando a expressão de importantes marcadores apoptóticos durante o desenvolvimento glandular humano, realizaram-se experimentos funcionais in vitro de glândulas salivares embrionárias de camundongo para avaliar o efeito da inibição da apoptose através do bloqueio de caspases em culturas de tecido. Para isso, o estágio de maior atividade apoptótica foi inicialmente determinado pela análise da expressão de marcadores específicos de morte celular como Lysotracker, TUNEL e caspase-3 clivada durante o desenvolvimento normal das glândulas salivares. 


\subsection{OBJETIVO GERAL}

- Investigar o perfil de expressão de diversas proteínas anti e pró-apoptóticas durante a morfogênese das glândulas salivares humanas e verificar se o mecanismo apoptótico é essencial para a abertura luminal do sistema de ductos das glândulas salivares.

\subsection{OBJETIVOS ESPECÍFICOS}

- Relacionar a expressão de proteínas anti e pró-apoptóticas do mecanismo intrínseco de acordo com cada estágio morfogenético das glândulas salivares humanas em desenvolvimento;

- Analisar e comparar a expressão temporal e morfológica de marcadores específicos de atividade apoptótica TUNEL e caspase-3 clivada durante as fases iniciais de desenvolvimento das glândulas salivares em camundongo;

- Investigar o efeito da inibição de apoptose in vitro no processo de ramificação e de formação ductal/luminal de cultivos de glândulas salivares embrionárias de camundongo a partir de estágios precoces de desenvolvimento. 


\section{MATERIAIS E MÉTODOS}

\subsection{ESPÉCIMES HUMANOS}

\subsubsection{Obtenção dos Espécimes}

Espécimes de glândulas salivares de fetos humanos provenientes de abortos espontâneos foram obtidos na Faculdade de Medicina da Universidade de São Paulo (USP). Os fetos utilizados no presente estudo variavam entre 9 e 25 semanas de vida intrauterina (VIU) de acordo com a relação da medida plantar (McBride et al., 1984). Tal metodologia tem sido utilizada e reconhecida por mais de 90 anos para predizer a idade gestacional de fetos humanos tanto em tecidos frescos como fixados (Streeter, 1920; Mandarim-de-Lacerda, 1990). Todos os fetos constituíam peças cirúrgicas por pesarem menos de 500 gramas e seu emprego neste trabalho foi aprovado pelo Comitê de Ética da Faculdade de Odontologia da mesma instituição.

Foram utilizados um total de 70 espécimes durante a evolução da pesquisa deste projeto. Dentre eles, os melhores espécimes foram selecionados para a realização das reações de imunoistoquímica ( $\mathrm{N}=15$ para cada proteína), incluindo todas as fases da morfogênese glandular pertinentes para análise. Todos os espécimes foram fixados em formalina tamponada a 10\%, e as regiões de interesse foram dissecadas e lavadas em água destilada (Figura 4.1). A seguir, os espécimes foram desidratados com banhos de etanol, $1 \mathrm{~h}$ em solução de xilol e posteriormente 1h em parafina líquida. Realiza-se uma última troca de parafina líquida para a inclusão final do tecido. Os espécimes emblocados em parafinas seguem para a microtomia, em que cortes seriados de $4 \mu \mathrm{m}$ são montados individualmente para o processamento de coloração e imunoistoquímica. 

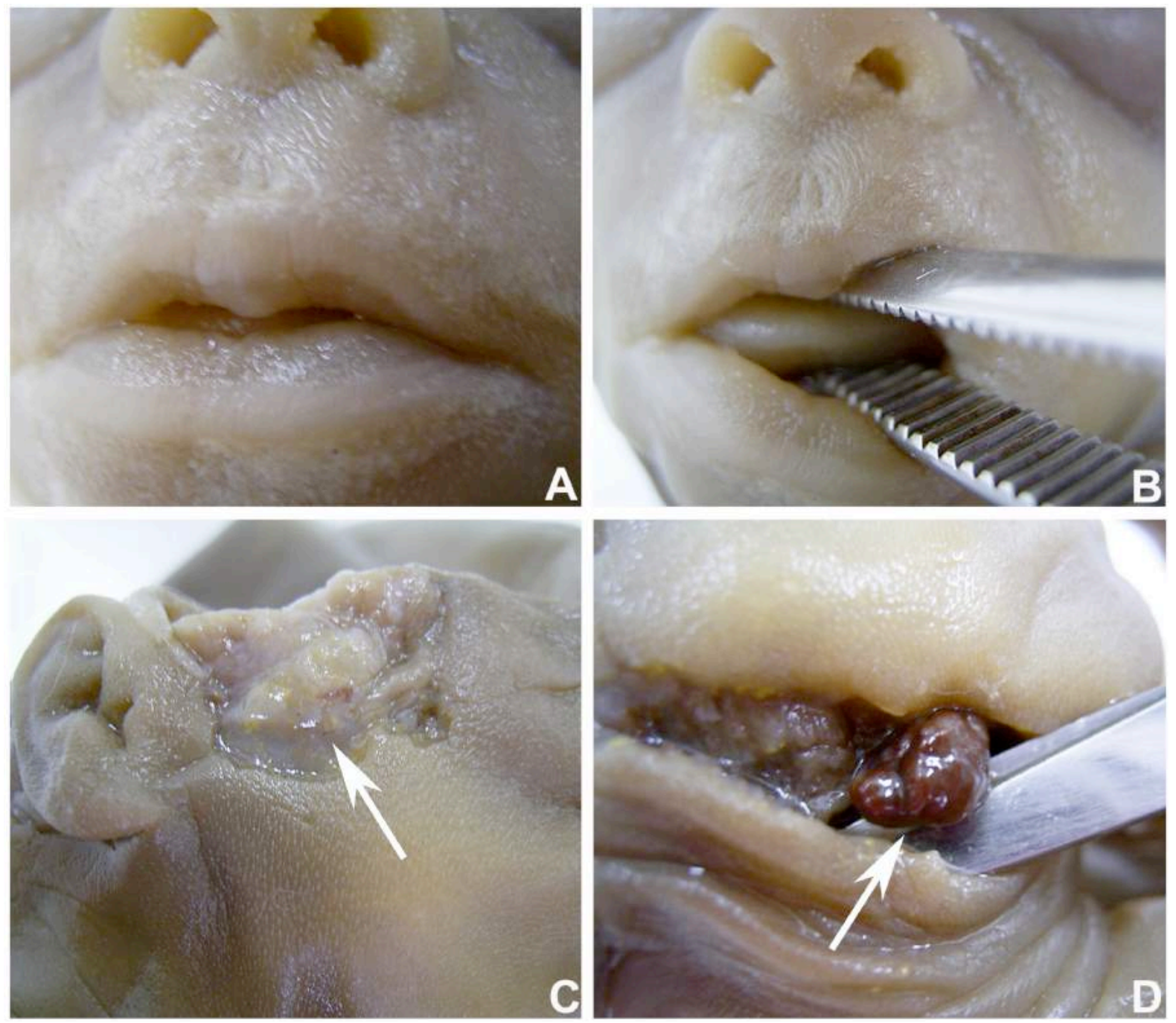

Figura 4.1 - Dissecção das glândulas salivares de fetos humanos. (A) lábios superior e inferior, (B) língua, (C) glândula parótida (seta), (D) glândula submandibular (seta) 


\subsubsection{Imunoistoquímica}

Cortes parafinados de $4 \mu \mathrm{m}$ de espécimes selecionados - parótida, submandibular e glândulas salivares menores do palato e assoalho foram inicialmente desparafinizados em dois banhos de xilol: o primeiro a $60^{\circ} \mathrm{C}$ por 30 minutos e o segundo à temperatura ambiente (TA) por 20 minutos. A seguir os cortes foram reidratados em cadeia decrescente de etanol (100\%, 95\% respectivamente) e imersos em solução de hidróxido de amônia a 10\% durante 10 minutos para a remoção de pigmentos formólicos. A recuperação dos epítopos antigênicos foi realizada de acordo com o soro primário utilizado, respectivamente detalhada na Tabela 4.1.

Após a lavagem em água corrente e água destilada, foi realizada a incubação do material em solução de peróxido de hidrogênio 20 volumes por 10 minutos com o intuito de bloquear a peroxidase endógena tecidual. Repetida a lavagem com água corrente e água destilada, os cortes foram imersos duas vezes em solução de solução tampão salina (PBS, pH 7,4) por dois minutos cada lavagem. Em seguida, os cortes foram incubados com soro primário diluído em solução de $1 \%$ BSA (Sigma®) em PBS por 60 minutos. As informações acerca da diluição e da procedência dos anticorpos primários também estão descritas na Tabela 4.1. Os procedimentos seguintes foram todos precedidos de duas lavagens em tampão PBS.

Após a incubação com o anticorpo primário, os espécimes foram incubados com anticorpo secundário Polímero Novolink (Dako Cytomation®) em 2 etapas de 30 minutos cada. A revelação dos marcadores foi desenvolvida pela incubação dos espécimes no revelador permanente diaminobenzidina (DAB, Dako Cytomation®) por 3 minutos, que evidencia a reação por meio de coloração acastanhada. Os cortes foram então lavados em tampão PBS, água corrente e água destilada e contra-corados com hematoxilina de Carazzi por 5 minutos. Finalmente, os espécimes foram montados em resina permount para o exame ao microscópio de luz.

Os controles negativos das reações supracitadas foram realizados por meio da incubação dos espécimes com soro não-imune, e os positivos foram analisados 
de acordo com as especificações do fabricante de cada anticorpo. Todas as reações foram realizadas em triplicata, e os resultados foram analisados em microscópio óptico de luz e registrados com equipamento fotográfico digital (Olympus BX41).

Tabela 4.1 - Dados dos anticorpos primários utilizados no estudo em glândulas salivares humanas com respectivos clones, títulos, procedências e modo de recuperação antigênica

\begin{tabular}{|c|c|c|c|c|}
\hline Soro primário & Clones & Título & Procedência & $\begin{array}{c}\text { Recuperação } \\
\text { antigênica }\end{array}$ \\
\hline Bax & policlonal & $1: 400$ & Dako & Citrato, $\mathrm{pH} 6.0$ \\
\hline Bak & policlonal & $1: 300$ & Dako & Citrato, $\mathrm{pH} 6.0$ \\
\hline Bad & Y208 & $1: 500$ & Epitomics & EDTA, pH 9.0 \\
\hline Bid & $\mathrm{BH} 3$ & $1: 100$ & Epitomics & Citrato, $\mathrm{pH} 6.0$ \\
\hline $\mathrm{Bcl} 2$ & 124 & $1: 200$ & Dako & Citrato, $\mathrm{pH} 6.0$ \\
\hline Bcl-x & Polyclonal & $1: 500$ & Dako & Citrato, $\mathrm{pH} 6.0$ \\
\hline Bcl-xL & 7D9 & $1: 2000$ & Chemicon & Citrato, $\mathrm{pH} 6.0$ \\
\hline Caspase 3 clivada & policlonal & $1: 600$ & $\begin{array}{c}\text { Cell } \\
\text { Signaling }\end{array}$ & Citrato, $\mathrm{pH} 6.0$ \\
\hline Caspase 6 (c-term) & E180 & $1: 150$ & Epitomics & EDTA, pH 9.0 \\
\hline Caspase 7 & 7CSP01 & $1: 150$ & Chemicon & Citrato, $\mathrm{pH} 6.0$ \\
\hline Caspase 9p10 & 1183 & $1: 500$ & Santa Cruz & Citrato, $\mathrm{pH} 6.0$ \\
\hline Apaf 1 & policlonal & $1: 30$ & Novocastra & Citrato, $\mathrm{pH} 6.0$ \\
\hline Citocromo c & СTC05 & $1: 3000$ & Chemicon & Citrato, $\mathrm{pH} 6.0$ \\
\hline Survivina & policlonal & $1: 400$ & Neomarkers & EDTA, pH 9.0 \\
\hline
\end{tabular}




\subsection{ESPÉCIMES ANIMAIS}

\subsubsection{Obtenção dos Espécimes}

Os experimentos em animais foram desenvolvidos em colaboração com o Departamento de Desenvolvimento Craniofacial e Biologia de Células-Tronco do King's College London (Londres, Reino Unido), realizados de acordo com a aprovação do comitê de ética local. Os camundongos albinos da linhagem CD1 foram mantidos na Unidade de Serviços Biológicos (BSU) da Instituição, sendo assistidos e gerenciados pela equipe técnica.

Durante estágios precoces do desenvolvimento embrionário E12.5 a E14.5, as glândulas salivares de camundongos foram dissecadas da região submandibular de maneira a se obter ambas as glândulas submandibular e sublingual simultaneamente na mesma cápsula mesenquimal, considerando sua favorável anatomia (modelo de dissecção em estágio intermediário E13.5 na Figura 4.2). Durante todo o processo de dissecção foi utilizado o meio de cultura Advanced Dulbecco's Modified Eagle Medium F12 (DMEM F12) (Invitrogen®) suplementado com 1\% Glutamax ${ }^{T m}$ (Invitrogen®) e 1\% de penicilina-estreptomicina. Trata-se de um meio nutritivo que permite o cultivo de glândulas salivares sem a necessidade de suplementação sorológica, como descrito por previamente (Hoffman et al., 2002). 


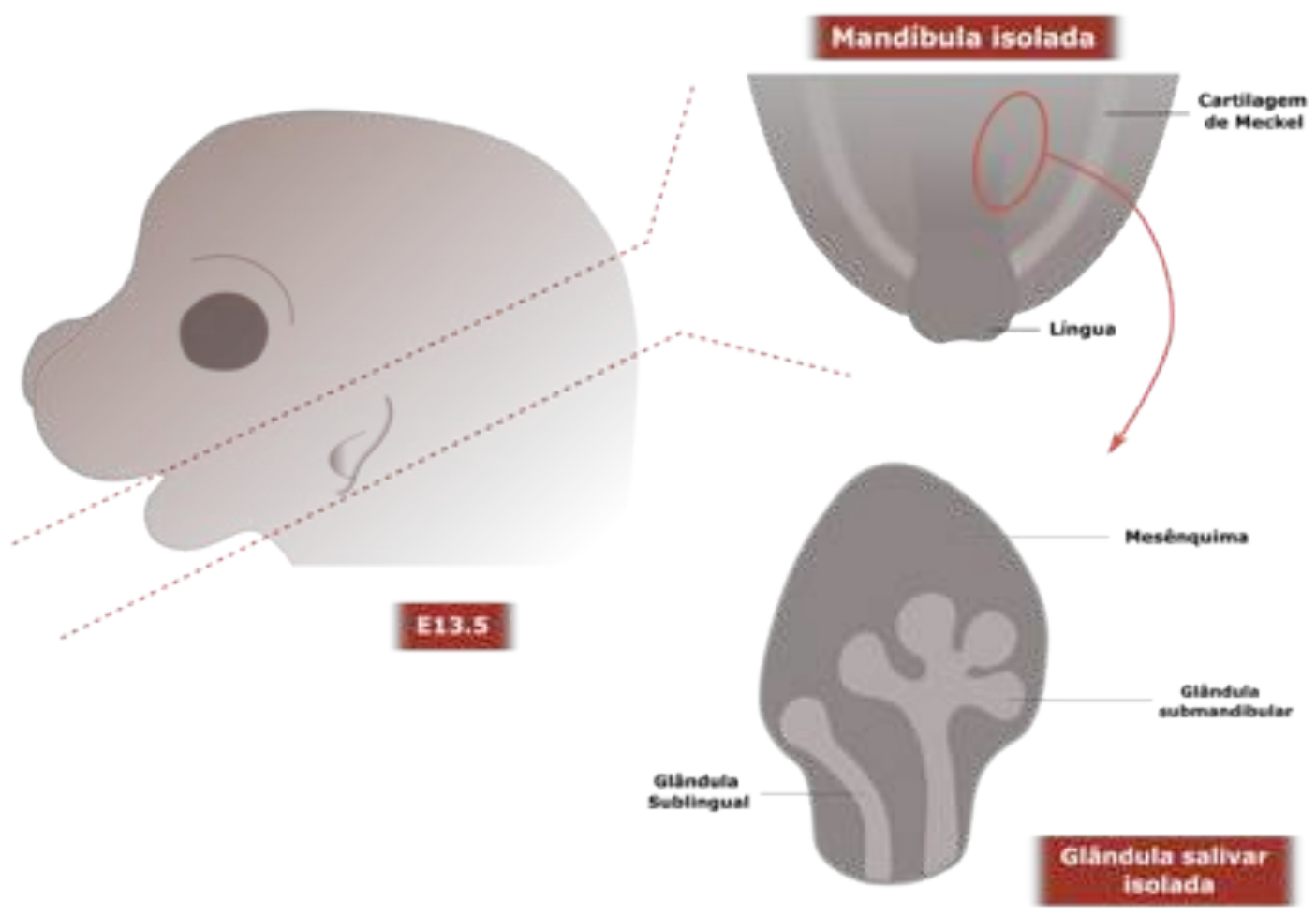

Figura 4.2 - Esquema representativo do procedimento de dissecção das glândulas salivares submandibular e sublingual de camundongo CD1

Modelo de dissecção de glândulas salivares submandibular e sublingual em estágio E13.5. Nessa fase, as estruturas epiteliais rudimentares envolvidas por uma densa cápsula mesenquimal que permite facilmente sua remoção da região entre a base da língua e a cartilagem de Meckel.

\subsubsection{Processamento dos Espécimes}

A fixação de glândulas salivares isoladas foi realizada pela incubação das amostras em paraformaldeído a 4\% (PFA, Alfa Aesar®) em PBS por 30 min à temperatura ambiente (TA). Após a remoção do PFA com lavagens em PBS, seguese com o processo de desidratação dos tecidos fixados através de soluções de metanol em concentrações crescentes (Tabela 4.2). O tempo de incubação da fixação e desidratação dos espécimes depende diretamente do seu estágio de desenvolvimento (Tabela 4.3).

Espécimes desidratados pelo metanol seguem com a incubação em isopropanolol (100\%) (Acros Organic $®$ ), realizando-se uma lavagem à TA (com duração equivalente às lavagens de metanol) e uma a $4^{\circ} \mathrm{C}$ overnight. Posteriormente, soluções de 1,2,3,4-tetrahidronaftaleno (THN) promovem a 
diafinização dos espécimes, preparando-os para a inclusão em parafina histológica (Ultraplast, Solmedia ${ }^{\circledR}$ ) a $65^{\circ} \mathrm{C}$, trocados a cada uma hora até a total remoção de vestígios de THN (6 lavagens até remoção completa). Desidratações realizadas com etanol devem ser seguidas com duas lavagens em Histoclear $I^{T M}$ (National Diagnostics $($ ) ) à TA, mantendo-se o mesmo tempo de lavagem de acordo com a Tabela 4.2, prosseguindo diretamente à inclusão em parafina. Para a confecção dos blocos parafinados, os espécimes foram adequadamente posicionados em fôrmas metálicas a $65^{\circ} \mathrm{C}$ ainda em parafina plastificada, que foi solidificada a $4^{\circ} \mathrm{C}$ overnight.

Os blocos de parafina contendo os espécimes de estudo foram seccionados com o uso de um micrótomo (RM2245, Leica $($ ) em cortes de $7 \mu \mathrm{m}$, sendo montados em lâminas silanizadas (Superfrost Plus ${ }^{\mathrm{TM}}$, VWR International $($ ) para experimentos subsequentes. Os cortes foram montados em banho-maria a $42^{\circ} \mathrm{C}$ (Electrothermal ${ }^{\circledR}$ ) e deixados sobre uma superfície aquecida (Thermo Scientific $®$ ) overnight à mesma temperatura de montagem, promovendo a secagem e a adesão das secções parafinadas sobre as lâminas de vidro.

Tabela 4.2 - Tempo de incubação mínimo dos espécimes animais de acordo com o estágio de desenvolvimento. Os valores referem-se ao espécime de interesse e todos à temperatura ambiente ( $\mathrm{E}=$ embrionário)

Estágio de desenvolvimento

E11.5 a E13.5, glândulas isoladas

Cabeça E14.5

Cabeça E15.5

Cabeça E16.5
Tempo de incubação

$30 \mathrm{~min}$

$50 \mathrm{~min}$

$90 \mathrm{~min}$

$120 \mathrm{~min}$ 
Tabela 4.3 - Etapa de desidratação do processamento dos espécimes animais Sequência de desidratação em concentrações crescentes de metanol realizada em tecidos previamente fixados com respectivas temperaturas de armazenamento

Solução

$30 \%$ metanol, $70 \%$ PBS

$50 \%$ metanol, $50 \%$ PBS

$70 \%$ metanol, $30 \%$ PBS

$80 \%$ metanol, $20 \% \mathrm{dH}_{2} \mathrm{O}$

$90 \%$ metanol, $10 \% \mathrm{dH}_{2} \mathrm{O}$

$95 \%$ metanol, $5 \% \mathrm{dH}_{2} \mathrm{O}$

$100 \%$ metanol
Armazenamento

\subsubsection{Histologia}

A visualização da morfologia glandular e sua relação aos tecidos adjacentes em diferentes estágios de desenvolvimento foi possível através de coloração histoquímica de hematoxilina e eosina (HE). Para isso, inicialmente removeu-se a parafina com lavagens em Histoclear ${ }^{\mathrm{TM}}$, seguidas pela reidratação dos tecidos através da incubação em solução decrescente de etanol (100, 90, 70, 50 e 30\%) em PBS. Após a lavagem com água deionizada por dois minutos, os espécimes foram incubados em hematoxilina de Ehrlich (Solmedia ${ }^{\circledR}$ ) por dez minutos, removendo-se o excesso em água corrente por mais dez minutos. Subsequentemente, as secções foram imersas em solução de $1 \%$ de ácido clorídrico em etanol por 15 segundos, lavadas em água corrente por mais dez minutos e então coradas com eosina aquosa a $0.5 \%$ (Sigma-Aldrich $®)$ por cinco minutos. Após duas lavagens com água deionizada, fez-se a desidratação dos espécimes (com duas lavagens em etanol $100 \%$ ) seguida de incubação em Histoclear ${ }^{\mathrm{TM}}$ e finalmente finalizados com meio de montagem Neo-Mount (Merck®). 


\subsubsection{Imunofluorescência}

A expressão de proteínas envolvidas no mecanismo apoptótico pôde ser detectada através de reações imunoistoquímicas, realizadas em secções de tecidos parafinados e em espécimes inteiros (técnica whole mount), devido ao tamanho reduzido das amostras obtidas. Para avaliar a formação luminal das glândulas salivares, reações para diferentes marcadores de elementos ductais ou de essencial atividade apoptótica foram realizadas no intuito de se analisar temporal e morfologicamente sua participação e expressão.

Cortes de tecidos parafinados de $7 \mu \mathrm{m}$ foram submetidos à reidratação através do uso de Histoclear ${ }^{\mathrm{TM}}$ (duas lavagens de 10 minutos cada) seguido de imersão dos espécimes em soluções de concentração descendente de etanol por dois minutos cada. Uma vez reidratados, realizou-se o bloqueio de peroxidase endógena com $3 \%$ de $\mathrm{H}_{2} \mathrm{O}_{2}$ em PBS por 15 minutos, sendo posteriormente submetidos à recuperação antigênica em solução de citrato a uma concentração de $10 \mathrm{mM}(\mathrm{pH} 6,0)$ e $0.5 \%$ de Tween-20. A solução foi previamente aquecida por cinco minutos em micro-ondas de média a alta potência, em que os espécimes foram então aquecidos por mais sete minutos. Após o resfriamento natural da solução à temperatura ambiente, promoveram-se três lavagens de dois minutos em PBS dos espécimes, que depois foram incubados em solução bloqueadora (10\% de soro fetal bovino em 1\% Triton em PBS) por uma hora à temperatura ambiente. Após essa etapa, as amostras foram deixadas overnight a $4^{\circ} \mathrm{C}$ com o anticorpo primário (1:200 Caspase-3 clivada, Cell Signalling $\AA$; 1:100 Queratina 7, Abcam $®)$, que foi removido no dia seguinte com PBS para a incubação seguinte com o anticorpo secundário (1:300, Alexa Fluor, Invitrogen®). Por fim, realizou-se a última lavagem dos espécimes com PBS e a montagem das lâminas com Fluoroshield (ab104139, Abcam®).

Para a realização da imunoistoquímica através de técnica TUNEL (Terminal Deoxynucleotidyl Transferase dUTP Nick End Labeling), os espécimes foram reidratados da mesma maneira como citado anteriormente e seguiu-se com o protocolo do fabricante (ApopTag Peroxidase In Situ Apoptosis Detection Kit, S7100, 
Millipore () ), em que se adaptou a concentração da enzima TdT (15\%) e o modo de revelação (diluição de 1:100 por 10 minutos, TSA fluoresceína NEL701A001,Perkin Elmer®). A montagem das lâminas foi realizada com o meio Fluoroshield e posteriormente visualizadas por microscopia confocal a laser (TCS SP4, Leica).

Para a técnica de imunofluorescência whole mount, os espécimes frescos foram inicialmente fixados com solução de formaldeído à TA por tempo determinado pelo seu volume de acordo com o estágio de desenvolvimento (Tabela 2). Após a remoção do fixador com lavagens em PBS, o tecido foi permeabilizado com 0,1\% Triton em PBS (PBSTr) à TA e deixados em solução bloqueadora por $2 \mathrm{~h}$ a $4^{\circ} \mathrm{C}(10 \%$ soro fetal bovino e $1 \%$ BSA em PBSTr) para o bloqueio de proteínas inespecíficas. $\mathrm{O}$ anticorpo primário foi adicionado à solução bloqueadora por 3 noites a $4^{\circ} \mathrm{C}(1: 200$ Caspase-3 clivada, Cell Signalling ${ }^{\circledR}$ ). O excesso foi removido com lavagens em PBS seguidas pela incubação do anticorpo secundário (1:500 Alexa Fluor, Invitrogen®) e em DAPI (1:1000, Invitrogen $®)$ na mesma solução bloqueadora por 2 noites a $4^{\circ} \mathrm{C}$. Removeu-se os anticorpos com seis lavagens de 20 minutos em PBSTr, duas de PBS e finalmente montados em lâminas com meio de montagem Fluoroshield (Abcam $\left.{ }^{\circledR}\right)$. Os resultados foram obtidos e registrados através da visualização dos espécimes no microscópio confocal de escaneamento a laser (TCS SP5, Leica®).

\subsubsection{Cultura de Tecido}

Os espécimes obtidos através da dissecção foram submetidos à cultura sobre membranas permeáveis (Falcon Cell Culture inserts, BD Biosciences $₫$ )(poros de $0,4 \mu \mathrm{m}$ ) sobrenadantes ao meio DMEM F12 e incubados a $37^{\circ} \mathrm{C}$ e $5 \% \mathrm{CO}_{2}$.

Para os testes funcionais, o pan-inibidor Z-VAD-FMK (G7231, Promega ${ }^{\circledR}$ ) foi utilizado para promover a inibição de caspases in vitro em culturas de glândulas salivares embrionárias, tornando possível analisar os efeitos do bloqueio do mecanismo apoptótico para o desenvolvimento glandular. Glândulas salivares submandibular e sublingual dissecadas de um mesmo embrião foram pareadas, utilizando-se uma como grupo controle e a outra como experimental, inibindo-se a atividade das caspases com a adição do inibidor em concentrações graduais de 


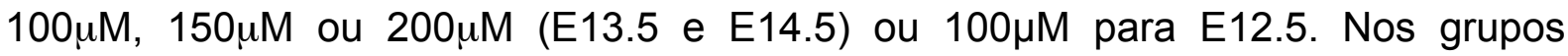
controle, adicionou-se ao meio de cultura a mesma concentração do veículo utilizado no inibidor, o dimetilsulfóxido (DMSO), que limita o seu uso a uma concentração máxima de $1 \%$ devido ao seu potencial citotóxico. Os espécimes glandulares foram cultivados por um período de até $72 \mathrm{~h}$. Para os experimentos com marcação do inibidor com FITC, CaspACE FITC-Z-VAD-FMK (G7461, Promega ${ }^{\circledR}$ ) foi adicionado ao meio de cultura no último dia por $3 \mathrm{~h}$. Após o período de cultivo, as glândulas eram fixadas por 30 min à TA, seguindo-se ou não com imunoistoquímica. Registros fotográficos eram realizados aproximadamente a cada $24 \mathrm{~h}$.

\subsubsection{Lysotracker}

Realizada em tecidos vivos, a reação com Lysotracker RED foi obtida através da incubação das SG com o meio de cultura HBSS ou DMEM F12 diluído em 5mM de Lysotracker RED (DND99, Invitrogen®) a $37^{\circ} \mathrm{C}$ por 30 minutos. Posteriormente, lavagens dos espécimes de 20 minutos cada foram realizadas com o mesmo meio de cultura, 0,1\% Tween-20 em PBS (PBT) e PBS à temperatura ambiente. Os tecidos foram fixados em $4 \%$ de PFA por 2 horas ou overnight a $4{ }^{\circ} \mathrm{C}$, lavados com PBS.

\subsubsection{Análise Morfométrica de Culturas das Glândulas salivares}

A determinação da influência do inibidor de caspases na ramificação das culturas de glândula salivar de camundongos foi obtida através da análise de Spooner ratio (Spooner; Bassett, 1989), em que se divide o número de ramificações presentes em determinado período pela quantidade existente no início da cultura. Similarmente, mediu-se a largura máxima dos ductos excretores das glândulas submandibulares obtida nas culturas com o inibidor de apoptose (Z-VAD-FMK) de todas as concentrações para verificar o efeito direto morfogenético da ausência de 
caspases nos ductos glandulares. Dessa maneira, a contagem dos botões epiteliais e a medida da largura dos ductos foram realizadas manualmente através do uso de fotografias das culturas no sistema de imagens ImageJ. Os dados obtidos foram transferidos e analisados para o Microsoft Office Excel 2011, e a construção dos gráficos e análises estatísticas foram realizadas no Graphpad Prism 5, tomando-se o nível estatístico significativo como $p<0.05$. 


\section{RESULTADOS}

\subsection{ANÁLISE MORFOLÓGICA DOS ESTÁGIOS DE DESENVOLVIMENTO GLANDULAR}

A classificação dos estágios de desenvolvimento das glândulas salivares foi descrita previamente em análises realizadas em modelo animal que se basearam na formação de estruturas características e pertinentes à estrutura glandular (Jaskoll; Melnick, 1999). A similaridade de tal padrão de desenvolvimento já foi atribuída a glândulas salivares humanas, sendo atualmente aceito e utilizado para classificar e analisar os estágios morfogenéticos do tecido glandular humano (Figura 5.1) (Lourenço; Kapas, 2005; Lourenço et al., 2008; Teshima et al., 2011). De maneira geral, o início do processo ocorre com o espessamento do epitélio oral primitivo por volta do estágio embrionário $E 11$, caracterizando a fase de pré-botão. A intensa e contínua proliferação dessas células invaginam em direção ao mesênquima subjacente e originam o primeiro botão epitelial conectado ao epitélio oral por um cordão sólido que caracteriza a fase de botão inicial em E12.5 (Figuras 5.1A, 5.1F, $5.1 \mathrm{~K}$, setas). A seguir, múltiplos botões epiteliais se originam com a ramificação do botão epitelial primário inserido em um mesênquima mais condensado, correspondendo à fase pseudoglandular a partir de E13.5 (Figuras 5.1B, 5.1G, 5.1L), já exibindo a presença do espaço luminal inicial (Figuras 5.1B, 5.1I, setas). Os cordões epiteliais continuam a proliferar e passam pelo processo de canalização com a expansão dos espaços luminais na chamada fase canalicular no estágio E14.5 (Figuras 5.1C, 5.1H, 5.1M, setas). Por fim, a diferenciação dos ductos glandulares e botões epiteliais em ácinos funcionais caracterizam o estágio final de amadurecimento da glândula salivar denominado fase de botão terminal que ocorre a partir de E15.5 até a fase pós-natal (Figuras 5.1D, 5.1E, 5.1I, 5.1J, 5.1N, 5.1O, setas). 


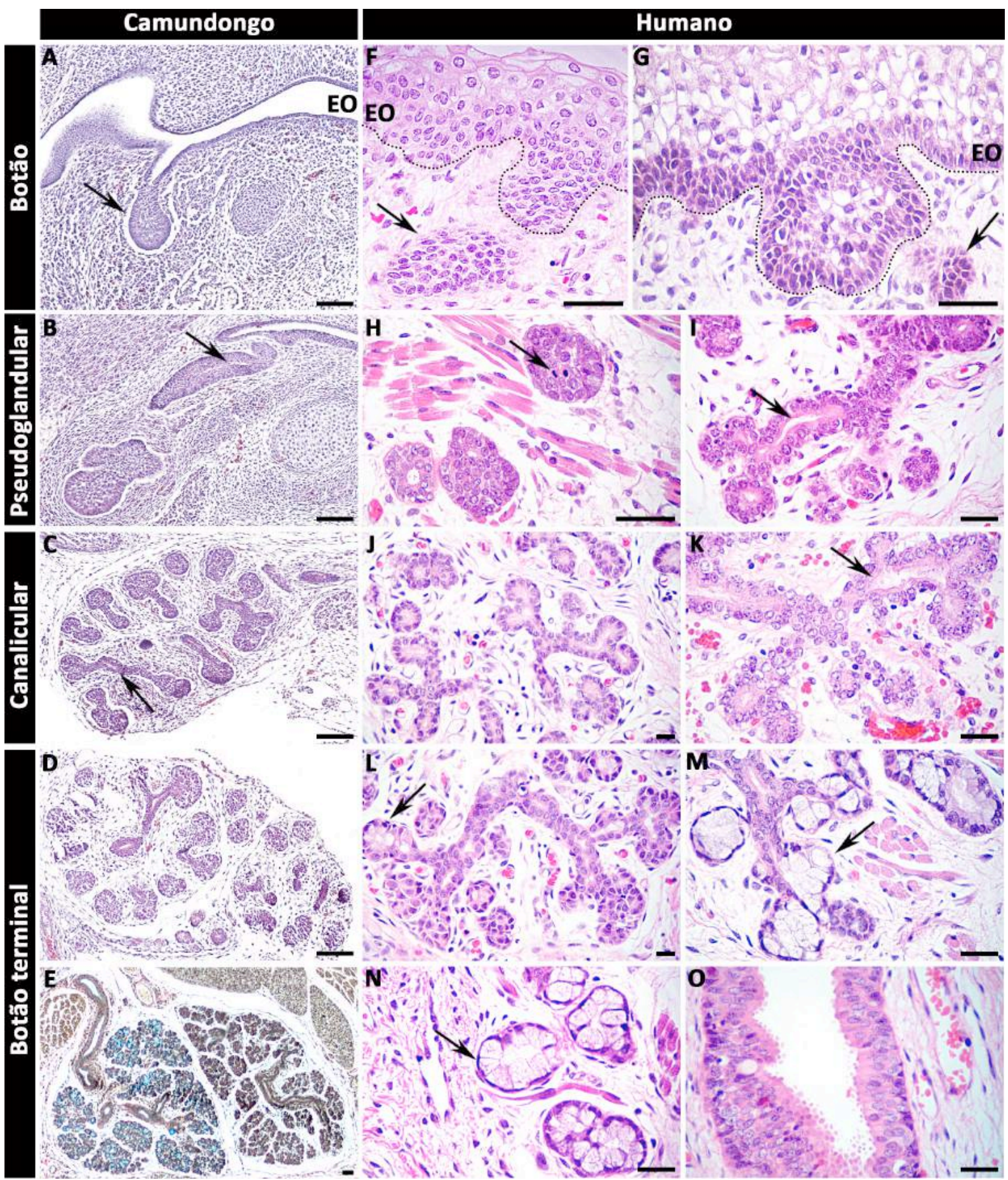

Figura 5.1 - Imagens comparativas dos estágios morfogenéticos das glândulas salivares maiores humanas e de camundongo. (A-E) Glândulas salivares de camundongo. (F-O) Glândulas salivares humanas. (A, F, G) Fase de botão exibindo a proliferação inicial de células do epitélio oral primitivo (EO) em direção ao mesênquima subjacente que origina os primeiros botões epiteliais (setas). (B, H, I) Fase pseudoglandular com cordões epiteliais ramificados e início da formação de lúmen central (B, I, setas); célula em ativa proliferação em broto epitelial (H, seta). (C, J, K) Fase canalicular com cordões epiteliais mais ramificados e exibindo múltiplos ductos com espaço luminal bem definido (C, K, setas). (D, E, L, M, N, O) Fase de botão terminal com a presença de ductos extensos e unidades terminais morfologicamente diferenciadas $(E, N$, seta) com células de citoplasma amplo e claro e aspecto piramidal (L, $M, N$, setas). Detalhe da presença de ducto excretor canalizado e de múltipla estratificação epitelial na fase terminal $(\mathrm{O})$. Colorações histológicas por hematoxilina/eosina (A-D, F-O) e tricrômico de Masson (E). Escalas $=100 \mu \mathrm{m}$. 
Em um acervo de mais de 70 fetos humanos coletados pelo nosso grupo de pesquisa, a análise morfológica das glândulas salivares identificou a presença de aspectos característicos à formação glandular de acordo com a evolução dos estágios de desenvolvimento. As glândulas salivares maiores submandibular e parótida são as primeiras estruturas glandulares observadas, embora só finalizem o processo de diferenciação final bem mais tardiamente em relação às glândulas menores devido ao seu maior volume e às suas estruturas mais desenvolvidas. Além disso é importante notar que todas as fases morfogenéticas glandulares podem ser encontradas na mesma idade gestacional em glândulas salivares humanas, representando um padrão proliferativo gradual e progressivo. Portanto, considerou-se a idade gestacional dos fetos humanos secundária à classificação do desenvolvimento glandular, e portanto todos os resultados analisados foram interpretados de acordo com a estruturas teciduais encontradas.

A idade gestacional dos fetos obtidos variou de 4 a 25 semanas, e a análise da formação das estruturas glandulares é descrita a seguir:

4 semanas de vida intrauterina: nessa fase do desenvolvimento fetal identificou-se a presença de cavidade oral primitiva revestida por epitélio simples, ainda não exibindo a formação de rudimentos glandulares menores. Em contrapartida, glândulas maiores parótida e submandibular já apresenta estruturas epiteliais nas fases primárias de desenvolvimento com múltiplos botões e alguns cordões epiteliais sólidos ou com espaço luminal já em formação.

12 semanas de vida intrauterina: brotos de glândulas salivares menores foram encontrados em lábio superior, palato posterior, mandíbula e assoalho bucal. Esses brotos epiteliais sólidos eram majoritariamente compostos por células cuboidais irregulares indiferenciadas e de aspecto basaloide. Na língua e no lábio inferior não foi observada a formação de glândulas salivares menores por todo o espécime. Estruturas ductais mais alongadas em associação com botões epiteliais indiferenciados foram identificados nas glândulas salivares maiores submandibular e parótida, com extensos espaços luminais já presentes apenas com revestimento estratificado simples.

14 semanas de vida intrauterina: nesse estágio as glândulas salivares menores foram observadas no lábio inferior, mucosa jugal, porção anterior da língua 
e palato posterior, exibindo alguns cordões epiteliais ramificados correspondentes à fase pseudoglandular. No soalho bucal e mandíbula as glândulas salivares menores foram observadas no estágio de canalização, tendo em vista o aparecimento de ductos, túbulos e sacos terminais. As glândulas parótida e submandibular apresentavam estruturas epiteliais nos estágios de broto, ramificação epitelial e algumas estruturas em fase de canalização. As células epiteliais exibiam núcleo amplo, citoplasma eosinofílico e, por vezes as estruturas epiteliais mostravam-se contornadas por células fusiformes ou estrelárias. A presença de lóbulos glandulares já se fazia evidente e esses eram separados entre si por um contorno de tecido conjuntivo frouxo bem vascularizado.

16-18 semanas de vida intrauterina: glândulas menores encontradas na porção posterior da língua, palato posterior, mandíbula e assoalho já apresentavam estruturas características do estágio de botão terminal. Portanto, é possível afirmar que durante essa idade gestacional caracteriza-se o início da diferenciação morfológica dos ácinos de glândulas salivares menores, correspondendo os primeiros eventos da fase de botão terminal. As porções terminais das glândulas menores apresentam células acinares morfologicamente diferenciadas com aspecto piramidal, citoplasma amplo, claro, rico em grânulos de secreção e núcleo achatado situado no polo basal da célula. Nesta fase, os túbulos terminais eram compostos por duas camadas celulares, e ao redor das células acinares puderam ser notadas células de aspecto fusiforme, com núcleo achatado e central, interpretadas como prováveis células mioepiteliais. Nas glândulas parótida e submandibular, as estruturas glandulares ainda apresentavam nuances entre os estágios pseudoglandular e canalicular inicial, com a evidência de estruturas que exibiam sacos terminais rudimentares.

19-21 semanas de vida intrauterina: nessa idade gestacional, as porções mais desenvolvidas das glândulas salivares menores dos lábios, da mucosa jugal e língua foram observadas no estágio canalicular. Nas glândulas parótida e submandibular, a maioria das estruturas ainda se encontravam majoritariamente nos estágios pseudoglandular e canalicular, entretanto já era possível identificar lóbulos glandulares bem formados com evidente separação for septo fibrovascular e estruturas epiteliais contornadas por células fusiformes. Algumas estruturas ductais 
já canalizadas encontravam-se mais maduras exibindo epitélio glandular pluriestratificado.

22-25 semanas de vida intrauterina: as glândulas salivares obtidas nesse período exibiam majoritariamente estágio de botão terminal com porções terminais bem diferenciadas exibindo células de citoplasma amplo e claro, por vezes com presença de grânulos. Muitas estruturas ductais nessa fase já exibiam pluriestratificação e os lóbulos de glândulas salivares encontravam-se bem delimitados por septos fibrovasculares. Nas glândulas parótida e submandibular a diferenciação também já se encontra mais avançada com maior número de estruturas nas fases terminais de desenvolvimento e com lóbulos glandulares bem formados.

\subsection{ANÁLISE SEMI-QUALITATIVA DA EXPRESSÃO DE PROTEÍNAS APOPTÓTICAS DURANTE O DESENVOLVIMENTO DAS GLÂNDULAS SALIVARES HUMANAS}

Para verificar a atividade apoptótica intrínseca durante o desenvolvimento das glândulas salivares humanas, investigou-se a expressão de proteínas fundamentais para o processo como membros anti e pró-apoptóticos da família $\mathrm{Bcl}-2$, caspases iniciadoras (caspase-9) e efetoras (caspase-3 clivada, caspase-6 e -7), componentes do complexo apoptossomo (Apaf-1 e Citocromo $C$ ) e o inibidor apoptótico survivina. Todos os resultados foram atribuídos a análises semi-qualitativas reunidas nas Tabelas 5.1, 5.2 e 5.3, que ilustram a localização intracelular de cada proteína de acordo com cada estágio de desenvolvimento glandular humano.

\subsubsection{Resultados Imunoistoquímicos - Família BCL-2}

Representando membros da família $\mathrm{Bcl}-2$, esse estudo incluiu as proteínas pró-apoptóticas Bax, Bak, Bad e Bid, e as antiapoptóticas Bcl-2, Bcl-x e Bcl-xL, cujos 
resultados da análise semi-qualitativa encontram-se discriminados na Tabela 5.1 , e os resultados correspondentes a cada estágio morfogenético são ilustradas na Figura 5.2. A expressão da proteína Bcl-2 foi completamente negativa em todos os espécimes analisados, enquanto Bad e Bid foram observadas somente em um caso isolado $(\mathrm{N}=1 / 15)$. Todas as outras proteínas analisadas $\mathrm{Bax}$, Bad, Bcl-x e $\mathrm{Bcl}-\mathrm{xL}$ foram expressas durante todo o desenvolvimento glandular (Figura 5.2). Embora a presença de Bax tenha sido majoritariamente citoplasmática nas estruturas ductais em desenvolvimento (Figuras 5.2A-E), determinadas células da área central evidentemente expressaram Bax no compartimento nuclear nos prováveis espaços luminais (Figuras 5.2B, 5.2C, setas). Em contraste, a proteína homóloga Bak revelou importante positividade nuclear no interior dos cordões epiteliais até a fase canalicular (Figuras $5.2 \mathrm{~F}-5.2 \mathrm{H}$, setas), ao passo que sua expressão foi exclusivamente citoplasmática na fase de botão terminal (Figura 5.2I, seta). A dupla localização intracelular de ambas proteínas Bax e Bak é ilustrada em detalhe nas Figuras 5.2E e 5.2J, em que células epiteliais do cordão glandular exibem expressão nuclear (setas) associada à citoplasmática (ponta de seta) durante o desenvolvimento. Na presença de ductos excretores, Bax e Bak exibiram importante expressão citoplasmática (Figuras 5.5A e 5.5B, pontas de seta), em que Bax também apresentou expressão nuclear em determinadas células da parede ductal (Figura 5.5A, seta).

A presença de reguladores apoptóticos antagonistas $\mathrm{Bcl}-\mathrm{x}$ e $\mathrm{Bcl}-\mathrm{xL}$ também foi observada durante o desenvolvimento das glândulas salivares humanas, entretanto ilustrando padrões de expressão divergentes. A proteína $\mathrm{Bcl}-\mathrm{x}$ foi majoritariamente detectada na porção citoplasmática das células ductais durante todos os estágios de desenvolvimento (Figuras 5.2K-O) com positividade nuclear ocasionalmente encontrada adjacente à área luminal (Figuras 5.2L, 5.2M, setas). As estruturas ductais mais desenvolvidas presentes na fase de botão terminal evidenciaram expressão citoplasmática de $\mathrm{Bcl}-\mathrm{x}$ mais evidente na camada luminal (Figura $5.5 \mathrm{~N}$ ), ao passo que ductos menores próximos à região acinar exibiram principalmente uma discreta positividade nuclear (Figuras $5.2 \mathrm{~N}, 5.2 \mathrm{O}$, setas). Bcl-xL por sua vez demonstrou importante expressão nuclear em células centrais dos cordões sólidos epiteliais, sendo discretamente associada com positividade citoplasmática na fase inicial de botão (Figura 5.2P) e exclusiva durante a formação dos ductos nas fases pseudoglandular e canalicular (Figuras 5.2Q e 5.2R, setas). Na 
fase mais madura de botão terminal, $\mathrm{Bcl}-\mathrm{x}$ foi completamente negativo em estruturas acinares e ductos intercalados e estriados (Figura 5.2S), contudo ductos excretores exibiram positividade nuclear significativa em células ductais principalmente localizadas na porção luminal (Figuras 5.5C e 5.5D, seta). Imagens comparativas entre a expressão citoplasmática e nuclear de Bcl-x e Bcl-xL são ilustradas em Figuras 5.20 e $5.2 \mathrm{~T}$.

Tabela 5.1 - Análise semi-qualitativa do perfil de expressão de proteínas da família Bcl-2

\begin{tabular}{|c|c|c|c|c|c|c|c|c|c|c|c|c|}
\hline & \multicolumn{6}{|c|}{ Pró-apoptótico } & \multicolumn{6}{|c|}{ Antiapoptótico } \\
\hline & \multicolumn{2}{|c|}{ Bax } & \multicolumn{2}{|c|}{ Bak } & \multicolumn{2}{|c|}{ Bid } & \multicolumn{2}{|c|}{ Bcl-x } & \multicolumn{2}{|c|}{ Bcl-xL } & \multicolumn{2}{|c|}{$\mathrm{Bcl}-2$} \\
\hline & C & $\mathbf{N}$ & C & $\mathbf{N}$ & C & $\mathbf{N}$ & C & $\mathbf{N}$ & $\mathrm{C}$ & $\mathbf{N}$ & C & $\mathbf{N}$ \\
\hline Botão inicial & + & ++ & ++ & + & 0 & 0 & ++ & + & + & + & 0 & 0 \\
\hline Pseudoglandular & ++ & + & ++ & + & 0 & 0 & ++ & + & 0 & + & 0 & 0 \\
\hline Canalicular & ++ & + & ++ & + & 0 & 0 & ++ & + & 0 & ++ & 0 & 0 \\
\hline Botão Terminal & & & & & & & & & & & & \\
\hline Ductos excretores & ++ & + & + & 0 & 0 & 0 & ++ & + & + & ++ & 0 & 0 \\
\hline Ductos menores & + & 0 & + & + & 0 & 0 & + & + & 0 & 0 & 0 & 0 \\
\hline
\end{tabular}

Os resultados estão categorizados em fatores anti e pró-apoptóticos e de acordo com cada estágio morfogenético de glândulas salivares humanas fetais. $\mathrm{C}=$ expressão citoplasmática; $\mathrm{N}$ = expressão nuclear; 0 = negativo; + = fraca expressão; $++=$ forte expressão; Ductos menores $=$ ductos intercalares e estriados. 


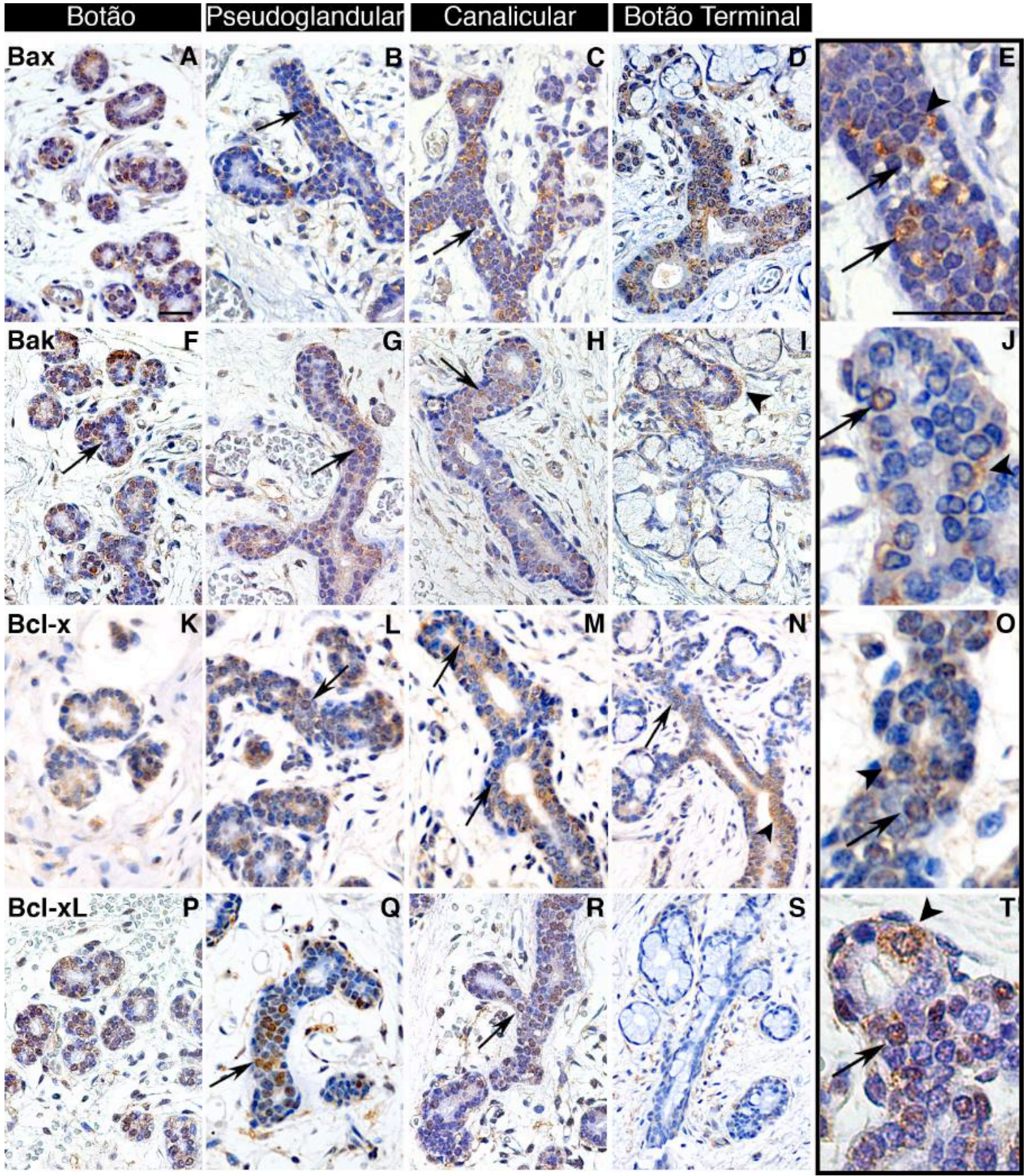

Figura 5.2 - Expressão de proteínas pró e antiapoptóticas da família Bcl-2 durante o desenvolvimento das glândulas salivares humanas. (A, B, C, D) Expressão de Bax. Em geral, a presença de Bax citoplasmática foi mais prevalente durante todas as fases de desenvolvimento (A-D), porém determinadas células centrais dos cordões sólidos epiteliais exibiram a proteína na porção nuclear nas fases iniciais (B, C, setas). (F, G, H, I) Expressão de Bak. Proeminente positividade nuclear de Bak nas áreas centrais dos cordões sólidos epiteliais ( $F, G, H$, setas). Na fase terminal de botão, observa-se exclusivamente expressão citoplasmática em ductos estriados e intercalares (I). (K, L, M, N) Expressão de Bcl-x. Todas as fases de desenvolvimento exibiram predominante localização citoplasmática de $\mathrm{Bcl}-\mathrm{x}(\mathrm{K}-\mathrm{N})$, enquanto a expressão nuclear foi restrita às fases finais de canalização e de diferenciação em apenas algumas células ductais adjacentes ao espaço luminal ( $L, M, N$, setas). (P, Q, R, S) Expressão de $B c l-x L$. Predominante localização nuclear de $\mathrm{Bcl}-\mathrm{xL}$ nas áreas luminais presuntivas durante todas as fases de desenvolvimento $(P-R)$, especialmente nos estágios de formação ductal $(Q, R$, setas). Completa ausência de $\mathrm{Bcl}-\mathrm{xL}$ na fase de botão terminal (S). (E, J, O, T) Imagem ampliada da expressão nuclear e citoplasmática de $\operatorname{Bax}(E)$, Bak $(J)$, Bcl-x $(O)$ e Bcl-xL $(T)$. Setas representam positividade nuclear, pontas de seta indicam citoplasmática. Escala $=30 \mu \mathrm{m}$. 


\subsubsection{Resultados imunoistoquímicos - Caspases}

Um dos reguladores mais importantes da cascata de sinalização apoptótica corresponde ao grupo de caspases, cuja presença nas fases de desenvolvimento das glândulas salivares humanas foi avaliada através da detecção da expressão de proteínas efetoras e iniciadoras. Caspases-3, -6 e -7 representam as principais caspases efetoras da via apoptótica, enquanto caspase- 9 representa a protease iniciadora. Assim a análise semi-qualitativa dessas proteínas foi realizada de acordo com cada estágio morfogenético das glândulas salivares em desenvolvimento, e os resultados estão descritos na Tabela 5.2. Particularmente, a expressão de caspase3 foi investigada em sua forma ativada uma vez que atualmente representa o marcador padrão de detecção de atividade apoptótica. Curiosamente, caspase-3 clivada foi completamente negativa em todos os espécimes analisados e durante todas as fases de desenvolvimento glandular (Figuras 5.3A-D). Em contrapartida, a presença de caspase-6, -7 e -9 foi detectada durante quase todos os estágios (Figuras 5.3E-S).

Majoritariamente a expressão de caspase-6 exibiu localização nuclear desde a fase de botão inicial até o estágio de canalização nas porções centrais dos botões e cordões epiteliais em formação (Figuras 5.3E-I, setas). A expressão citoplasmática se torna evidente na fase de botão terminal na região de ductos intercalares (Figura $5.3 \mathrm{H}$, ponta de seta) ao passo que os ductos estriado e excretor ainda expressaram caspase-6 nuclear mais proeminente (Figuras $5.3 \mathrm{H}$ e $5.5 \mathrm{E}$, seta). Caspase-7 exibiu um padrão de expressão principalmente nuclear em células epiteliais nas fases iniciais (Figura 5.3J-L) com evidência no estágio pseudoglandular (Figura 5.3K, seta). Os ductos estriado e excretor também exibiram marcação nuclear mais prevalente que citoplasmática para caspase-7, enquanto ductos menores associados aos botões terminais revelaram caspase-7 citoplasmática (Figura 5.3M, pontas de seta). Adicionalmente, caspase-7 também foi observada em núcleo de células caracteristicamente apoptóticas em botão epitelial (Figura 5.3N, seta), e em ductos excretoras durante a fase final de desenvolvimento glandular houve apenas moderada expressão nuclear (Figura 5.5F, seta). Em padrão de expressão similar à caspase-6, caspase-9 foi somente nuclear nas fases iniciais (Figuras 5.30, 5.3P), enquanto discreta e localizada positividade citoplasmática foi detectada nas fases de 
canalização (Figuras 5.3Q, 5.3S, ponta de seta) e botão terminal (Figura 5.3R, ponta de seta) paralelamente à presença nuclear (Figura 5.3S, seta). Ductos excretores mais desenvolvidos em fase terminal de desenvolvimento mantiveram marcação nuclear mais intensa que citoplasmática em todas as camadas epiteliais (Figura $5.5 G)$. 
Tabela 5.2 - Análise semi-qualitativa do perfil de expressão de caspases em glândulas salivares humanas em desenvolvimento

\begin{tabular}{|c|c|c|c|c|c|c|c|c|}
\hline & \multirow{2}{*}{\multicolumn{2}{|c|}{$\begin{array}{l}\text { Iniciadora } \\
\text { Caspase-9 }\end{array}$}} & \multicolumn{6}{|c|}{ Efetoras } \\
\hline & & & \multicolumn{2}{|c|}{ Caspase-6 } & \multicolumn{2}{|c|}{ Caspase-7 } & \multicolumn{2}{|c|}{ Caspase-3 cl. } \\
\hline & C & $\mathbf{N}$ & C & $\mathbf{N}$ & C & $\mathbf{N}$ & C & $\mathbf{N}$ \\
\hline Botão inicial & 0 & + & 0 & + & + & + & 0 & 0 \\
\hline Pseudoglandular & 0 & + & 0 & + & + & ++ & 0 & 0 \\
\hline Canalicular & + & ++ & 0 & + & + & + & 0 & 0 \\
\hline \multicolumn{9}{|l|}{ Botão Terminal } \\
\hline Ductos excretores & + & ++ & + & ++ & 0 & + & 0 & 0 \\
\hline Ductos menores & + & + & + & + & + & 0 & 0 & 0 \\
\hline
\end{tabular}

Os resultados estão de acordo com os estágios morfogenéticos e ilustram a expressão de caspase-9 (iniciadora) e caspase-3 clivada e caspases-6 e -7 (efetoras). $\mathrm{C}=$ expressão citoplasmática; $\mathrm{N}=$ expressão nuclear; 0 = negativo; $+=$ fraca expressão; $++=$ forte expressão; Ductos menores $=$ ductos intercalares e estriados. 
Botão Pseudoglandular Canalicular Botão Terminal

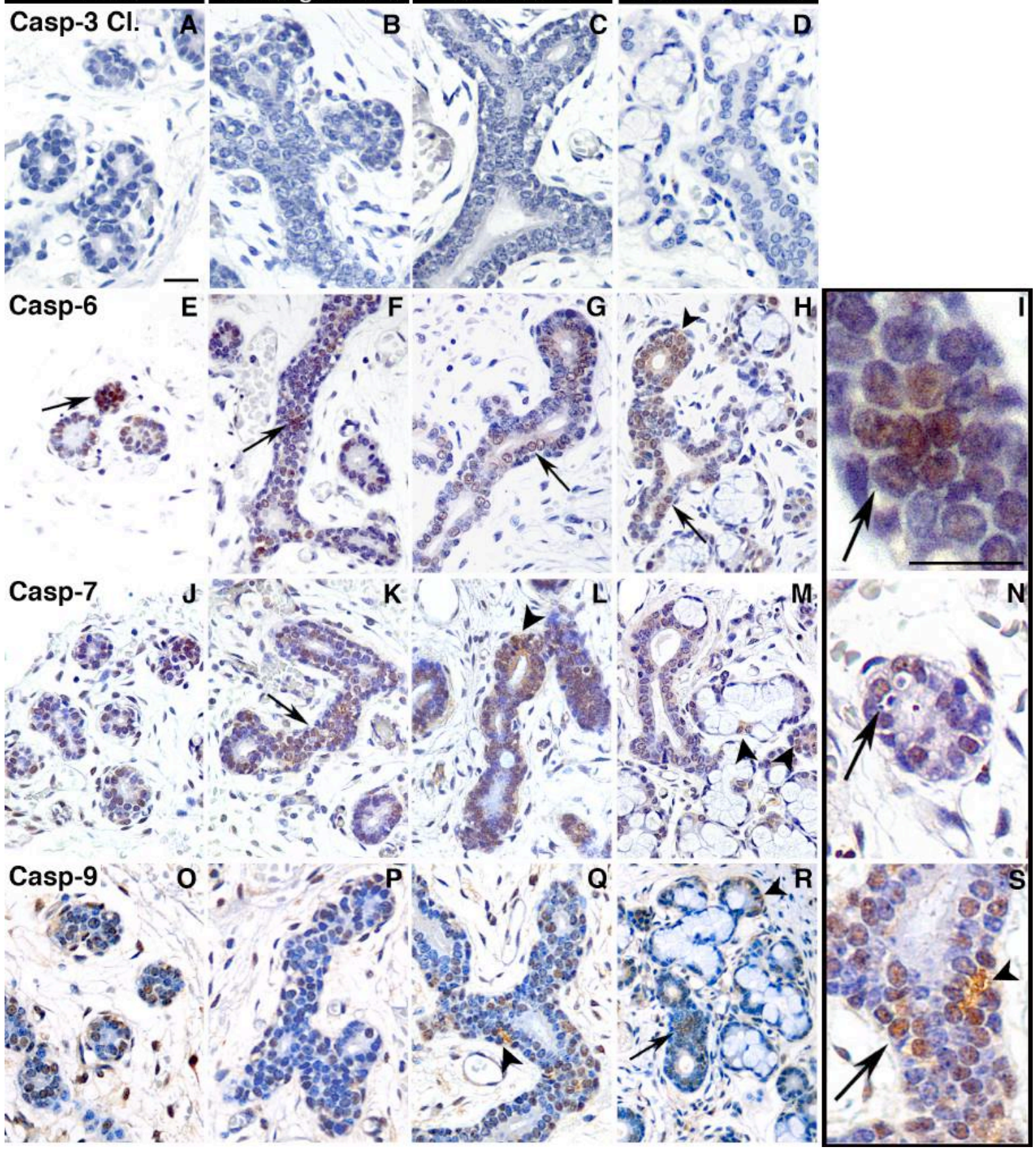


Figura 5.3 - Perfil de expressão de caspases efetoras e iniciadora durante o desenvolvimento das glândulas salivares humanas. (A, B, C, D) Caspase-3 clivada foi negativa em todos os espécimes analisados. (E, F, G, H, I) Expressão de caspase-6. Apenas positividade nuclear foi detectada nos cordões epiteliais durante os estágios iniciais de desenvolvimento ( $E, F$, setas), enquanto as fases canalicular e botão terminal também exibiram expressão citoplasmática nas células ductais ( $G, H$, setas e pontas de seta). A expressão nuclear nos estágios iniciais é particularmente observada em células centrais dos cordões sólidos em desenvolvimento (I, seta). (J, K, L, M, N) Expressão de caspase-7. Durante todo os estágios, caspase-7 foi detectada em ambos os compartimentos nuclear e citoplasmático (J-M), sendo a expressão nuclear predominante na fase pseudoglandular $(\mathrm{J})$ e a citoplasmática mais evidente em ductos mais desenvolvidos presentes a partir da fase canalicular ( $L$, ponta de seta). Em maior magnificação, a expressão nuclear de caspase-7 foi observada em célula caracteristicamente apoptótica em um ducto em formação $(\mathrm{N}$, seta). ( $\mathbf{O}, \mathbf{P}, \mathbf{Q}, \mathbf{R}, \mathbf{S})$ Expressão de caspase-9. Durante as fases iniciais de desenvolvimento, caspase-9 foi positiva somente na porção nuclear das células epiteliais $(O, P)$, enquanto a expressão citoplasmática ocorreu a partir das fases mais tardias em regiões localizadas $(Q, R$, pontas de seta). Imagem ampliada de ducto em desenvolvimento ilustra a correlação da presença de caspase-9 em núcleo ( $S$, seta) e citoplasma ( $S$, ponta de seta). Setas representam positividade nuclear, pontas de seta indicam citoplasmática. Escala = $30 \mu \mathrm{m}$.

\subsubsection{Resultados Imunoistoquímicos - Apoptossomo e survivina}

A formação do complexo apoptossomo é um passo fundamental para a ativação do mecanismos apoptótico intrínseco, sendo composto por Apaf-1 e Citocromo C. Durante o desenvolvimento das glândulas salivares humanas, ambos foram observados durante todos os estágios morfogenéticos (Tabela 5.3). A expressão de Apaf-1 revelou-se nuclear e citoplasmática em células ductais tanto em estruturas precoces quanto maduras, revelando o padrão nuclear mais proeminente nas fases iniciais (Figuras 5.4A-C). Em regiões localizadas como ductos intercalares em proximidade com ácinos diferenciados na fase terminal de botão (Figura 5.4D, ponta de seta) e determinadas células em ductos estriados (Figura 5.3C, ponta de seta) observa-se a presença de Apaf-1 citoplasmática. Em maior detalhe é possível distinguir a marcação nuclear mais proeminente que citoplasmática em ducto precoce (Figura 5.4E, setas), enquanto ductos excretores maduros em fase terminal de botão exibem expressão nuclear mais pronunciada (Figura $5.5 \mathrm{H}$, seta). Diferentemente de Apaf-1, a expressão de Citocromo $\mathrm{C}$ foi exclusivamente citoplasmática em todos os estágios morfogenéticos das glândulas salivares humanas fetais, exibindo maior prevalência nas fases pseudoglandular e canalicular (Figuras 5.4F-J). Ductos maduros em fase terminal de botão revelaram 
expressividade citoplasmática mais prevalente em ductos excretores comparados com ductos menores estriado e intercalar (Figuras 5.4D, 5.4J e 5.5I).

O inibidor apoptótico survivina demonstrou uma significativa alternância entre o padrão de expressão de estruturas epiteliais precoces e maduras. A prevalência citoplasmática foi observada principalmente durante desenvolvimento inicial, como em ilhas epiteliais da fase de botão (Figura 10K, ponta de seta) e porções distais dos cordões em proliferação (Figuras 10L, 10M e 100, pontas de seta). Em contraste, importante expressão de survivina foi encontrada no compartimento nuclear de células ductais em fases morfogenéticas mais avançadas, tanto em ductos intercalares em proximidade com os ácinos como em ductos maiores estriado e excretor (Figuras $5.4 \mathrm{M}, 5.4 \mathrm{~N}, 5.40$ e $5.5 \mathrm{~J}$, setas). 
Tabela 5.3 - Análise semi-qualitativa da expressão do inibidor de apoptose survivina e dos membros do complexo apoptossomo Apaf-1 e citocromo C de acordo com os estágios morfogenéticos das glândulas salivares humanas

\begin{tabular}{|c|c|c|c|c|c|c|}
\hline & \multirow{2}{*}{\multicolumn{2}{|c|}{$\frac{\text { IAP }}{\text { Survivina }}$}} & \multicolumn{4}{|c|}{ Apoptossomo } \\
\hline & & & \multicolumn{2}{|c|}{ Apaf-1 } & \multicolumn{2}{|c|}{ Citocromo C } \\
\hline & C & $\mathbf{N}$ & C & $\mathbf{N}$ & C & $\mathbf{N}$ \\
\hline Botão inicial & ++ & + & 0 & ++ & + & 0 \\
\hline Pseudoglandular & ++ & + & + & ++ & ++ & 0 \\
\hline Canalicular & + & ++ & + & + & ++ & 0 \\
\hline Botão Terminal & & & & & & \\
\hline Ductos excretores & 0 & ++ & ++ & ++ & + & 0 \\
\hline Ductos menores & 0 & ++ & + & + & 0 & 0 \\
\hline
\end{tabular}

$\mathrm{C}=$ expressão citoplasmática; $\mathrm{N}=$ expressão nuclear; $0=$ negativo; $+=$ fraca expressão; ++ = forte expressão; Ductos menores = ductos intercalares e estriados. 


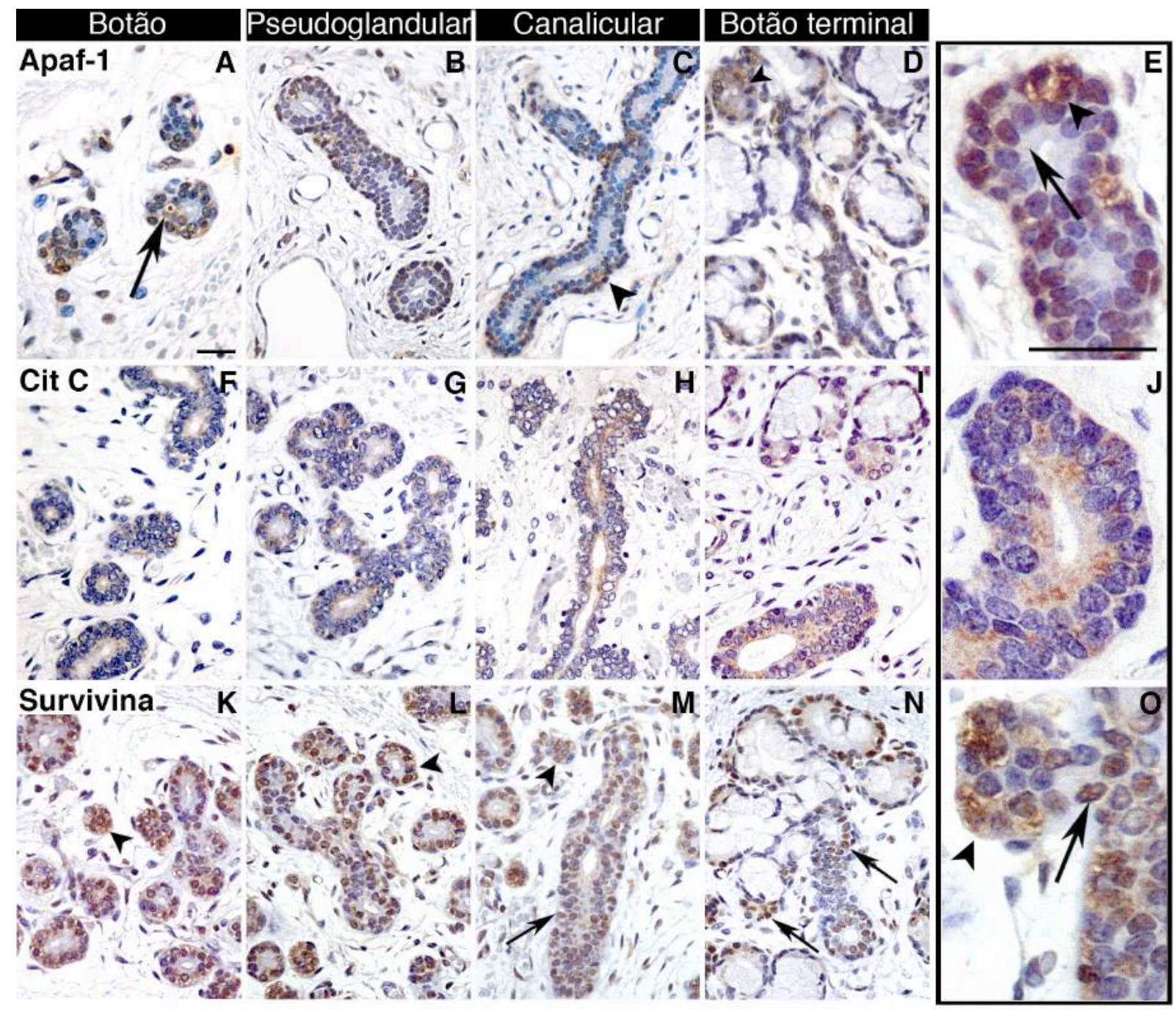

Figura 5.4 - Expressão de componentes do complexo apoptossomo e do inibidor de apoptose survivina durante o desenvolvimento das glândulas salivares humanas. (A, B, C, D, E) Expressão de Apaf-1. Estágios iniciais revelam expressão nuclear mais proeminente que citoplasmática nas células epiteliais $(A, B, C)$, sendo encontrada em associação a célula caracteristicamente apoptótica em fase prematura ( $A$, seta). A marcação citoplasmática pode ser detectada em regiões localizadas nos longos cordões epiteliais durante as fases intermediárias $(B, C)$ e particularmente em ductos intercalares na fase tardia ( $D$, ponta de seta). Imagem ampliada ilustra ambas as localizações intracelulares de Apaf-1 em ducto em formação (E, seta e ponta de seta). $(\mathbf{F}, \mathbf{G}, \mathbf{H}, \mathbf{I}, \mathbf{J})$ Expressão de Citocromo C. Exclusiva positividade citoplasmática foi observada durante todas as fases de desenvolvimento glandular, sendo mais proeminente nas porções celulares luminais $(F-J)$. (K, L, M, N, O) Expressão de survivina. Um padrão de expressão citoplásmico foi prevalente nas estruturas mais precoces $(\mathrm{K}, \mathrm{L}$, pontas de seta) que se revelou proeminentemente nuclear em fases mais avançadas de desenvolvimento ( $\mathrm{M}, \mathrm{N}$, setas). Detalhe de ducto em formação associado com estrutura acinar indiferenciada evidenciando mais expressão citoplasmática nos botões epiteliais $(\mathrm{O}$, ponta de seta) comparado com a região de ductos (O, seta). Setas representam positividade nuclear, e pontas de seta indicam citoplasmática. Escala $=30 \mu \mathrm{m}$. 


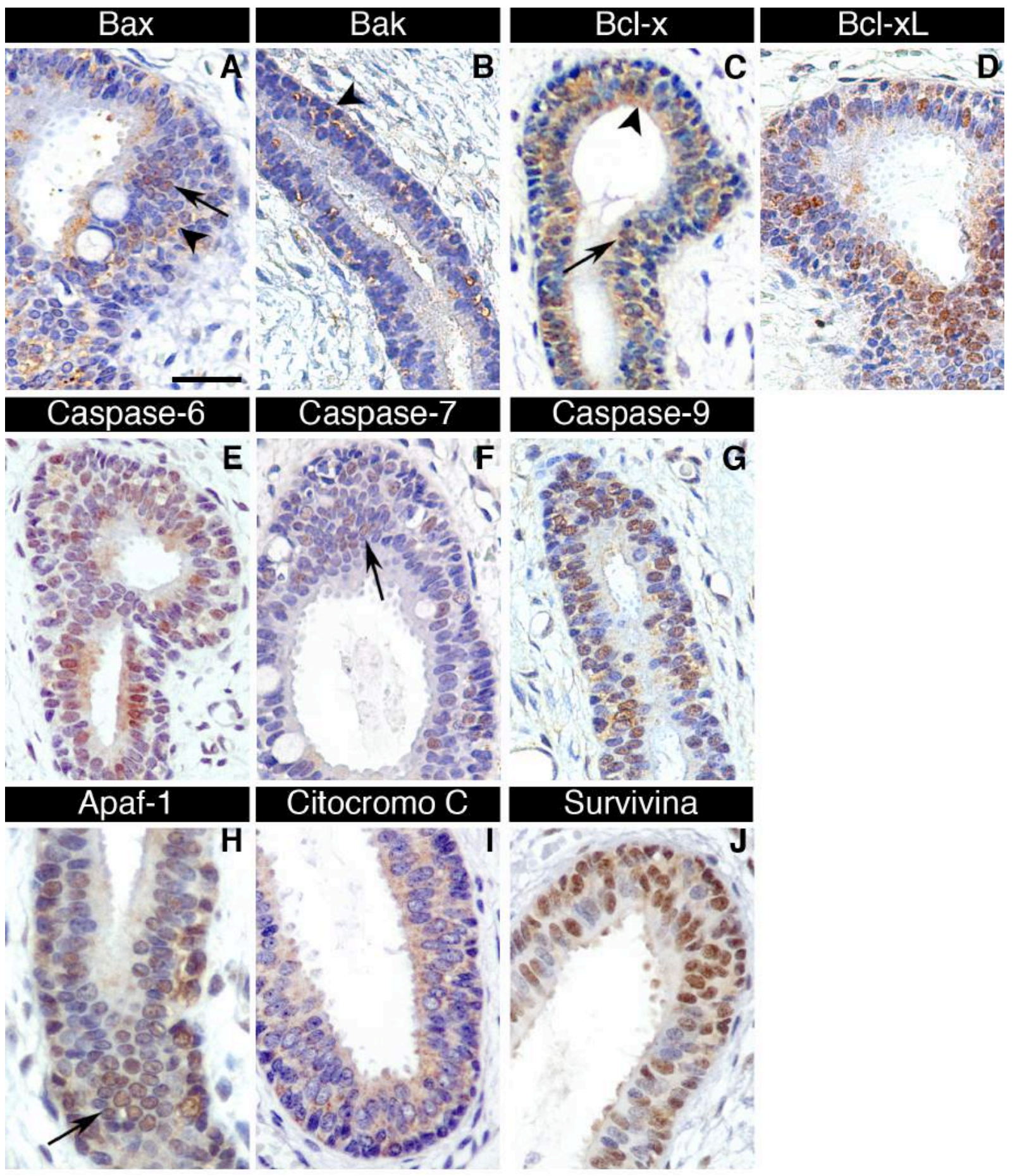


Figura 5.5 - Expressão de proteínas envolvidas no mecanismo apoptótico intrínseco em ductos excretores de glândulas salivares humanas em fase tardia de desenvolvimento. (A, B, C, D) Expressão de proteínas da família Bcl-2 em ductos excretores de glândulas salivares humanas fetais. A presença de Bax foi predominantemente citoplasmática ( $A$, ponta de seta) com focos de expressão nuclear (A, seta), enquanto Bak revelou-se somente em compartimento citoplasmático de células basais dos ductos excretores ( $B$, ponta de seta). Membros antiapoptóticos Bcl-x e Bcl-xL foram ambos detectados em região nuclear e citoplasmática das células ductais, porém $\mathrm{Bcl}-\mathrm{x}$ foi mais proeminente em citoplasma (C, ponta de seta) quando comparado com a expressão nuclear (C, seta), ao passo que $\mathrm{Bcl}-\mathrm{xL}$ apresentou-se mais expressivo em núcleo, principalmente na camada luminal (D). (E, F, G) Expressão das cisteínas caspases-6, -7 e -9. A marcação de todas as caspases foi mais proeminente na porção nuclear das células ductais, sendo caspase-7 exclusivamente nuclear ( $F$, seta). Caspases-6 e -9 também exibiram discreta expressão citoplasmática em determinadas células ductais $(E, G)$. Setas representam positividade nuclear, e pontas de seta indicam citoplasmática. Escala $=30 \mu \mathrm{m}$.

\subsection{ANÁLISE MORFOLÓGICA DA ATIVIDADE APOPTÓTICA DURANTE O DESENVOLVIMENTO DE GLÂNDULAS SALIVARES DE CAMUNDONGO}

A evidência da presença de proteínas reguladoras da apoptose intrínseca durante a formação de glândulas salivares humanas direcionou o presente estudo a avaliar também a expressão de marcadores apoptóticos em glândulas salivares embrionárias de camundongo. Tal fato foi consequência de ser fundamental caracterizar temporalmente a atividade apoptótica durante a formação glandular, principalmente durante a abertura do espaço luminal dos ductos, uma vez que o estudo temporal em humanos é limitado devido à escassa disponibilidade de espécimes em estágios precoces. Dessa maneira, a análise da expressão e função apoptótica foi realizada em estágios cruciais da formação ductal das glândulas salivares através de marcadores específicos do processo de morte celular.

Os estágios analisados basearam-se no período específico de formação do espaço luminal dos ductos glandulares, e a expressão do marcador de morte celular Lysotracker e de específicos para atividade apoptótica Caspase-3 clivada e TUNEL foi investigada (Figura 5.6). Imagens em HE ilustram a morfologia correspondente a cada estágio glandular (Figuras 5.6A, 5.6E, 5.6I), enquanto o marcador E-caderina foi utilizado para evidenciar a porção epitelial nos diferentes estágios (Figuras 5.6B, $5.6 \mathrm{~F}, 5.6 \mathrm{~J}$ ), auxiliando na identificação das estruturas glandulares. O primórdio do primeiro ducto glandular ainda sólido é observado a partir da fase de botão inicial em 
E12.5, apenas com uma sutil invaginação proveniente do epitélio oral (Figuras 5.6A, 5.6M). O estágio pseudoglandular em E13.5 já exibe pequeno espaço luminal formado (Figuras 5.6E, 5.6O) ao passo que E14.5 foi determinada a fase mais tardia desta análise por já apresentar espaços luminais bem formados.

A específica atividade apoptótica durante o desenvolvimento glandular entre as fases de formação luminal foi confirmada através da expressão células positivas para Caspase-3 clivada e TUNEL (Figuras 5.6C, 5.6G, 5.6K e 5.6D, 5.6H, 5.6L respectivamente). Uma importante evidência de ambos os marcadores foi encontrada na região central do cordão epitelial primário em $E 12.5$, na região presuntiva do espaço luminal (Figuras 5.6C, 5.6D, setas). No estágio embrionário seguinte em E13.5, a presença de células apoptóticas no interior do ducto principal e em região localizada do epitélio oral foi mais expressiva (Figuras 5.6G, 5.6H, setas), ao passo que escassa positividade foi detectada em ductos mais desenvolvidos em E14.5 (Figuras 5.6K, 5.6L). A presença de células em processo de morte celular não especificamente por apoptose também foi investigada através da expressão de Lysotracker, que foi detectada no cordão epitelial em E12.5 e E13.5 (Figuras 5.6N, 5.6P). Determinadas células centrais do ducto submandibular no estágio E13.5 exibiram colocalização de Lysotracker e caspase-3 clivada (Figuras 5.6S, 5.6T). No ducto da glândula sublingual entretanto houve somente a expressão de caspase-3 clivada ao longo de toda a estrutura, uma vez que apresenta desenvolvimento mais tardio quando comparada à submandibular (Redman; Ball, 1978). 


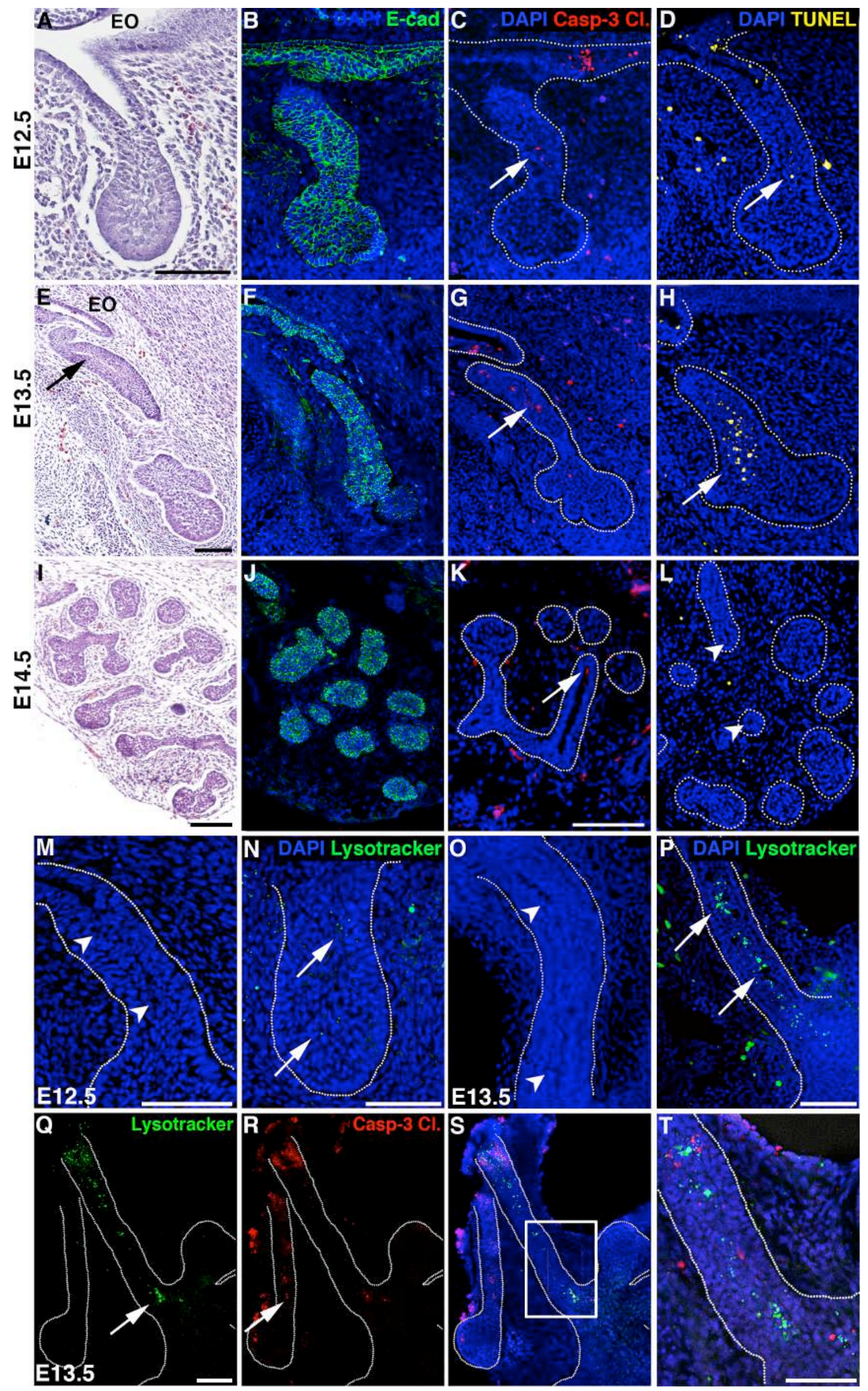


Figura 5.6 - Comparação da expressividade de marcadores apoptóticos em glândulas submandibulares de camundongo. (A, B, C, D) E12.5. (E, F, G, H) E13.5. (I, J, K, L) E14.5. (M, N, O, P) Ducto principal da glândula submandibular. (Q, R, S, T) Dupla marcação imunofluorescente em glândula salivar em estágio E13.5. (A, E, I) Coloração em HE de secções sagitais de glândulas salivares de E12.5 a E14.5. Seta em E evidencia a presença precoce de espaço luminal em E13.5. (B, F, J) Expressão de Ecaderina (verde) em epitélio embrionário evidenciando a porção glandular. (C, G, K, S) Expressão de caspase-3 clivada durante os estágios iniciais de formação luminal na região central de ductos e cordões epiteliais (setas). (D, H, L) Células TUNEL positivas (em amarelo) apresentam padrão de expressão similar ao de caspase-3 clivada, localizadas majoritariamente no estágio E13.5 na região central do ducto principal $(H)$. $(\mathbf{M}, \mathbf{O})$ Marcação com DAPI ilustra a presença de células com núcleo condensado caracteristicamente apoptótico na área presumidamente luminal (pontas de seta). (N, P) Células ductais de glândula submandibular em processo de morte celular apresentando expressão de Lysotracker em região presuntiva de espaço luminal (setas). (Q, R, S, T) Comparação entre a expressão de caspase-3 clivada (em vermelho) e Lysotracker (em verde) em dupla marcação em glândula submandibular em E13.5. Células positivas para Lysotracker encontram-se alinhadas ao longo do ducto submandibular em formação (setas), sendo por vezes colocalizadas com caspase-3 clivada (S, T) e completamente ausente em ducto sublingual $(R$, seta). Setas indicam células positivas para determinado marcador, e pontas de seta apontam espaço luminal em formação. EO = epitélio oral, escala $=100 \mu \mathrm{m}$.

Visto a importante expressão de células apoptóticas nas regiões presuntivas de espaço luminal, buscou-se identificar se tais estruturas são de fato correspondentes às futuras regiões ductais. Para tanto, utilizou-se o marcador Citoqueratina $7(\mathrm{~K} 7)$, que expressa a localização precoce dos ductos em formação (Figura 5.7) como observada anteriormente em glândulas salivares em desenvolvimento (Walker et al., 2008) e em células menos diferenciadas da ramificação ductal pancreática (Bouwens, 1998). No estágio de botão inicial E12.5 a expressão de $\mathrm{K} 7$ foi observada nas células centrais dos cordões epiteliais (Figura 5.7A, setas) com absoluta ausência nos botões epiteliais (Figura 5.7A, ponta de seta). Na fase seguinte $\mathrm{E} 13.5$, células $\mathrm{K} 7$ positivas também são observadas na porção luminal do ducto principal, contornando o espaço luminal em formação (Figura 5.7B, seta). O padrão de expressão manteve-se no estágio E14.5 em período de expansão dos espaços luminais, exibindo importante positividade em células ductais mais desenvolvidas e em epitélio oral (Figuras 5.7C, 5.7D, setas). 

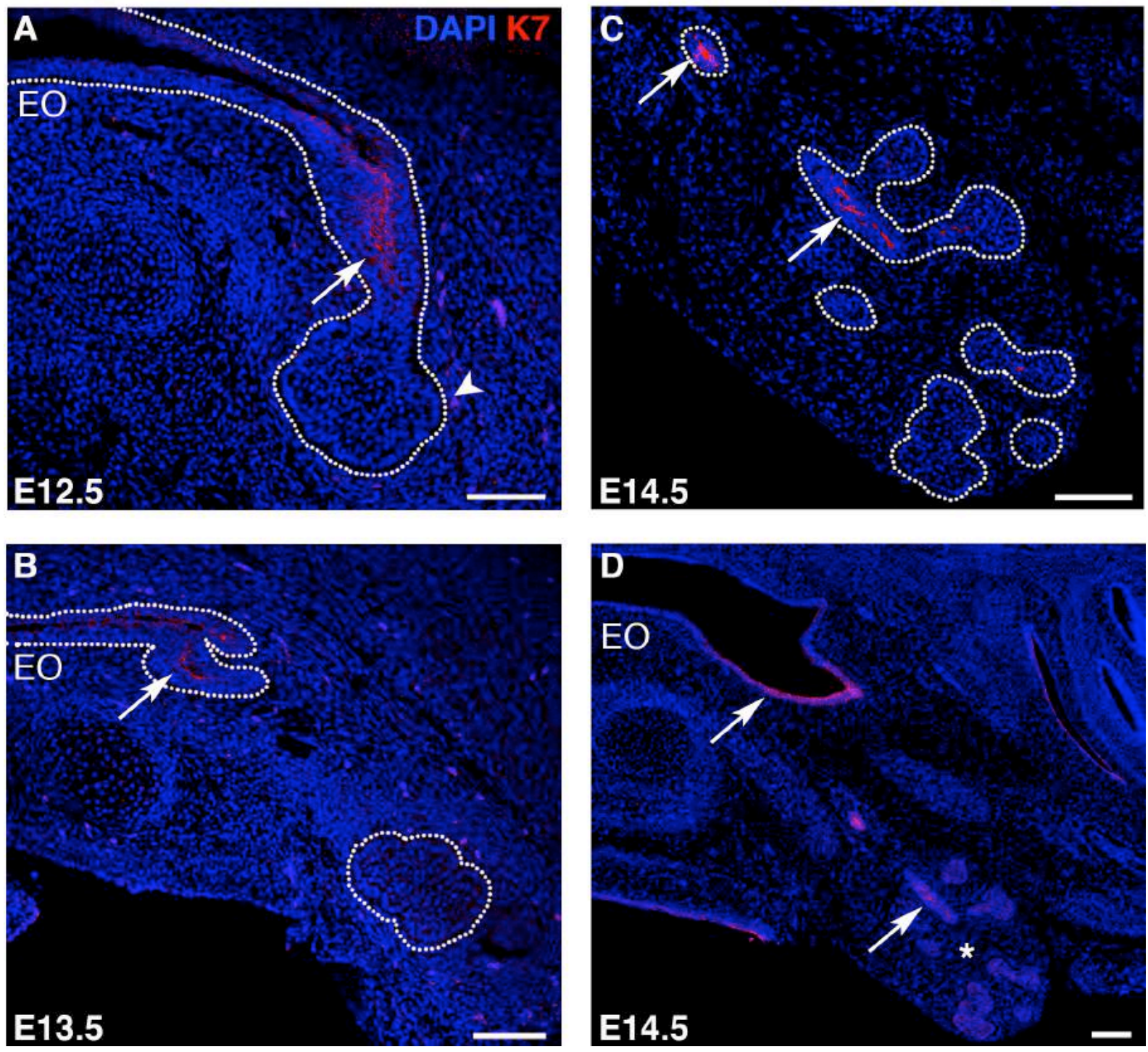

Figura 5.7 - Regiões correspondentes ao presuntivo espaço luminal glandular exibem importante marcação de citoqueratina 7 (K7). (A) Células ductais K7 positivas foram localizadas no centro do cordão epitelial em estágio precoce de desenvolvimento em E12.5 (setas), sendo totalmente ausente em botão (ponta de seta). (B) A expressão da proteína $\mathrm{K} 7$ mantém-se restrita em porção luminal de células ductais em estágio pseudoglandular (seta). (C, D) Em estágio mais avançado E14.5, K7 permanece na região apical das células ductais mais desenvolvidas $(C, D$, setas) e em epitélio oral (D, seta). Asterisco indica a glândula submandibular. Escala $=100 \mu \mathrm{m}$.

\subsection{ANÁLISE FUNCIONAL DA INIBIÇÃO APOPTÓTICA DURANTE O DESENVOLVIMENTO DE GLÂNDULAS SALIVARES DE CAMUNDONGO}

No intuito de se obter um melhor entendimento acerca da função apoptótica para a formação das glândulas salivares, experimentos funcionais foram realizados 
em culturas in vitro de glândulas salivares embrionárias de camundongo, uma vez que o desenvolvimento ex vivo é reconhecidamente compatível com 0 in vivo (Borghese, 1950) Partindo do princípio de que as caspases são os reguladores mais importantes da cascata de sinalização apoptótica intrínseca e extrínseca (Degterevet al., 2003; Taylor et al., 2008), promoveu-se a inibição de todas as caspases a partir de estágios iniciais da formação glandular que permitiu a visualização dos efeitos da ausência de apoptose durante esse processo.

Baseando-se na análise morfológica das fases de desenvolvimento das glândulas salivares realizada primeiramente, observa-se que o início da formação do espaço luminal dos ductos glandulares em associação com a presença de células em apoptose ocorre em estágio precoce E12.5, antes mesmo do que se tem atualmente publicado na literatura (Jaskoll et al., 2001; Tucker, 2007). Dessa maneira, analisou-se inicialmente o efeito do bloqueio de caspases em glândulas salivares de camundongo albino em estágio de botão inicial em E12.5 a uma concentração de $100 \mu \mathrm{M}$ por $72 \mathrm{~h}$. Após esse período, as culturas dos grupos controle atingiram a formação do botão primário que apresentou um início de ramificação, conectado ao epitélio oral por um estreito cordão epitelial. Em contraste, as culturas do grupo experimental exibiram um cordão mais espesso (Figura 5.8A, setas). Para avaliar o efeito do inibidor na formação glandular, o diâmetro ductal de cada glândula foi mensurado em ambos os grupos controle e experimental a $0 \mathrm{~h}$ de cultura e a cada $24 \mathrm{~h}$, que resultou em uma diferença estatisticamente significativa desde as primeiras horas de cultura (Figura 5.8B) $(\mathrm{N}=18, \mathrm{p}<0.05)$.

As culturas do grupo controle de glândulas salivares em E12.5 exibiram um retardo de desenvolvimento mais acentuado comparadas com as culturas sem DMSO. Glândulas salivares cultivadas somente em meio de cultura DMEM exibem um padrão desenvolvimento glandular normal, com ductos bem formados e ácinos ramificados bem diferenciados após o mesmo período de cultivo, enquanto a adição de DMSO nos grupos controle já é suficiente para afetar a formação das glândulas, principalmente a ramificação (Figura 5.8A). Esse efeito indica que tal estágio precoce é consideravelmente sensível a baixos níveis desse veículo, não resistindo portanto à concentração máxima de $200 \mu \mathrm{M}$, o que não permitiu a observação dos efeitos da inibição apoptótica em todos os aspectos do desenvolvimento. Para tanto, 
promoveu-se então a inibição funcional de glândulas em estágios mais avançados, que seriam mais resistentes aos efeitos do veículo DMSO e do inibidor. 
A
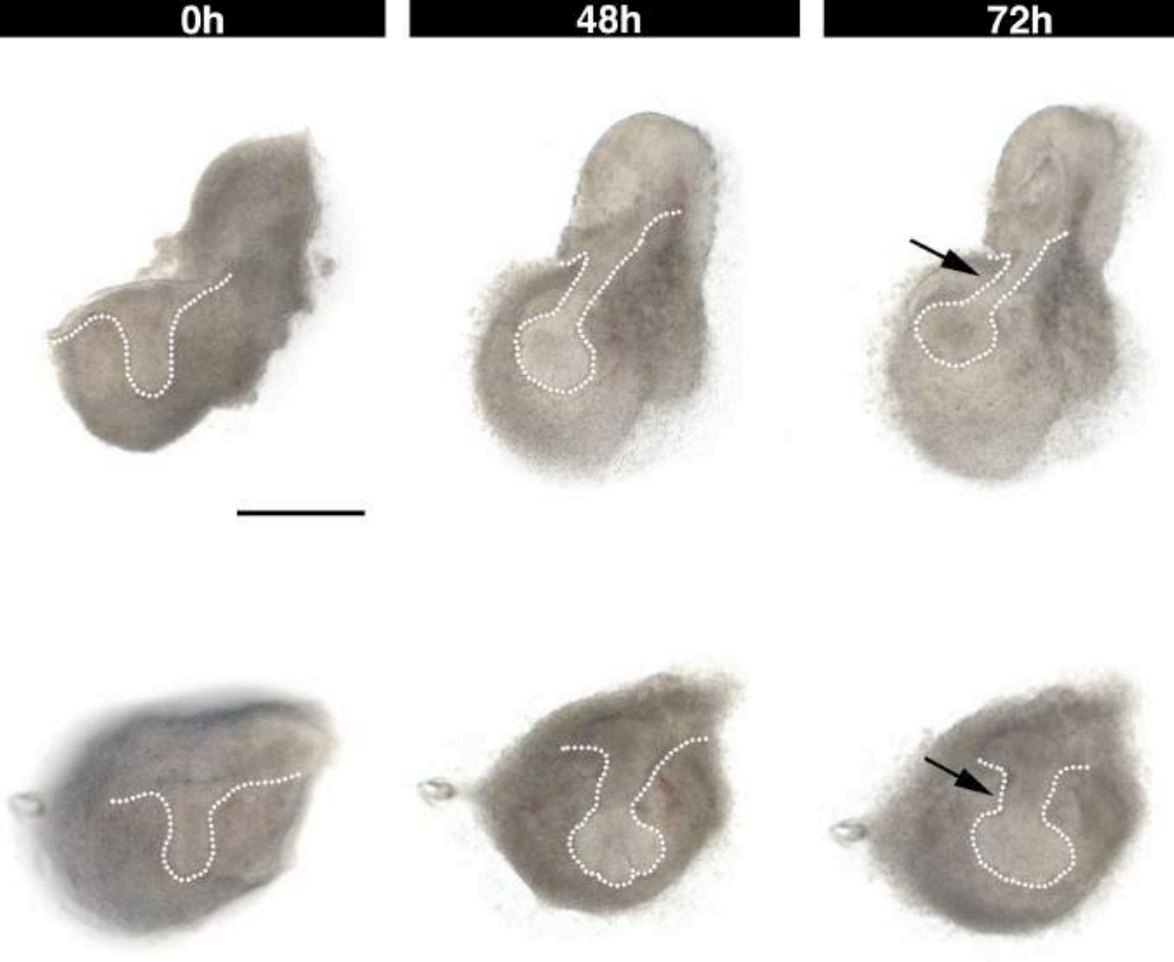

B

$\mathrm{E} 12.5+72 \mathrm{~h}$ a $100 \mu \mathrm{M}$

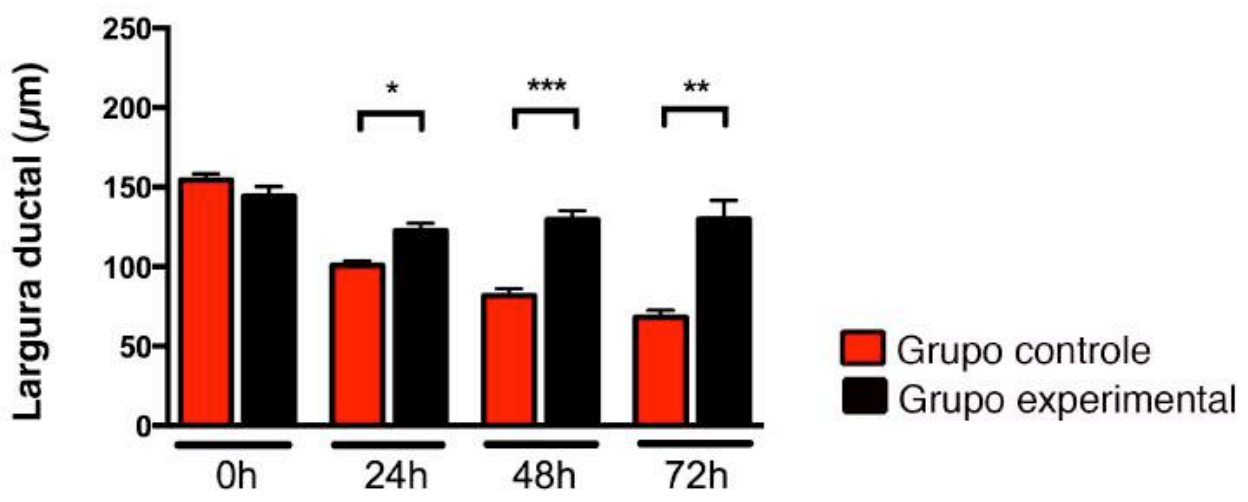

Período de cultura

Figura 5.8 - Alteração morfológica decorrente da inibição de caspases em fase precoce de desenvolvimento glandular. (A) Glândulas salivares em fase de botão inicial cultivadas por $72 \mathrm{~h}$ sem a adição de nenhum reagente (normal) e a uma concentração de $100 \mu \mathrm{M}$ de DMSO e Z-VAD-FMK. Defeitos na morfologia glandular já são observados somente na presença do veículo DMSO, que exibe retardo severo de desenvolvimento em comparação com o grupo normal. Entre o grupo controle (DMSO) e experimental (ZVAD-FMK), ductos com largura mais ampla são evidentes a partir de $48 \mathrm{~h}$ de cultura na presença do pan-inibidor de caspases (setas). Escala $=500 \mu \mathrm{m}$. (B) Análise estatística pareada evidencia a diferença da largura ductal entre os grupos controle e experimental das glândulas salivares em fase precoce. Um aumento estatisticamente significativo da largura dos ductos submandibulares no grupo experimental foi observado a partir de $24 \mathrm{~h}$ de cultivo comparado ao grupo controle $\left(\mathrm{N}=18 ;{ }^{*} \mathrm{p}=0.02\right.$; ${ }^{* *} \mathrm{p}$ $=0.008 ;{ }^{* * *} p=0.0006$. A margem de erro representa erro médio padrão). 
Concentrações graduais de 100, 150 e 200 $\mu \mathrm{M}$ foram utilizadas em culturas de glândulas salivares a partir dos estágios E13.5 e E14.5. A adição de do pan-inibidor Z-VAD-FMK a culturas na fase pseudoglandular (E13.5) resultou em efeitos semelhantes aos observados nas culturas de glândulas mais precoces, exibindo ductos mais amplos (Figura 5.9A, setas) e defeitos em ramificação da região acinar (Figura 5.8A, pontas de seta). Em contrapartida, a inibição de apoptose a partir do estágio canalicular E14.5 não resultou em nenhuma diferença tanto na formação ductal como na ramificação acinar (Figura 5.10, setas), corroborando com os resultados observados anteriormente. As consequências da inibição apoptótica na fase pseudoglandular (E13.5) foi associado a um efeito dose-dependente, uma vez que a concentração de $150 \mu \mathrm{M}$ exibiu resultados estatisticamente significativos em

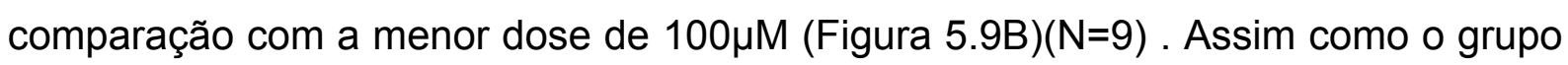
de glândulas mais precoces a E12.5, o fenótipo obtido na região ductal também foi mensurado através da comparação da largura dos ductos de ambos os grupos, resultando em diferença estatisticamente significativa após $72 \mathrm{~h}$ de cultivo em doses mais elevadas do inibidor (Figura 5.9C)(N=9). A influência da inibição apoptótica também revelou importante defeitos em ramificação acinar, impedindo as porções distais a proliferar e diferenciar-se normalmente (Figura 5.9A, pontas de seta). Essa redução foi mensurada para cada espécime (Mean Spooner Ratio - número total de botões a x horas/número total de botões a $0 \mathrm{~h}$ ) de acordo com cada concentração após $48 \mathrm{~h}$, exibindo redução significativa do número de ramificações a 150 e $200 \mu \mathrm{M}$ (Figura 5.9D)(N=9). 
A
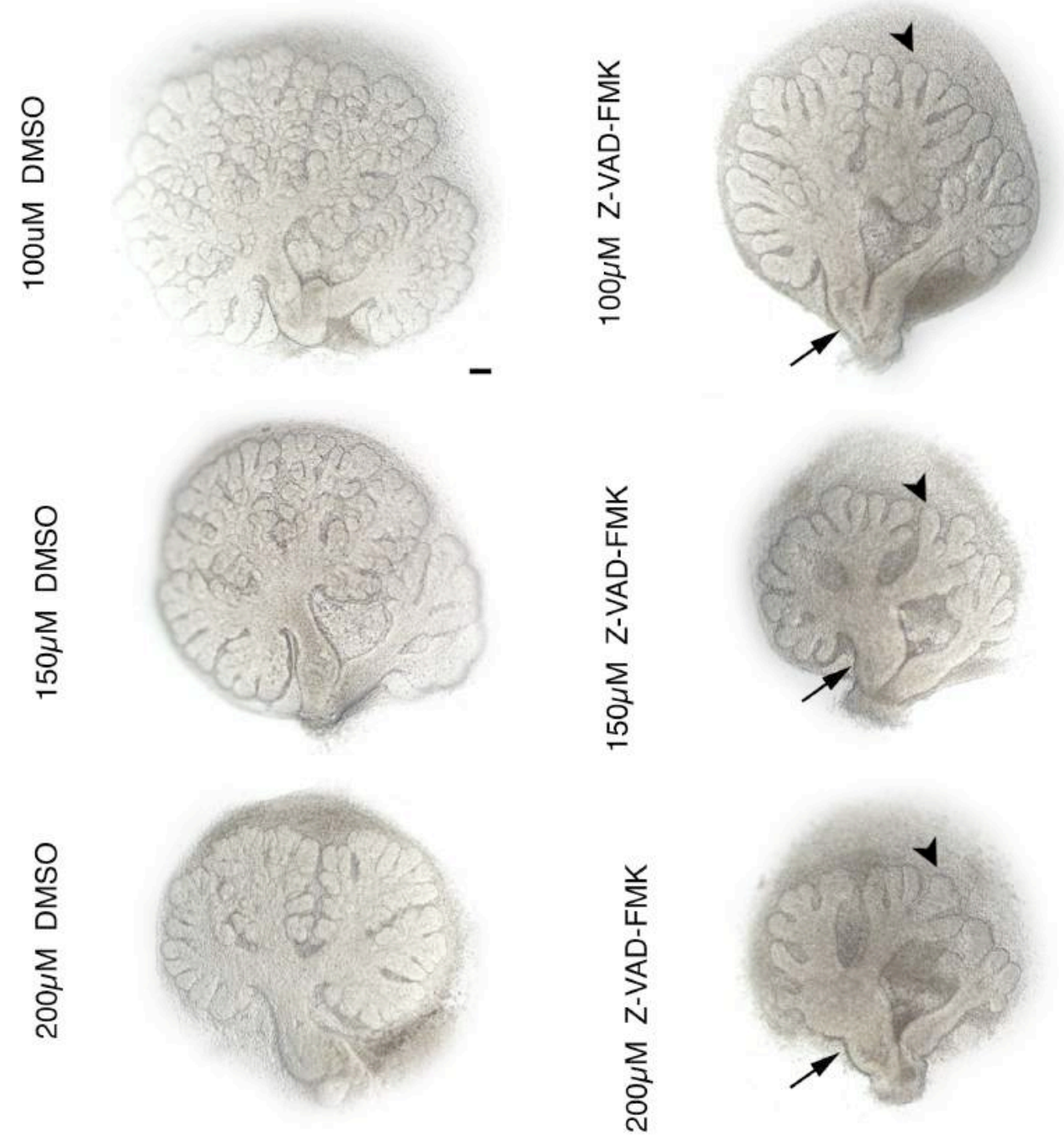

B

$E 13.5+72 h$

C $\quad \mathrm{E} 13.5+72 \mathrm{~h}$ a $150 \mu \mathrm{M}$

D $\quad E 13.5+48 h$
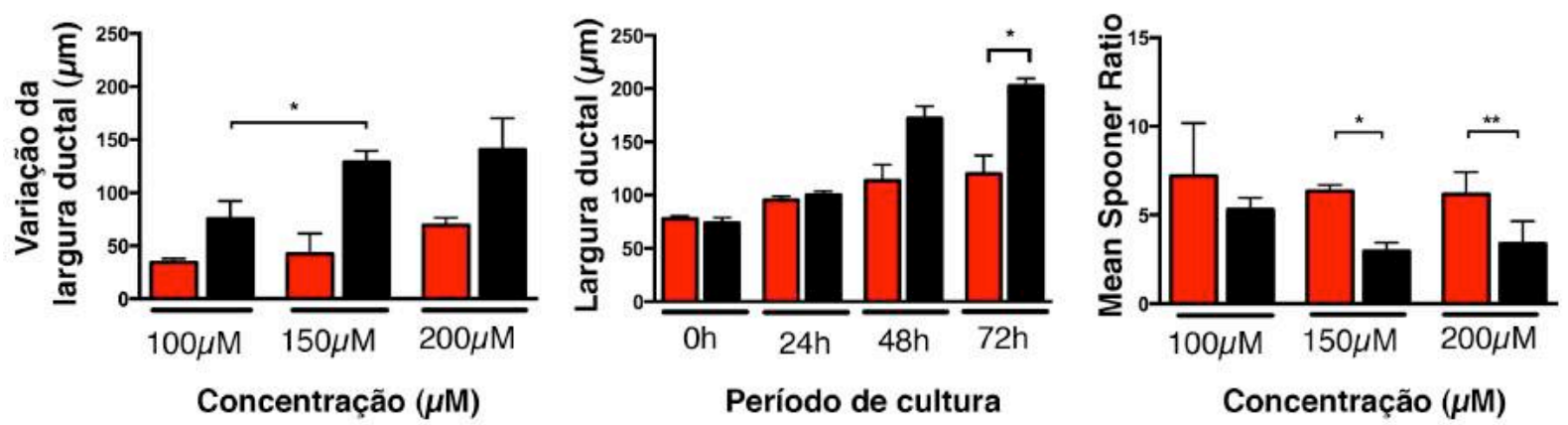

$\square$ Grupo controle (DMSO)

Grupo experimental (Z-VAD-FMK) 
Figura 5.9 - Efeitos da inibição de caspases em glândulas salivares de camundongo em estágio pseudoglandular (E13.5). (A) Glândulas salivares em estágio pseudogladular (E13.5) foram cultivadas por $72 \mathrm{~h}$ com DMSO (grupo controle) e pan-inibidor de caspases Z-

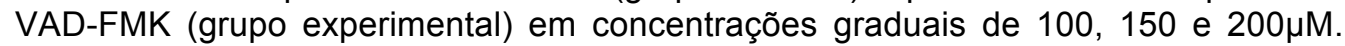
Espécimes tratados com o inibidor (coluna à direita) exibiram ductos mais amplos (setas) e severo retardo e malformação da ramificação acinar (pontas de seta), com fenótipo mais acentuado em culturas de concentração mais elevada. Escala $=100 \mu \mathrm{m}$. (B) Comparação da variação da largura do ducto submandibular de acordo com a concentração de DMSO e Z-VAD-FMK através de teste $t$ não-pareado paramétrico. Após $72 \mathrm{~h}$ de cultivo, a diferença entre a largura final e inicial do ducto submandibular dos grupos controle e experimental foi mensurada, revelando significativo aumento em concentrações mais elevadas de inibidor em relação ao controle $\left(N=9,{ }^{*} p=0.05\right)$. (C) Análise estatística pareada da largura do ducto submandibular dos grupos controle e experimental a cada $24 \mathrm{~h}$ a uma dose de $150 \mu \mathrm{M}$. Após $48 \mathrm{~h}$ é possível observar uma considerável ampliação dos ductos do grupo experimental comparada ao controle, sendo estatisticamente significativo após $72 \mathrm{~h}\left(\mathrm{~N}=9\right.$; $\left.{ }^{*} \mathrm{p}=0.03\right)$. (D) Efeitos da inibição apoptótica na ramificação acinar das glândulas submandibulares através da análise da razão da largura final do ducto (72h) pela inicial (0h) entre grupos controle e experimental (Mean Spooner Ratio). Teste $t$ pareado resultou em importante redução do número de botões nos grupos experimentais de 150 e $200 \mu \mathrm{M}$ de inibidor $\left(\mathrm{N}=9 ;{ }^{*} \mathrm{p}=0.01,{ }^{* *} \mathrm{p}=0.006\right)$. 

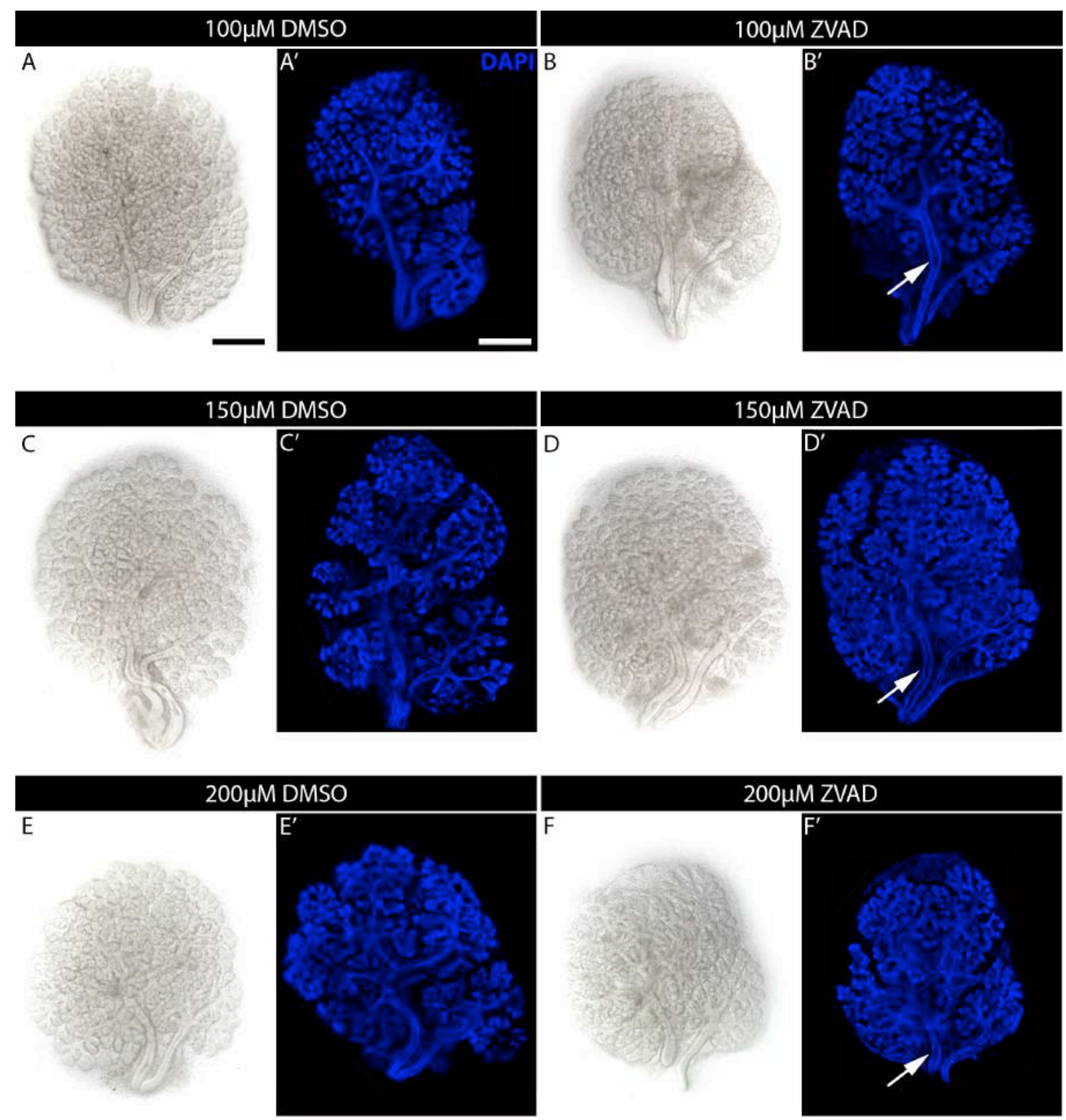

Figura 5.10 - Inibição apoptótica em glândulas salivares de camundongo em estágio canalicular (E14.5). (A-F) Culturas de glândulas salivares em estágio E14.5 após 48h na presença de DMSO (A, C, E) ou Z-VAD-FMK (B, D, F) em diferentes concentrações. (A'-F') Respectivas imagens das culturas glandulares exibindo coloração com marcador morfológico DAPI, em que se observa a formação normal dos espaços luminais mesmo na presença do inibidor apoptótico Z-VAD-FMK (setas). Escala = $500 \mu \mathrm{m}$. 
Os resultados obtidos com a inibição apoptótica durante o desenvolvimento in vitro de glândulas salivares de camundongo revelaram-se dose-dependente em cada grupo analisado, revelando um fenótipo mais acentuado na presença de maiores concentrações de Z-VAD-FMK e do veículo controle DMSO. Para confirmar essa correlação entre dose e nível de inibição apoptótica promovida pelo paninibidor de caspases, investigou-se a localização do inibidor apoptótico e a expressão do marcador de proteína específico de atividade apoptótica - caspase-3 clivada (Figura 5.11 e 5.12). Após as $72 \mathrm{~h}$ de cultivo, o pan-inibidor de caspases acoplado ao marcador fluoresceína (FITC-Z-VAD-FMK) foi adicionado às culturas de glândula salivar em E13.5 (N=9), inibindo e marcando as células em apoptose e também exibindo a localização morfológica de células que foram inibidas anteriormente durante a cultura. Nenhuma marcação por fluoresceína foi detectada as glândulas salivares do grupo controle, exibindo baixos níveis apoptóticos nesse estágio (Figuras 5.11A', 5.11C', 5.11E'). Poucas células positivas foram observadas no mesênquima proporcionalmente à dose de DMSO, evidenciando novamente a citotoxicidade de DMSO em altas concentrações. Em contraste, diversas células marcadas por FITC foram detectadas nas culturas tratadas com o inibidor, particularmente alinhadas somente na região central dos ductos glandulares (Figuras 5.11B', 5.11D', 5.11F'). Consequentemente é possível notar o efeito da inibição apoptótica na formação do espaço luminal, em que ductos glandulares nos grupos controles exibem uma abertura luminal mais evidente em comparação com o

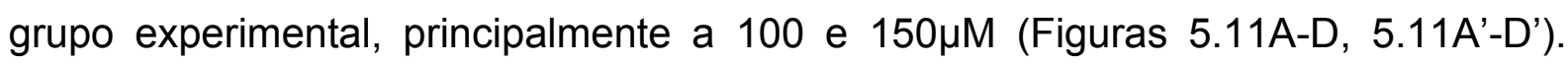
Colorações em HE também foram realizadas em ambos os grupos após a cultura, exibindo ductos sólidos após a inibição apoptótica (Figuras 5.11G, 5.11G').

Além do uso de HE e do marcador FITC-Z-VAD-FMK, a expressão de caspase-3 clivada foi avaliada por imunofluorescência nos grupos controle e experimental (Figura 5.12). A detecção foi observada após $20 \mathrm{~h}$ de cultivo a fim de não se perder o período de maior atividade apoptótica na região dos ductos, visto que a partir de $48 \mathrm{~h}$ as glândulas cultivadas in vitro já estariam na correspondente fase de canalização e com escassa apoptose celular. Dessa maneira também foi possível confirmar a dose-dependência do uso do pan-inibidor de caspases, uma vez que a expressão de caspase-3 clivada foi totalmente negativa nos ductos submandibulares dos grupos experimentais tratados com 150 e $200 \mu \mathrm{M}$ de inibidor (Figuras 5.12B', C'). Poucas células positivas ainda puderam ser detectadas no 
centro do ducto glandular a $100 \mu \mathrm{M}$ (Figura 5.12A', seta), demonstrando insuficiente inibição apoptótica nessa concentração. Todos os grupos controle tratados com DMSO exibiram caspase-3 clivada em células centrais dos ductos submandibulares (Figuras 5.12A-5.12C, setas).
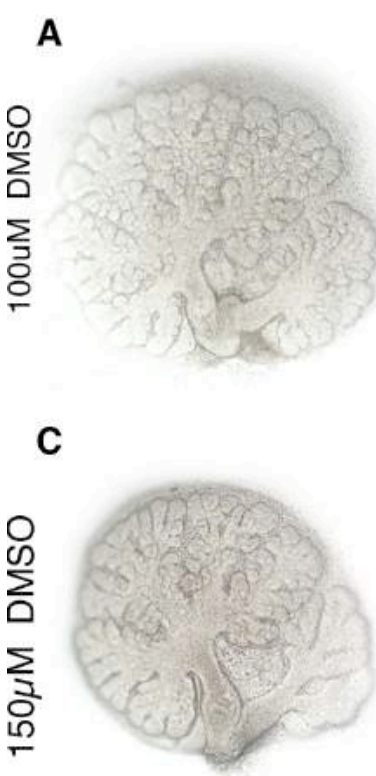

E

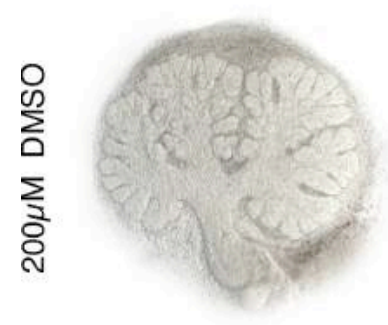

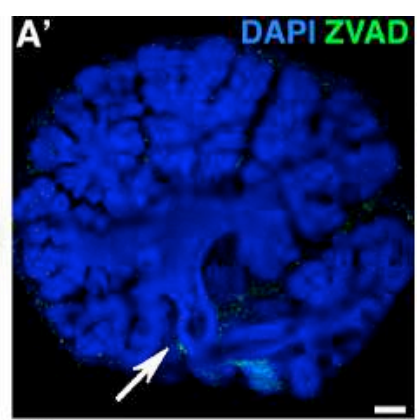
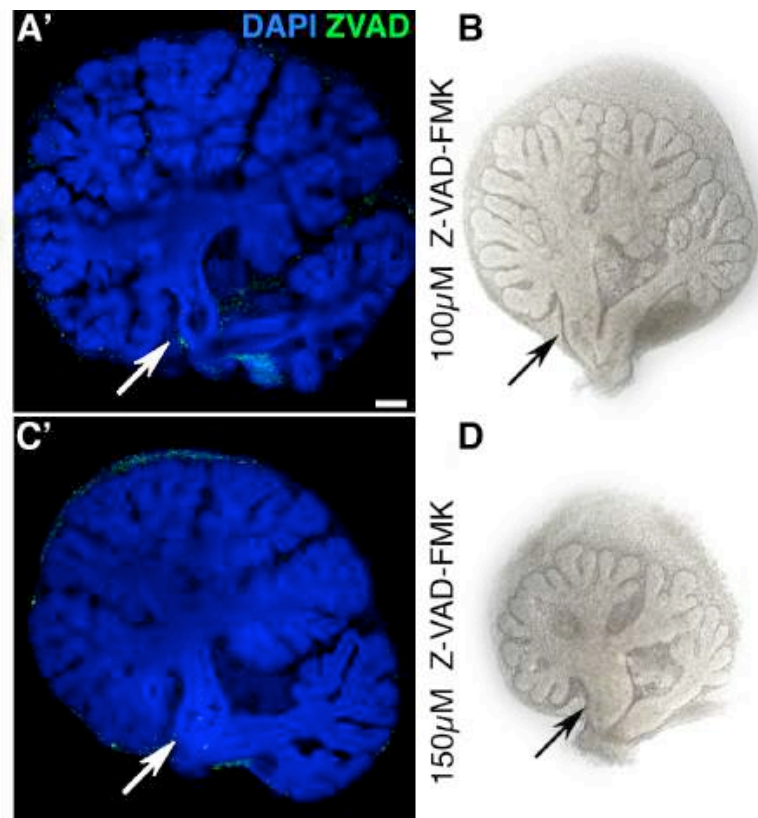

D
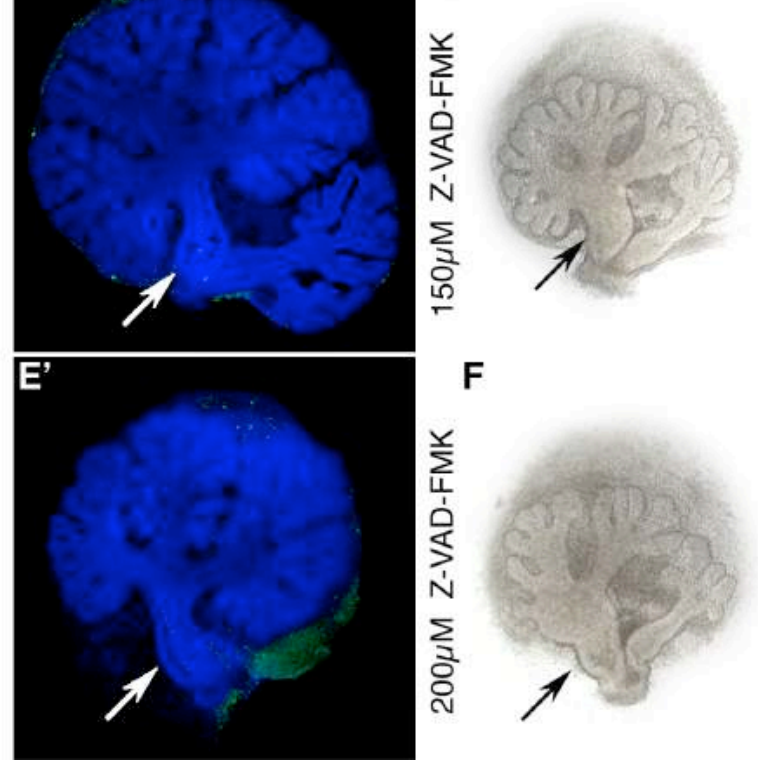

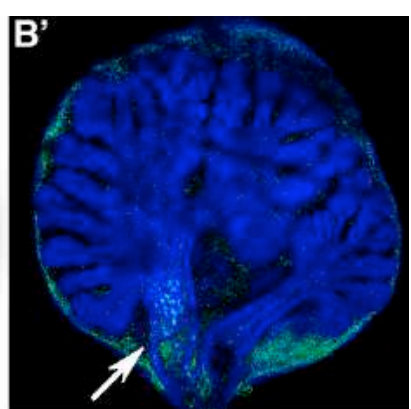

$\overline{\mathbf{D}^{\prime}}$
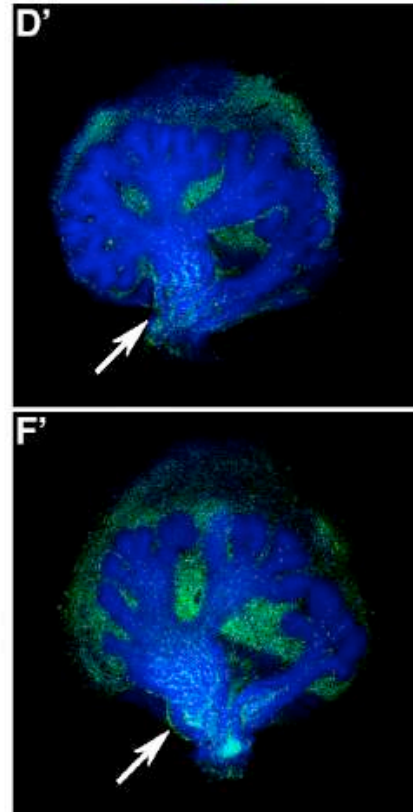

Figura 5.11 - Localização morfológica de células com atividade apoptótica inibida durante o desenvolvimento de glândulas salivares em estágio pseudoglandular. (A-F) Imagens morfológicas das culturas in vitro de glândulas salivares em estágio pseudoglandular E13.5 após $72 \mathrm{~h}$ na presença de DMSO (A, C, E) ou de Z-VADFMK (B, D, F) em diferentes concentrações. ( $\left.A^{\prime}-F^{\prime}\right)$ Visualização do marcador FITC ligado ao pan-inibidor de caspases em glândulas salivares do grupo controle ( $A^{\prime}, C^{\prime}$, E') e experimental (B', D', F'). Ductos excretores principais exibiram estrutura sólida preenchida com células que apresentaram o processo apoptótico interrompido ( $B$ ', D'. F', setas). Células mesenquimais apoptóticas também podem ser observadas em altas concentrações de DMSO e Z-VAD-FMK (E, D', F'). Escala $=500 \mu \mathrm{m}$. 


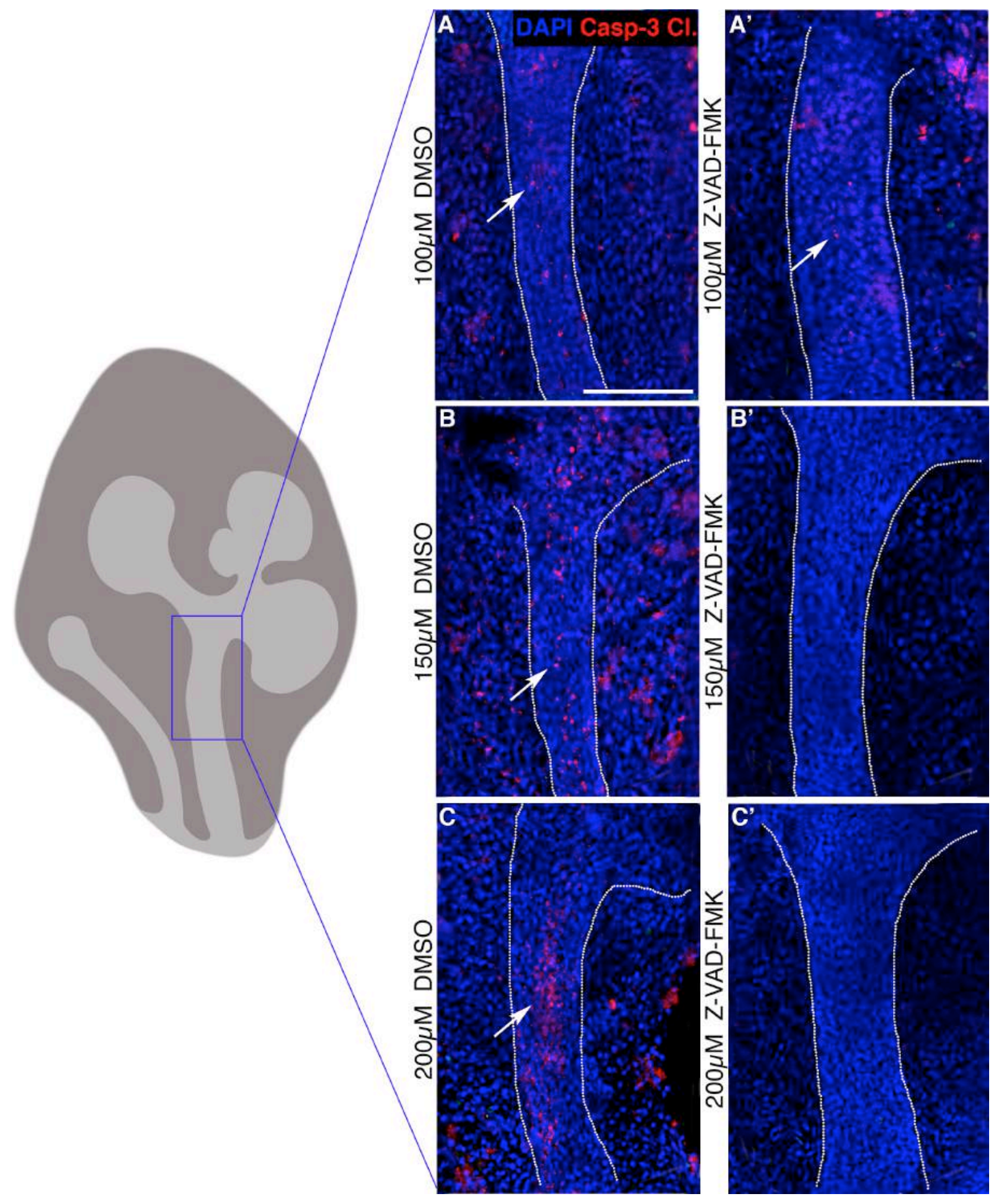

Figura 5.12 - Expressão de caspase-3 clivada em ductos submandibulares de glândulas salivares em estágio pseudoglandular E13.5 após 20h de cultura in vitro. (A, B, C) Ductos de glândula submandibular tratados somente com veículo DMSO em concentrações

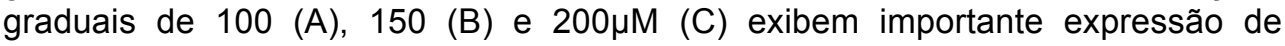
caspase-3 clivada em diversas células localizadas na região central. (A', B', C') Glândulas salivares tratadas com doses correspondentes de pan-inibidor de caspases Z-VAD-FMK em relação ao grupo controle. Ducto submandibular expressa caspase-3 clivada em poucas células na região central $\left(A^{\prime}\right)$, enquanto altas concentrações de Z-VAD-FMK inibiram completamente a atividade apoptótica durante o desenvolvimento glandular (B', C'). N=9. Escala $=100 \mu \mathrm{m}$. 


\section{DISCUSSÃo}

A correta regulação da morte celular programada é essencial para a homeostase dos processos de desenvolvimento e apropriada morfogênese de tecidos embrionários (Flusberg; Sorger, 2015). Evidências relatam atividade apoptótica durante a abertura luminal de ductos das glândulas salivares, caracterizando o processo de cavitação dos cordões epiteliais embriogênicos em fases precoces (Melnick; Jaskoll, 2000; Teshima et al., 2015; Tucker, 2007; Wells; Patel, 2010). Apesar disso, ainda existem dúvidas sobre a ocorrência da apoptose ser um requisito para a abertura luminal, sendo recentemente debatido na literatura em modelos in vivo (Nedvetsky et al., 2014). Em humanos, o padrão de desenvolvimento glandular foi descrito de forma semelhante ao observado em camundongos (Lourenço et al., 2008; Teshima et al., 2011), porém pouco se sabe sobre o papel da apoptose durante a morfogênese glandular humana. A expressão de diversas proteínas apoptóticas analisadas nesse estudo em ambos os modelos animal e humano corrobora com as evidências anteriores, sugerindo a existência de função apoptótica na abertura do espaço luminal glandular.

A atividade de proteínas da família $\mathrm{Bcl}-2$ é extensamente correlacionada com o desencadeamento da cascata apoptótica intrínseca, e o equilíbrio entre membros anti e pró-apoptóticos determinam a viabilidade celular (Moldoveanu et al., 2014). A completa ausência de ambas as principais proteínas pró-apoptóticas Bax e Bak em modelos transgênicos de camundongo resulta em letalidade perinatal ou defeitos severos em diversos tecidos após o nascimento (Lindsten et al., 2000), evidenciando sua importância para a embriogênese. Alternativamente, estudos com a deleção única apenas do gene Bax observaram a presença de glândulas normais com ductos bem formados, porém possivelmente Bak foi capaz de compensar a ausência de Bax e resultar em fenótipo normal (Nedvetsky et al., 2014).

Devido à existência de mecanismos de compensação entre moléculas de função semelhante, é controverso alegar sobre o papel da apoptose a partir de deleções genéticas singulares. A ausência dos fatores antiapoptótico Bcl-2 por sua vez causa imunodeficiência e alterações no desenvolvimento renal, enquanto extensa ativação da apoptose foi observada em fígado e sistema hematopoiético em camundongos 
que não expressam Bcl-xL (Motoyama et al., 1995; Hakem et al., 1998). Corroborando a hipótese de que a apoptose faz parte de um dos mecanismos que regulam o desenvolvimento glandular, nossos resultados ilustraram a expressão das proteínas Bax, Bak, Bcl-x e Bcl-xL em glândulas salivares humanas, particularmente em células ductais com padrão nuclear e citoplasmático. Apesar da maioria dos eventos apoptóticos ocorrerem no citosol, a expressão nuclear de diversos marcadores já foi relatada em células embrionárias de camundongos e células tumorais, majoritariamente associados com apoptose ativa. Estudos com imunoistoquímica e microscopia eletrônica revelaram expressão nuclear proeminente de Bax em adenocarcinoma de colo humano, que se eleva com a estimulação apoptótica após um curto período de tempo (Gajkowska et al., 2001). Achados semelhantes foram encontrados em outras células tumorais (Wang et al., 1999), em que Bax e Bcl-2 foram detectadas em associação com a matriz nuclear. A translocação de Bax para o envelope nuclear também foi detectada em células mamárias de camundongo, cuja expressão nuclear e mitocondrial foi mais elevada após estímulo apoptótico com TGF-beta1 (Motyl et al., 2000). A localização nuclear dessas proteínas em correlação com sua atividade apoptótica confirma nossos resultados, em que a expressão nuclear proeminente de Bax, Bak e Bcl-xL foi encontrada somente em futuras áreas ductais, sugerindo a existência de regulação apoptótica para a abertura luminal das glândulas salivares. Dessa maneira, a atividade pró-apoptótica na formação do espaço luminal parece ser majoritariamente controlada por Bak, uma vez que sua localização nuclear foi mais pronunciada comparada com a de Bax. Por outro lado, a modulação da apoptose durante a abertura inicial é potencialmente controlada por $\mathrm{Bcl}-\mathrm{xL}$, enquanto fases posteriores expressaram mais Bcl-x.

As proteínas pró-apoptóticas Bad e Bid apresentam um importante papel na indução apoptótica a partir de ativação extrínseca, transmitindo o sinal de morte celular através de caspase-8 (Li et al., 1998; Luo et al., 1998). A ausência de ambos os reguladores em nossa análise sugere que a ativação apoptótica no desenvolvimento glandular humano depende apenas da sinalização intrínseca, confirmada também pela expressão proeminente de Bax e Bak em todos os estágios morfogenéticos. A deficiência de Bid em modelos in vivo resultou em resistência à apoptose hepatocelular induzida pela via Fas (ligante extrínseco), porém sob 
estimulação intrínseca não se observou alterações de normalidade, sugerindo o requerimento de Bid apenas por estímulo extracelular (Yin et al., 1999). Analogamente, a ausência dupla de Bax e Bak foi resistente a ambos estímulos intrínseco (como deprivação de fator de crescimento e radiação ultravioleta) e extrínseco (como exposição ao ligante Fas), evidenciando sua importância nas duas vias (Wei et al., 2001). Apesar de serem considerados negativos, Bad e Bid foram expressos em um único espécime de glândula salivar fetal. Como os espécimes são provenientes de abortos espontâneos, é possível que particularmente esse feto tenha sido submetido a alguma condição desconhecida como privação nutricional, que pode ter ativado a via extrínseca de maneira generalizada.

As enzimas denominadas caspases são reguladores apoptóticos essenciais para ambas as vias apoptóticas. Em geral encontram-se em forma inativa e, por vezes, em diferentes compartimentos intracelulares, que implica funções distintas durante a embriogênese a depender do tipo celular (Degterev et al., 2003; Ramuz et al., 2003). Relata-se que a expressão nuclear de caspase-7 tem indica atividade apoptótica durante o desenvolvimento dentário e a osteogênese da mandíbula (Leist; Jäättelä, 2001; Matalova et al., 2012; Matalova et al., 2012; Miura, 2012; Svandova et al., 2014). Similarmente, nossos resultados exibiram uma prevalente expressão nuclear de caspase-7 durante a formação ductal, especialmente em proximidade com presuntivas áreas luminais. Além disso, a presença de célula caspase-7 positiva foi observada em núcleo condensado caracteristicamente apoptótico na área central dos lúmens, sugerindo atividade apoptótica nessas regiões. A caspase-7 representa um dos membros executores da cascata apoptótica, e considera-se que divide propriedades semelhantes às de caspase-3. Modelos in vivo com deleção dupla de caspase-3 e -7 demonstram comprometimento da morfogênese, enquanto a presença de caspase-7 é capaz de compensar a ausência de caspase-3 (Lakhani et al., 2006). Estudo em animais transgênicos deficientes em caspase-3 relata que os componentes da via apoptótica atuam somente em tecidos/células específicos e de acordo com o estímulo recebido (Woo et al., 1998). A detecção de caspase-3 é atualmente um dos marcadores de atividade apoptótica mais importantes e aceitos na literatura, porém outras vias de morte celular independentes de caspases tem sido relatadas (Leist; Jäättelä, 2001). Nossos resultados sugerem que a identificação de somente caspase-3 clivada talvez não represente o marcador mais apurado para 
visualizar a presença de apoptose ativa. A ausência de expressão de caspase-3 clivada nos espécimes glandulares humanos analisados indica portanto que caspase-7 pode ser a principal caspase efetora no desenvolvimento das glândulas salivares humanas em contraste com modelos animais já descritos (Jaskoll et al., 2001; Teshima et al., 2015).

Diferente das caspases-3 e -7, caspase-9 é um regulador apical que compõe o complexo apoptossomo juntamente com Apaf-1 e citocromo c, representando portanto um importante receptor apoptótico intrínseco (Riedl; Salvensen, 2007). O requerimento de caspases e Apaf-1 para a embriogênese foi previamente demonstrado através da ocorrência de defeitos de desenvolvimento neural e olfatório correlacionados a funções apoptóticas e não-apoptóticas em modelos de deleção transgênica (Ohsawa et al., 2010). A ausência da enzima iniciadora caspase-9 resultou em efeitos in vivo análogos porém mais severos do que na inexistência de caspase-3 efetora em desenvolvimento cerebral (Hakem et al., 1998; Kuida et al., 1998). Além disso, linhagens de camundongos na supressão de citocromo c também exibiram letalidade em fases embrionárias e maior sensibilidade a sinais intrínsecos e extrínsecos (Li et al., 2000).

A localização intracelular de caspase-9 foi descrita anteriormente em células mamárias, que sugere haver especificidade epitelial dessa proteína e ilustrou uma associação da expressão nuclear de caspase- 9 com a ativação intrínseca apoptótica (Ritter et al., 2000). Outros estudos em cultura de células mamárias relataram a translocação de caspase-9 sob indução apoptótica por estresse celular, que implica a desorganização da barreira núcleo-citoplasma e assim permite a funcionalidade de caspase-3. A ativação de caspase-9 foi essencial para a entrada de caspase-3 no núcleo, ao passo que a translocação nuclear de caspase-9 não demandou a ativação de caspase-3 (Faleiro; Lazebnik, 2000). Tais achados em glândulas mamárias fundamentam os resultados da expressão de caspases-3 e 9 nos espécimes analisados, principalmente por conta da translocação nuclear de caspase-9 ser independente da ativação de caspase-3. 
Em conjunto com caspase-9 na formação do complexo apoptossomo, demonstrou-se a redistribuição de Apaf-1 para o compartimento nuclear durante a indução intrínseca de apoptose em fibroblastos. Em contraste, citocromo c foi encontrado difusamente na porção citoplasmática (Ruiz-Vela et al., 2002). Nas glândulas salivares humanas, resultados semelhantes corroboram esse estudo, ilustrando semelhante localização intracelular dos membros do apoptossomo, o que sugere representar marcadores precoces de ativação do processo de morte celular.

Além da importante atuação apoptótica, a existência de funções adicionais das caspases tem sido sugerida por diversos autores, que inclui a proliferação compensatória de células adjacentes, determinação da viabilidade celular, manutenção de células-tronco, regeneração tecidual e reorganização do citoesqueleto, participação na resposta imune e promoção de diferentes tipos de morte celular programada (Abraham; Shaham, 2004; Kuranaga, 2011). Dessa maneira, a expressão citoplasmática proeminente de caspases-6, -7 e -9 observada nas glândulas salivares humanas em desenvolvimento pode indicar a existência de prováveis funções não-apoptóticas das caspases em determinados estágios de desenvolvimento.

A modulação da atividade apoptótica pode também ser controlada por diversos inibidores endógenos de caspases que compõem a família de proteínas inibidoras de apoptose (IAP) e sugere-se que survivina tenha um importante papel no bloqueio apoptótico durante o desenvolvimento de glândulas salivares. Relata-se importante expressão genética e proteica de survivina durante a formação embrionária ductal e proacinar (Jaskoll et al., 2001). Os níveis de transcrição genética de survivina foram mais elevados na fase final de botão terminal, com significativa diferença estatística em comparação com as fases anteriores. Morfologicamente, a expressão proteica de survivina também foi observada em todas as fases de desenvolvimento glandular, porém com diferente localização intracelular. Durante as fases iniciais de formação ductal, survivina foi predominantemente citoplasmática por todo o epitélio em ramificação, ao passo que a positividade nuclear prevaleceu nas fases finais nas regiões ductais adjacentes ao espaço luminal. Isso sugere que a survivina nuclear tenha um papel de sobrevida fundamental para as células ductais em formação, corroborando com os nossos achados em glândulas humanas. 
Outro estudo em culturas de célula de glândulas salivares humanas também investigou a presença de survivina, exibindo maior expressividade em células glandulares indiferenciadas em comparação com tecidos adultos como relatado previamente. Em contraste com a análise em tecido glandular, a expressão de survivina nos cultivos celulares foi elevada desde os primeiros dias de cultura, sendo marcadamente mais expressa em estruturas acinares formadas. Além disso, a expressão proteica de survivina foi também nuclear e citoplasmática dependendo do estágio de formação acinar, retendo maior positividade citoplasmática em ácinos íntegros (Szlávik et al., 2008). Tais achados sugerem que a survivina seja importante para a sobrevida de células glandulares humanas indiferenciadas, contribuindo para a formação acinar. Em geral, a survivina parece participar ativamente durante o desenvolvimento das glândulas salivares, reforçando as evidências encontradas em nosso estudo.

A análise da presença de marcadores apoptóticos durante as fases morfogenéticas das glândulas salivares humanas fortemente sugeriu a existência de uma importante função apoptótica para a formação luminal, corroborando com estudos anteriores em modelo animal (Cutler; Mooradian, 1987; Melnick; Jaskoll, 2000; Jaskoll et al., 2001; Tucker, 2007). Considerando o exposto, buscou-se então investigar mais especificamente a atuação do mecanismo apoptótico na abertura dos ductos glandulares particularmente através da análise temporal da atividade apoptótica em fases iniciais de desenvolvimento e de abordagens funcionais em culturas de tecido.

A presença de células em ativa apoptose foi inicialmente caracterizada nas fases antecedentes à formação dos lúmens, cuja ocorrência é reportada na literatura somente a partir da fase E14.5 em camundongos pela visualização de células positivas para caspase-3 clivada na glândula submandibular (Jaskoll; Melnick, 1999; Melnick et al., 2001). Nossos achados, no entanto, demonstraram uma expressão mais precoce de células apoptóticas na formação inicial dos ductos glandulares, divergindo dos relatos prévios. A partir do estágio E12.5, já foi possível detectar células TUNEL, Lysotracker e caspase-3 clivada positivas, especificamente na região central dos cordões epiteliais em desenvolvimento, indicando um papel precoce da apoptose nesse processo. A expressão de todos esses marcadores de 
morte celular foi ainda mais expressiva na fase seguinte $E 13.5$, ao passo que tornou-se escassa ou ausente a partir da fase canalicular E14.5. Essa correlação do perfil de expressão apoptótico precoce em glândulas salivares embrionárias nas regiões presuntivas de lúmen ductal foi confirmada com a presença de $\mathrm{K} 7$ no centro das mesmas áreas epiteliais sólidas durante as respectivas fases morfogenéticas E12.5 e E13.5. K7 foi previamente reportado como um potencial marcador para futuras estruturas ductais (Walker et al., 2008), e em nossos resultados também foi bem expressivo em porções luminais de ductos maduros e epitélio oral na fase canalicular. A discrepância de expressão temporal dos marcadores apoptóticos observada em nossos resultados em relação à literatura pode ser devido ao fato de estágios precoces de formação glandular terem sido pouco abordados até o presente ou pelo uso de diferentes abordagens de detecção apoptótica. Jaskoll e Melnick (1999) relataram a presença de células apoptóticas nos ductos glandulares apenas a partir de E14.5 usando o método Apostain, que detecta o DNA após a clivagem por caspases e antes da fragmentação nuclear (Jaskoll; Melnick, 1999). A comparação entre os métodos Apostain e TUNEL demonstrou confiabilidade de ambas as técnicas, porém os resultados exibiram discretas variações temporais e quantitativas (Prochazkova et al., 2003).

Os experimentos funcionais em culturas de glândulas salivares foram realizados para avaliar o efeito da supressão de atividade apoptótica durante o desenvolvimento das glândulas salivares através da pan-inibição de caspases. $O$ inibidor Z-VAD-FMK vincula-se irreversivelmente a caspases ativas e bloqueia a transmissão do sinal de morte celular. Mesmo em concentrações mais baixas a $100 \mu \mathrm{M}$ já foi possível comprometer o desenvolvimento glandular em estágios iniciais nas culturas a partir de E12.5 e E13.5. Similarmente, estudos prévios em culturas celulares epiteliais demonstraram que a inibição apoptótica foi suficiente para prevenir a formação luminal (Martín-Belmonte et al., 2008), porém essa inibição só provocou o retardo da abertura luminal em modelos epiteliais de próstata ao estimular-se a polarização celular (Pearson et al., 2009). Estudos em culturas de células mamárias relataram resultados semelhantes ao inibir a apoptose, correlacionando-a com a geração e manutenção de espaços luminais (Debnath et al., 2002).

Os defeitos na formação ductal e na ramificação dos botões glandulares 
devido à pan-inibição de caspases revelaram importante função apoptótica durante o desenvolvimento das glândulas salivares. Vale ressaltar que essa inibição pode induzir a atividade de vias apoptóticas alternativas caspase-independentes, como autofagia e necrose, que podem compensar a ausência da apoptose (Vandenabeele et al., 2006), além das caspases serem também correlacionadas com outros processos celulares dinâmicos de desenvolvimento (Wang; Lenardo, 2000; Kuranaga, 2011). Relata-se ainda que a apoptose seja fundamental também para enviar sinais de proliferação, movimento e estruturação a células vizinhas (PerezGarijo; Steller, 2015). Dessa forma, a inibição de todas as caspases nas culturas glandulares potencialmente afetou a apoptose e diversos outros mecanismos embriogênicos associados à morte celular que resultaram em severo fenótipo ductal e acinar.

Estudos que analisaram as interações epiteliais durante o desenvolvimento das glândulas salivares demonstraram uma ligação importante entre o controle da formação luminal e da polarização celular (Cutler; Mooradian, 1987; Andrew; Ewald, 2010), confirmados por investigações genéticas mais recentes (Nedvetsky et al., 2014). O peptídeo instestinal vasoativo (VIP) foi relatado como um importante regulador de estágios críticos na tubulogênese epitelial em desenvolvimento glandular, em que a adição de VIP exógeno em culturas foi capaz de estimular a formação de um espaço luminal contíguo, identificado pela marcação apical de aPKC e subapical de GM130 a partir de E13. Além disso, sugere-se que a formação do espaço luminal não demanda a atividade apoptótica, uma vez que observou-se a formação normal dos lúmens em glândulas salivares cultivadas com o pan-inibidor de caspases (Nedvetsky et al., 2014). Nesses experimentos, contudo, a concentração de inibidor utilizada foi de apensa $50 \mu \mathrm{M}$, enquanto os resultados desse estudo demonstraram apenas inibição discreta e parcial da formação das

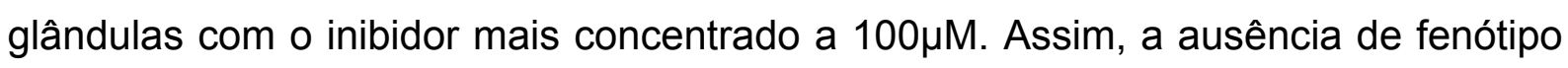
observada foi possivelmente ocasionada pelo uso de quantidade insuficiente de inibidor. Nesse mesmo estudo, a formação normal de lúmens também foi observada em camundongos transgênicos com a deleção de Bax, um importante fator próapoptótico, porém os efeitos da deleção nas glândulas salivares foram observados somente no estágio E17. Nesse modelo in vivo, é possível que a formação luminal dependente de Bax tenha sido compensada por outro mecanismo de morte celular 
ou por moléculas de função análoga a Bax. Essa proteína é requerida apenas para a apoptose intrínseca e divide funções pró-apoptóticas similares a Bak, sendo inerentemente compensada na sua ausência (Lindsten et al., 2000; Karbowski et al., 2006). As vias apoptóticas são estritamente reguladas por um complexo mecanismo de inúmeras sinalizações moleculares, uma vez que representam um fundamental mecanismo embriogênico, homeostásico e patológico. Portanto, a compensação dessas vias é um processo comumente encontrado em outros tecidos, como já observada durante a formação de membros (Miura, 2012; Suzanne; Steller, 2013), particularmente dificultando a interpretação dos modelos in vivo.

Recentemente, um outro mecanismo celular chamado anoikis tem sido indicado como um importante processo para a tubulogênese, como demonstrado durante o desenvolvimento de glândulas mamárias (Debnath et al., 2002; Mailleux et al., 2007). Esse processo é baseado na perda de ancoragem da célula que perturba as interações de adesão célula-célula e célula-matriz extracelular, possuindo uma função importante na indução fisiológica da apoptose durante desenvolvimento e patogênese, principalmente em relação à transformação metastática (Grossmann, 2002). Corroborando essa hipótese, os resultados observados nas culturas glandulares, o marcador FITC do pan-inibidor de caspases identificou a presença de diversas células desorganizadas que permaneceram no centro do presuntivo espaço ductal, não exibindo um lúmen propriamente formado e apresentando-se destacadas da camada epitelial polarizada que contorna a cavidade. Dessa maneira, considerando que esse processo também é potencialmente responsável pela indução da apoptose, o mecanismo de cavitação pode na verdade representar um caso especial de esvaziamento de cordão epitelial, que requere a polarização das células e um passo adicional de desobstrução do lúmen tipicamente promovida por morte celular programada (Andrew; Ewald, 2010).

De maneira conjunta, os dados obtidos com os modelos humano e animal desse estudo sugerem que a formação do espaço luminal dos ductos das glândulas salivares tem importante contribuição do mecanismo apoptótico nos estágios precoces. A redução da expressividade de células apoptóticas durante o desenvolvimento glandular em ambos os ductos e ácinos indica que a formação e manutenção do espaço luminal das estruturas subsequentes ocorram possivelmente através de outros mecanismos. Processos como "anoikis", polarização celular e vias 
de morte celular programada não-apoptóticas podem ser essenciais para o desenvolvimento das estruturas tardias, sendo interessante explorar esses mecanismos posteriormente para estabelecer uma causa definitiva entre morte celular e formação e manutenção do espaço luminal. 


\section{CONCLUSÕES}

Os dados obtidos nesse trabalho evidenciaram em geral um padrão positivo de expressão de diversos reguladores apoptóticos durante a morfogênese de glândulas salivares humanas, indicando a participação ativa dessas proteínas durante o desenvolvimento glandular. Além disso, correlacionou-se temporal e morfologicamente a presença dos principais marcadores específicos para a atividade de apoptose em respectivo modelo animal, e a inibição apoptótica funcional das culturas glandulares resultou em um fenótipo importante na formação do lúmen ductal. Sucintamente, os dados ilustrados respondem às principais questões deste trabalho da seguinte maneira:

- A via apoptótica do tipo intrínseca parece ser de fato a responsável pela abertura luminal das glândulas salivares humanas, visto que reguladores positivos da via extrínseca Bad e Bid foram totalmente ausentes;

- A expressão da maioria das proteínas pró-apoptóticas concentrou-se nas fases pseudoglandular e canalicular das glândulas humanas fetais;

- A expressão nuclear de diversas proteínas durante o desenvolvimento glandular humano parece estar associado com a função apoptótica ativa das células epiteliais;

- Dentre as caspases efetoras, a expressão de caspase-7 sugere ser a mais envolvida no desenvolvimento glandular humano;

- A apoptose está presente em fases precoces de desenvolvimento glandular, previamente ao que se relata na literatura (canalicular);

- A ausência da ativação apoptótica in vitro ocasiona defeitos de formação dos ductos e prejudica o desenvolvimento normal das glândulas salivares.

Conjuntamente, esses achados corroboram a hipótese de que a apoptose é um importante mecanismo para a tubulogênese das glândulas salivares, e que provavelmente essas moléculas também possuam outras funções não-apoptóticas durante esse processo. Estudos emergentes em biologia de desenvolvimento têm revelado novas abordagens sobre a formação glandular, especialmente com a disponibilidade de mais linhagens transgênicas, trazendo novas perspectivas para o papel apoptótico durante a morfogênese. A busca por tratamentos capazes de 
substituir ou regenerar glândulas salivares ausentes ou prejudicadas por doenças ou tratamentos radioterápicos ainda representa uma importante luta para reconstituir a função glandular tão importante para a saúde da cavidade oral. Assim, a melhor compreensão o controle dos processos biológicos específicos durante a formação das glândulas salivares potencialmente contribui com a identificação de novas vias de sinalização e moléculas-alvo, colaborando com o desenvolvimento de terapias regenerativas mais eficazes de disfunções e doenças glandulares. 


\section{REFERÊNCIAS ${ }^{1}$}

Abraham MC, Shaham S. Death without caspases, caspases without death. Trends Cell Biol. 2004 Apr;14(4):184-93.

Altieri DC. Survivin and IAP proteins in cell-death mechanisms. Biochem J. 2010;430(2):199-205.

Amano O, Mizobe K, Bando Y, Sakiyama K. Anatomy and histology of rodent and human major salivary glands: -overview of the Japan salivary gland society. Acta Histochem Cytochem. 2012 Oct;45(5):241-50.

Andrew DJ, Ewald AJ. Morphogenesis of epithelial tubes: Insights into tube formation, elongation, and elaboration. Dev Biol. 2010 May;341(1):34-55.

Andrew DJ, Henderson KD, Seshaiah P. Salivary gland development in Drosophila melanogaster. Mech Dev. 2000 Mar;92(1):5-17.

Arur S, Uche UE, Rezaul K, Fong M, Scranton V, Cowan AE, et al. Annexin I Is an Endogenous Ligand that Mediates Apoptotic Cell Engulfment. Dev Cell. 2003 Apr;4(4):587-98.

Azuma N, Katada Y, Kitano S, Sekiguchi M, Kitano M, Nishioka A, et al. Rapid decrease in salivary epidermal growth factor levels in patients with Sjögren's syndrome: A 3-year follow-up study. Mod Rheumatol. 2015 Nov; 25(6):876-82. doi: 10.3109/14397595.2015.1034941.

Belizário J, Vieira-Cordeiro L, Enns S. Necroptotic cell death signaling and execution pathway: Lessons from Knockout Mice. Mediators Inflamm. 2015;2015:1-15. http://dx.doi.org/10.1155/2015/128076.

Borghese $\mathrm{E}$. The development in vitro of the submandibular and sublingual glands of Mus musculus. J Anat. $1950 \mathrm{Jul} ; 84(3): 287-302$.

Bouwens L. Cytokeratins and cell differentiation in the pancreas. J Pathol. 1998.;184(3):234-9.

\footnotetext{
${ }^{1}$ De acordo com estilo Vancouver.
} 
Ceballos-Cancino G, Espinosa M, Maldonado V, Melendez-Zajgla J. Regulation of mitochondrial Smac/DIABLO-selective release by survivin. Oncogene. 2007 Nov;26(54):7569-75.

Chipuk JE, Moldoveanu T, Llambi F, Parsons MJ, Green DR. The BCL-2 Family Reunion. Mol Cell. 2010 Feb;37(3):299-310. doi: 10.1016/j.molcel.2010.01.025.

Chung S, Andrew DJ. The formation of epithelial tubes. J Cell Sci. 2008;121():35014.

Colas J.-F, Schoenwolf GC. Towards a cellular and molecular understanding of neurulation. Dev Dyn. 2001;221(2):117-45.

Coucouvanis E, Martin GR. Signals for death and survival: A two-step mechanism for cavitation in the vertebrate embryo. Cell. 1995;83(2):279-87.

Crook NE, Clem RJ, Miller LK. An apoptosis-inhibiting baculovirus gene with a zinc finger-like motif. J Virol. 1993;67(4):2168-174.

Cutler $\mathrm{L}$. The role of extracellular matrix in the morphogenesis and differentiation of salivary glands. Adv Dent Res. 1990 Jun;4: 27-33.

Cutler L, Gremski W. Epithelial-mesenchymal interactions in the development of salivary glands. Crit Rev Oral Biol Med. 1991;2(1):1-12.

Cutler L, Mooradian B. Lumen formation during development of the rat submandibular gland. J Dent Res. 1987 Oct;66(10):1559-62.

Danial NN, Korsmeyer SJ. Cell death: Critical control points. Cell. 2004 Jan;116(2):205-19.

Debnath J, Mills KR, Collins NL, Reginato MJ, Muthuswamy SK, Brugge JS. The role of apoptosis in creating and maintaining luminal space within normal and oncogeneexpressing mammary acini. Cell. 2002 Oct;111(1):29-40.

Degterev A, Boyce M, Yuan J. A decade of caspases. Oncogene. 2003 Nov;22(53):8543-67. 
Delli K, Spijkervet FK, Kroese FG, Bootsma H, Vissink A. Xerostomia. Monogr Oral Sci. 2014;24:109-25. doi: 10.1159/000358792.

Denny P, Ball W, Redman R. Salivary glands: a paradigm for diversity of gland development. Crit Rev Oral Biol Med. 1997;8(1):51-75.

Dohi T, Okada K, Xia F, Wilford CE, Samuel T, Welsh K, et al. An IAP-IAP complex inhibits apoptosis. J Biol Chem. 2004 Aug;279(33):34087-90.

Ellis HM, Horvitz HR. Genetic control of programmed cell death in the nematode C. elegans. Cell. 1986;44(6):817-29.

Elmore S. Apoptosis: A review of programmed cell death. Toxicol Pathol., v. 35, n. 4, p. 495-516, 2007.

Fábián TK, Hermann P, Beck A, Fejérdy $P$, Fábián G. Salivary defense proteins: Their network and role in innate and acquired oral immunitylnternational. J Mol Sci. 2012;13:4295-320. doi:10.3390/ijms13044295.

Faleiro L, Lazebnik Y. Caspases disrupt the nuclear-cytoplasmic barrier. J Cell Biol. 2000 Nov;151(5):951-9.

Flusberg DA, Sorger PK. Surviving apoptosis: life-death signaling in single cells. Trends Cell Biol. 2015 Aug;25(8):446-58. doi: 10.1016/j.tcb.2015.03.003.

Gajkowska B, Motyl T, Olszewska-Badarczuk H, Godlewski MM. Expression of BAX in cell nucleus after experimentally induced apoptosis revealed by immunogold and embedment-free electron microscopy. Cell Biol Int. 2001;25(8):725-33.

Gardai S, McPhillips KA, Frasch SC, Janssen WJ, Starefeldt A, Murphy-Ullrich JE, et al. Cell-surface calreticulin initiates clearance of viable or apoptotic cells through trans-activation of LRP on the phagocyte. Cell. 2005 Oct.;123(2):321-34.

Ghabrial AS, Krasnow MA. Social interactions among epithelial cells during tracheal branching morphogenesis. Nature. 2006;441(7094):746-9.

Gresik E. The granular convoluted tubule (GCT) cell of rodent submandibular glands. Microsc Res Tech. 1994;27(1):1-24. 
Grossman D, Kim PJ, Blanc-Brude OP, Brash DE, Tognin S, Marchisio PC, et al. Transgenic expression of survivin in keratinocytes counteracts UVB-induced apoptosis and cooperates with loss of p53. J Clin Invest. 2001 Oct;108(7):991-9.

Grossmann J. Molecular mechanisms of "detachment-induced apoptosis--Anoikis". Apoptosis. 2002;7(3):247-60.

Hakem R, Hakem A, Duncan GS, Henderson JT, Woo M, Soengas MS, et al. Differential requirement for Caspase 9 in apoptotic pathways in vivo. Cell. 1998 Aug;94(3):339-52.

Hengartner MO. The biochemistry of apoptosis. Nature. 2000 Oct;407(6805): 770-6.

Hockenbery D, Nuñez G, Milliman C, Schreiber RD, Korsmeyer SJ. Bcl-2 is an inner mitochondrial membrane protein that blocks programmed cell death. Nature. 1990 Nov;348(6299):334-6.

Hoffman MP, Kidder BL, Steinberg ZL, Lakhani S, Ho S, Kleinman HK, et al. Gene expression profiles of mouse submandibular gland development: FGFR1 regulates branching morphogenesis in vitro through BMP- and FGF-dependent mechanisms. Development. 2002 Dec;129(24):5767-78.

Hsu JC, Yamada KM. Salivary gland branching morphogenesis--recent progress and future opportunities. Int J Oral Sci. 2010 Sep;2(3):117-26.

Humphrey SP, Williamson RT. A review of saliva: Normal composition, flow, and function. J Prosthet Dent. 2011;85(2):162-9.

lanez RF, Buim ME, Coutinho-Camillo CM, Schultz R, Soares FA, Lourenço SV. Human salivary gland morphogenesis: myoepithelial cell maturation assessed by immunohistochemical markers. Histopathology. 2010;57(3):410-17.

Iruela-Arispe ML, Beitel GJ. Tubulogenesis. Development. 2013;140(14): 2851-5.

Jaskoll T, Melnick M. Submandibular gland morphogenesis: stage-specific expression of TGF-alpha/EGF, IGF, TGF-beta, TNF, and IL-6 signal transduction in normal embryonic mice and the phenotypic effects of TGF-beta2, TGF-beta3, and EGF-r null mutations. Anat Rec. 1999 Nov;256(3): 252-68. 
Jaskoll T, Chen H, Min Zhou Y, Wu D, Melnick M. Developmental expression of survivin during embryonic submandibular salivary gland development. BMC Dev Biol. 2001;1:5. doi:10.1186/1471-213X-1-5.

Johnson ME, Howerth EW. Survivin: a bifunctional inhibitor of apoptosis protein. Vet Pathol. 2004 Nov;41(6):599-607.

Junqueira L, Carneiro J. Histologia básica. 10. ed. Rio de Janeiro: Guanabara Koogan; 2004.

Kamei M, Saunders WB, Bayless KJ, Dye L, Davis GE, Weinstein BM. Endothelial tubes assemble from intracellular vacuoles in vivo. Nature. 2006 Jul;442(7101):4536.

Karbowski M, Norris KL, Cleland MM, Jeong SY, Youle RJ. Role of Bax and Bak in mitochondrial morphogenesis. Nature. 2006 Oct;443(7112):658-62.

Katchburian E, Arana V. Histologia e embriologia oral. Rio de Janeiro: Guanabara Koogan; 2004.

Kerman BE, Cheshire AM, Andrew DJ. From fate to function: the Drosophila trachea and salivary gland as models for tubulogenesis. Differentiation. 2006; 74(7):326-48.

Kerr JF, Wyllie AH, Currie AR. Apoptosis: a basic biological phenomenon with wideranging implications in tissue kinetics. Br J Cancer. 1972 Aug;26(4):239-57.

Kuida K, Haydar TF, Kuan CY, Gu Y, Taya C, Karasuyama H, et al. Reduced apoptosis and cytochrome C-mediated caspase activation in mice lacking Caspase 9. Cell. 1998;94(3):325-37.

Kuranaga E. Caspase signaling in animal development. Dev Growth Differ. 2001;53(2):137-48.

Kwon HR, Larsen M. The contribution of specific cell subpopulations to submandibular salivary gland branching morphogenesis. Curr Opin Genet Dev. 2015;32:47-54. 
Lafont E, Milhas D, Teissié J, Therville N, Andrieu-Abadie N, Levade T, Caspase-10dependent cell death in Fas/CD95 signalling is not abrogated by caspase inhibitor zVAD-fmk. PloS one. 2010 Oct;5(10):e13638. doi: 10.1371/journal.pone.0013638.

Lakhani SA, Masud A, Kuida K, Porter GA Jr, Booth CJ, Mehal WZ, et al. Caspases 3 and 7: key mediators of mitochondrial events of apoptosis. Science. 2006;311(5762):847-51.

Leist $M$, Jäättelä M. Four deaths and a funeral: from caspases to alternative mechanisms. Nat Rev Mol Cell Biol. 2001 Aug;2(8):589-98.

Li H, Zhu H, Xu CJ, Yuan J. Cleavage of BID by caspase 8 mediates the mitochondrial damage in the Fas pathway of apoptosis. Cell. 1998 Aug;94(4):491501.

Li K, Li Y, Shelton JM, Richardson JA, Spencer E, Chen ZJ, et al. Cytochrome c deficiency causes embryonic lethality and attenuates stress-induced apoptosis. Cell. 2000;101(4):389-99.

Lindsten T, Ross AJ, King A, Zong WX, Rathmell JC, Shiels HA, et al. The combined functions of proapoptotic Bcl-2 family members bak and bax are essential for normal development of multiple tissues. Mol Cell. 2000 Dec;6(6):1389-99.

Liston P, Roy N, Tamai K, Lefebvre C, Baird S, Cherton-Horvat G, et al. Suppression of apoptosis in mammalian cells by NAIP and a related family of IAP genes. Nature. 1996 Jan;379(6563):349-53.

Lombaert IMA, Knox SM, Hoffman MP. Salivary gland progenitor cell biology provides a rationale for therapeutic salivary gland regeneration. Oral Dis. 2011Jul;17(5):445-9.

Loreto C, Caltabiano R, Musumeci G, Caltabiano C, Greco MG, Leonardi R. Hepatocyte growth factor receptor, c-Met, in human embryo salivary glands. An immunohistochemical study. Anat Histol Embryol. 2010 Jun;39(3):173-7. doi: 10.1111/j.1439-0264.2010.00991.x.

Lourenço SV, Coutinho-Camillo CM, Buim ME, Uyekita SH, Soares FA. Human salivary gland branching morphogenesis: Morphological localization of claudins and its parallel relation with developmental stages revealed by expression of cytoskeleton and secretion markers. Histochem Cell Biol. 2007 Oct;128(4):361-9. 
Lourenço SV, Uyekita SH, Lima DM, Soares FA. Developing human minor salivary glands: Morphological parallel relation between the expression of TGF-beta isoforms and cytoskeletal markers of glandular maturation. Virchows Arch. 2008 Apr;452(4):427-34.

Lourenço SV, Kapas S. Integrin expression in developing human salivary glands. Histochem Cell Biol. 2005;124:391-9.

Lubarsky B, Krasnow MA. Tube morphogenesis. Cell. 2003 Jan;112(1):19-28.

Luo X, Budihardjo I, Zou H, Slaughter C, Wang X. Bid, a Bcl2 interacting protein, mediates cytochrome $c$ release from mitochondria in response to activation of cell surface death receptors. Cell. 1998;94(4):481-90.

Mailleux AA, Overholtzer M, Schmelzle T, Bouillet P, Strasser A, Brugge JS. BIM Regulates Apoptosis during Mammary Ductal Morphogenesis, and Its Absence Reveals Alternative Cell Death Mechanisms. Dev Cell. 2007;12(2): 221-34.

Mandarim-de-Lacerda CA. Foot length growth related to crown-rump length, gestational age and weight in human staged fresh fetuses. An index for anatomical and medical use. Surg Radiol Anat. 1990;12(2):103-7.

Martín-Belmonte F, Yu W, Rodríguez-Fraticelli AE, Ewald AJ, Werb Z, Alonso MA, et al. Cell-polarity dynamics controls the mechanism of lumen formation in epithelial morphogenesis. Curr Biol. 2008;18(7):507-13.

Mata AD, Marques D, Rocha S, Francisco H, Santos C, Mesquita MF, et al. Effects of diabetes mellitus on salivary secretion and its composition in the human. Mol Cell Biochem. 2004;261(1-2):137-42.

Matalova E, Svandova E, Tucker AS. Apoptotic signaling in mouse odontogenesis. Omics. 2012;16(1-2):60-70.

Matalova E, Vanden Berghe T, Svandova E, Vandenabeele P, Healy C, Sharpe PT, et al. Caspase-7 in molar tooth development. Arch Oral Biol. 2012 Nov;57(11):147481.

Matsuo R. Role of saliva in the maintenance of taste sensitivity. Crit Rev Oral Biol Med. 2000;11(2):216-29. 
Mcbride ML, Baillie J, Poland BJ. Growth parameters in normal fetuses. Teratology. 1984;29(2):185-91.

Mcdonnell TJ, Deane N, Platt FM, Nunez G, Jaeger U, McKearn JP, et al. bcl-2immunoglobulin transgenic mice demonstrate extended $B$ cell survival and follicular lymphoproliferation. Cell. 1989;57(1):79-88.

Melnick M, Jaskoll T. Mouse submandibular gland morphogenesis: a paradigm for embryonic signal processing. Crit Rev Oral Biol Med. 2000 Jan;11(2):199-215.

Melnick M, Chen H, Zhou Y, Jaskoll T. Embryonic mouse submandibular salivary gland morphogenesis and the TNF/TNF-R1 signal transduction pathway. Anat Rec. 2001Mar;262(3):318-30.

Metzger RJ, Klein OD, Martin GR, Krasnow MA. The branching programme of mouse lung development. Nature. 2008 Jun;453(7196):745-50. doi: 10.1038/nature07005.

Milunsky JM, Zhao G, Maher TA, Colby R, Everman DB. LADD syndrome is caused by FGF10 mutations. Clin Genet. 2006 Apr;69(4):349-54.

Miura M. Apoptotic and nonapoptotic caspase functions in animal development. Cold Spring Harbor Perspect Biol. 2012 Oct;4(10). pii: a008664. doi: 10.1101/cshperspect.a008664. Review.

Moldoveanu T, Follis AV, Kriwacki RW, Green DR. Many players in BCL-2 family affairs. Trends Biochem Sci. 2014 Mar;39(3):101-11. doi: 10.1016/j.tibs.2013.12.006.

Motoyama N, Wang F, Roth KA, Sawa H, Nakayama K, Nakayama K, et al. Massive cell death of immature hematopoietic cells and neurons in Bcl-x-deficient mice. Science. 1995;267(5203):1506-10.

Motyl T, Gajkowska B, Płoszaj T, Wareski P, Skierski J, Zimowska W, et al. Expression and subcellular redistribution of Bax during TGF-beta1-induced programmed cell death of HC11 mouse mammary epithelial cells. Cell Mol Biol (Noisy-le-grand). 2000 Feb;46(1):175-85.

Nedvetsky PI, Emmerson E, Finley JK, Ettinger A, Cruz-Pacheco N, Prochazka J, et al. Parasympathetic innervation regulates tubulogenesis in the developing salivary gland. Dev Cell. 2014;30(4):449-62. 
Nicholson DW. Caspase structure, proteolytic substrates, and function during apoptotic cell death. Cell Death Differ. 1999;6(11):1028-42.

Nikitakis NG, Sauk JJ, Papanicolaou SI. The role of apoptosis in oral disease: Mechanisms; aberrations in neoplastic, autoimmune, infectious, hematologic, and developmental diseases; and therapeutic opportunities. Oral Surg Oral Med Oral Pathol Oral Radiol Endod. 2004 Apr;97(4):476-90.

Noguchi S, Ohba Y, Oka T. Effect of salivary epidermal growth factor on wound healing of tongue in mice. Am J Physiol. 1991;260:E620-E5.

Ohsawa S, Hamada S, Kuida K, Yoshida H, Igaki T, Miura M. Maturation of the olfactory sensory neurons by Apaf-1/caspase-9-mediated caspase activity. Proc Nat Acad Sci U S A. 2010 Jul;107(30):13366-71.

Patel N, Sharpe PT, Miletich I. Coordination of epithelial branching and salivary gland lumen formation by Wnt and FGF signals. Dev Biol. 2011 Oct; 358(1):156-67.

Patel VN, Rebustini IT, Hoffman MP. Salivary gland branching morphogenesis. Differentiation. 2006 Sp;74(7):349-64.

Pearson JF, Hughes S, Chambers K, Lang SH. Polarized fluid movement and not cell death, creates luminal spaces in adult prostate epithelium. Cell Death Differ. 2009 Mar; 16(3):475-82.

Pedersen AM, Bardow A, Jensen SB, Nauntofte B. Saliva and gastrointestinal functions of taste, mastication, swallowing and digestion. Oral Dis. 2002 May;8(3):117-29.

Perez-Garijo A, Steller H. Spreading the word: non-autonomous effects of apoptosis during development, regeneration and disease. Development. 2015 Oct;142(19):3253-62.

Prochazkova J, Kylarova D, Vranka P, Lichnovsky V. Comparative study of apoptosis-detecting techniques: TUNEL, apostain, and lamin B. BioTechniques. 2003 Sep;35(3):528-34.

Ramuz O, Isnardon D, Devilard E, Charafe-Jauffret E, Hassoun J, Birg F, et al. Constitutive nuclear localization and initial cytoplasmic apoptotic activation of 
endogenous caspase-3 evidenced by confocal microscopy. Int J Exp Pathol. 2003 Apr;84(2):75-81.

Redman R. On approaches to the functional restoration of salivary glands damaged by radiation therapy for head and neck cancer, with a review of related aspects of salivary gland morphology and development. Biotech Histochem. 2008 Jun;83(34):103-30. doi: 10.1080/10520290802374683.

Redman RS, Ball WD. Cytodifferentiation of secretory cells in the sublingual gland of the prenatal rat: a histological, histochemical and ultrastructural study. Am J Anat. 1978 Nov.;153(3):367-89.

Riedl SJ, Salvesen GS. The apoptosome: signalling platform of cell death. Nat Rev Mol Cell Biol. 2007;8(5):405-13.

Rincheval V, Bergeaud M, Mathieu L, Leroy J, Guillaume A, Mignotte B, et al. Differential effects of $\mathrm{Bcl}-2$ and caspases on mitochondrial permeabilization during endogenous or exogenous reactive oxygen species-induced cell death: a comparative study of $\mathrm{H}_{2} \mathrm{O}_{2}$, paraquat, t-BHP, etoposide and TNF- $\alpha$-induced cell death. Cell Biol Toxicol. 2012 Aug;28(4):239-53.

Ritter PM, Marti A, Blanc C, Baltzer A, Krajewski S, Reed JC, et al. Nuclear localization of procaspase- 9 and processing by a caspase-3-like activity in mammary epithelial cells. Eur J Cell Biol. 2000;79(5):358-64.

Ruiz-Vela A, González de buitrago G, Martínez-A C. Nuclear Apaf-1 and cytochrome c redistribution following stress-induced apoptosis. FEBS Letters 2002 Apr;517(13):133-8.

Salvesen GS, Duckett CS. IAP proteins: blocking the road to death's door. Nat Rev Mol Cell Biol. 2002 Jun;3(6):401-10.

Schneyer L, Schneyer C. Inorganic composition of saliva. In: Handbook of Physiology. Baltimore: Williams and Wilkins; 1967. p. 497-530.

Shalini S, Dorstyn L, Dawar S, Kumar S. Old, new and emerging functions of caspases. Cell Death Differ. 2014 Dec;22(4):526-39.

Ship J. Diagnosing, managing, and preventing salivary gland disorders. Oral Dis. 2002 Mar;8(2):77-89. 
Spooner BS, Bassett KE. Embryonic salivary gland epithelial branching activity is experimentally independent of epithelial expansion activity. Dev Biol. 1989 Jun;133(2):569-75.

Streeter G. Weight, sitting height, head size, foot length, and menstrual age of the human embryo. Contrib Embryol.; 1920;11:143-70.

Suzanne M, Steller H. Shaping organisms with apoptosis. Cell Death Differ. 2013 May;20(5):669-75.

Svandova E, Lesot H, Vanden Berghe T, Tucker AS, Sharpe PT, et al. Non-apoptotic functions of caspase-7 during osteogenesis. Cell Death Dis. 2014;5(8):e1366.

Szlávik V , Vág J, Markó K, Demeter K, Madarász E, Oláh I, et al. Matrigel-induced acinar differentiation is followed by apoptosis in HSG cells. J Cell Biochem. 2008 Jan;103(1):284-95.

Tabak LA, Levine MJ, Mandel ID, Ellison SA. Role of salivary mucins in the protection of the oral cavity. J Oral Pathol Med. 1982 Jan;11(1):1-17.

Tait SW, Green DR. Mitochondria and cell death: outer membrane permeabilization and beyond. Nat Rev Mol Cell Biol. 2010;11: 621-32.

Taylor RC, Cullen SP, Martin SJ. Apoptosis: controlled demolition at the cellular level. Nat Rev Mol Cell Biol. 2008;9:231-41.

Ten Cate A. Histologia bucal: desenvolvimento, estrutura e função. $5^{a}$ ed. Rio de Janeiro: Guanabara Koogan; 2001.

Teshima T, Wells KL, Lourenço SV, Tucker AS. Apoptosis in early salivary gland duct morphogenesis and lumen formation. J Dent Res. 2015 Dec 1. pii: 0022034515619581. [Epub ahead of print].

Teshima T, lanez RF, Coutinho-Camillo CM, Buim ME, Soares FA, Lourenço SV. Development of human minor salivary glands: Expression of mucins according to stage of morphogenesis. J Anat. 2011;219:410-7.

Tsujimoto Y, Cossman J, Jaffe E, Croce CM. Involvement of the bcl-2 gene in human follicular lymphoma. Science. 1985;228(4706):1440-3. 
Tucker AS. Salivary gland development. Sem Cell Dev Biol. 2007 Apr;18(2): 237-44.

Tucker AS, Miletitch I. Salivary glands: Development, adaptations and disease. London: Karger; 2010.

Ulukaya E, Acilan C, Yilmaz Y. Apoptosis: Why and how does it occur in biology? Cell Biochem Funct. 2011 Aug;29(6):468-80. doi: 10.1002/cbf.1774.

Uren AG, Wong L, Pakusch M, Fowler KJ, Burrows FJ, Vaux DL, et al. Survivin and the inner centromere protein INCENP show similar cell-cycle localization and gene knockout phenotype. Curr Biol. 2000 Nov;10(21):1319-28.

Vandenabeele P, Berghe T, Vanden Berghe T, Festjens N. Caspase Inhibitors Promote Alternative Cell Death Pathways. Sci STKE. 2006 Oct;2006(658):pe44.

Walker JL, Menko AS, Khalil S, Rebustini I, Hoffman MP, Kreidberg JA, et al. Diverse roles of E-cadherin in the morphogenesis of the submandibular gland: Insights into the formation of acinar and ductal structures. Dev Dyn. 2008;237:3128-41.

Wang D, Liang J, Zhang Y, Gui B, Wang F, Yi X, et al. Steroid receptor coactivatorinteracting protein (SIP) inhibits caspase-independent apoptosis by preventing apoptosis-inducing factor (AIF) from being released from mitochondria. J Biol Chem. 2012;287(16):12612-21.

Wang J, Lenardo MJ. Roles of caspases in apoptosis, development, and cytokine maturation revealed by homozygous gene deficiencies. J Cell Sci. 2000 Mar;113( Pt 5):753-7.

Wang ZH, Ding MX, Chew-Cheng SB, Yun JP, Chew EC. Bcl-2 and Bax proteins are nuclear matrix associated proteins. Anticancer Res. 1999;19(6B):5445-9.

Wei MC, Zong WX, Cheng EH, Lindsten T, Panoutsakopoulou V, Ross AJ, et al. Proapoptotic BAX and BAK: a requisite gateway to mitochondrial dysfunction and death. Science. 2001 May;292(5517):727-30.

Wells KL, Patel N. Lumen formation in salivary gland development. Front Oral Biol. 2010;14:78-89. 
Wiedemann HR, Drescher J. LADD syndrome: report of new cases and review of the clinical spectrum. Eur J Pediatr. 1986 Apr;144(6):579-82.

Wong D. Salivary diagnostics. Ames: Wiley-Blackwell; 2008.

Woo M, Hakem R, Soengas MS, Duncan GS, Shahinian A, Kägi D, et al. Essential contribution of caspase $3 /$ CPP32 to apoptosis and its associated nuclear changes. Genes Dev. 1998;12(6):806-19.

Yin XM, Wang K, Gross A, Zhao Y, Zinkel S, Klocke B, et al. Bid-deficient mice are resistant to Fas-induced hepatocellular apoptosis. Nature. 1999;400(6747):886-91.

Youle RJ, Strasser A. The BCL-2 protein family: opposing activities that mediate cell death. Nat Rev Mol Cell Biol. 2008 Jan;9(1):47-59.

Yuan J, Shaham S, Ledoux S, Ellis HM, Horvitz HR. The C. elegans cell death gene ced-3 encodes a protein similar to mammalian interleukin-1 beta-converting enzyme. Cell. 1993;75(4):641-52. 


\section{UNIVERSIDADE DE SÃO PAULO FACULDADE DE ODONTOLOGIA \\ Comite de ÉTiCa EM Pesouisa}

\section{PARECER de APROVAÇAO \\ Prolocolo 133/11 \\ CAAE 0147.0.017.000-11}

O grupo de trabalho indlcado pelo Comitê de Ética em Pesquisa AProvou o protocolo de pesquisa "Mortogenese das glândulas salivares humanas: Investigaçdo das proleínas e microRNAS emvolvidos no meconlsmo Intínseco da apoptose na formoçāo da esthutura glandular", de responsabilidade da pesquisadora Tathyane Harumi Nakajima Teshima, sob orientaçāo da Profa. Dra. Silvia Vanesso Lourenço.

Tendo em vista a legislaçōo vigente, devem ser encaminhados a este comitê relatórios anuais referentes ao andamento do pesquisa e ao término cópia do trabalho em "cd". Qualquer emendo do projeto original deve ser apresentada a este CEP para apreciaçāo, de forma clara e sucinta, identificando a parte do protocolo a ser modificada e suas justificativas.

Säo Paulo, 13 de dezembro de 2011.

Profa. Dra. Mareia Turolla Wanderley

Coordenadora do CEP-FOUSP 
ANEXO B - Artigos Publicados 


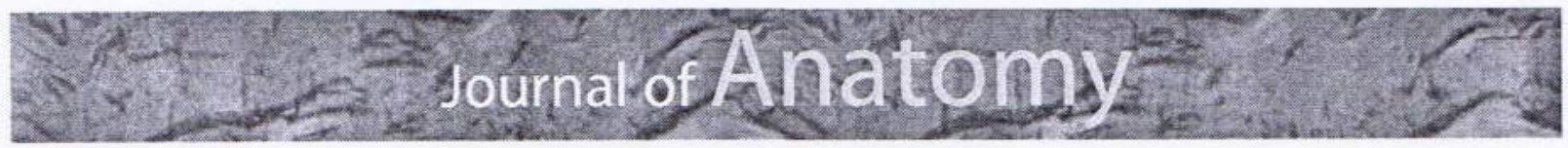

\title{
Development of human minor salivary glands: expression of mucins according to stage of morphogenesis
}

\author{
Fernando A. Soares ${ }^{1,2}$ and Silvia V. Lourenço ${ }^{1,2,3,4}$ \\ 'General Pathology Department, Dental School, University of São Paulo, São Paulo, Brazil \\ ${ }^{2}$ Department of Pathology, A.C. Camargo Hospital, São Paulo, Brazil \\ ${ }^{3}$ Department of Dermatology, Medical School, University of São Paulo, São Paulo, Brazil \\ ${ }^{4}$ Tropical Medicine Institute, University of São Paulo, São Paulo, Brazil
}

Tathyane H. N. Teshima, ${ }^{1}$ Renata F. Ianez, ${ }^{2}$ Claudia M. Coutinho-Camillo, ${ }^{2}$ Marcilei E. Buim, ${ }^{2}$

\begin{abstract}
The formation of salivary glands entails the proliferation of epithelial cells from the stomatodeum into the underlying ectomesenchyme, culminating in a complex network of ducts and acinar bulbs. The extent to which mucins regulate this process is unknown, but they appear to mediate luminal space formation and maturation. Our aim was to examine mucin expression patterns during the morphogenesis of human salivary glands. Mucin expression - MUC1, 2, 3, 4, 5AC, 5B, 6, and 16 - was analyzed in specimens of developing human salivary glands, obtained from fetuses at 4-24 weeks' gestation, and fully developed salivary glands by immunohistochemistry. Expression patterns were analyzed qualitatively according to the development stage of the salivary glands. Mucins 1, 3, 4, 5B, and 16 were expressed during salivary gland development - being stronger in all ductal segments by the final phases of branching morphogenesis and in mature glands. Acinar cells were negative for most mucins, including MUC1 in mature salivary glands. Mucins 2, 5AC, and 6 were not expressed. Mucins $M U C 1,3,4,5 B$, and 16 are expressed in developing human salivary glands and in mature glands, suggesting important roles in the maturation and maintenance of the ductal network.
\end{abstract}

Key words: branching morphogenesis; human salivary glands; mucin.

\section{Introduction}

All salivary glands develop in a similar manner. Formation begins with the proliferation of a solid cord of cells from the epithelium of the stomatodeum into the underlying ectomesenchyme. This cord of cells extends deeply into the ectomesenchyme and branches extensively. Canalization occurs and degradation of the central cells to form the ductal system and the terminal secretory end pieces. The epithelial ingrowths constitute the parenchyma of a salivary gland. The ectomesenchyme differentiates into the connective tissue component of the gland, which supports the glandular parenchyma (Dale, 1994; Klein, 1994; Lourenço et al. 2007, 2008).

Correspondence

Silvia Vanessa Lourenço, Faculdade de Odontologia da Universidade de São Paulo, Disciplina de Patologia Geral, Av Professor Lineu Prestes, 2227, Cidade Universitária CEP, 05508-000 Săo Paulo-SP, Brazil. $T:+551130617062 ; F:+551130617062 ;$ E: silvialourenco.70@ terra.com.br; silvialourenco@usp.br; tathyharumi@gmail.com

Accepted for publication 20 May 2011 Article published online 16 June 2011
At the end of maturation, salivary glands are ready to produce saliva, which occurs in two phases: an acinar phase, during which primary saliva is generated, and a ductal phase of electrolyte resorption, resulting in hypotonic saliva. The final composition of saliva is complex, comprising electrolytes, immunoglobulins, proteins, enzymes, nitrogenous products, and mucins. This amalgam has many functions in maintaining oral health (Guyton \& Hall, 2000; Humphrey \& Williamson, 2001).

Mucins are the chief glycoprotein components of saliva and other mucous secretions and have many biological actions, such as protection of mucosal surfaces from adverse environmental influences, facilitation of glandular secretion, promotion and modulation of cell adhesion, and regulation of signaling (Braga et al. 1992; Hilkens et al. 1992; Komatsu et al. 2000; Chaturvedi et al. 2008).

In the oral cavity, mucins mediate the protection of dental surfaces against chemical (demineralization and proteolytic degradation) and mechanical (attrition and abrasion) damage. They also prevent caries by limiting bacterial adhesion and controlling oral infection, inhibiting the colonization of pathogenic microbes (Zalewska et al. 2000; Liu et al. 
2002; Piras et al. 2010). Mucins regulate the lubrication of the mucosal surface, benefiting physiological functions such as mastication, speech, and swallowing. Further, they prevent mucosal desiccation, based on their capacity to retain water (Nieuw Amerongen et al. 1995; Humphrey \& Williamson, 2001; Sonesson et al. 2008).

Mucins are synthesized by epithelial cells and, in some cases, endothelial cells (Hollingsworth \& Swanson, 2004; Zhang et al. 2005; Chaturvedi et al. 2008). Nearly 20 mucin (MUC)-encoding genes have been described, some of which have been well characterized (Ho et al. 1993; Gendler \& Spicer, 1995). Mucins are membrane-bound (transmembranic) (MUC1, MUC3, MUC4, MUC12, and MUC17), encoded by the $7 q 22,3 q$, and $1 q 21$ loci, or secretory (gel-forming) (MUC2, MUC5AC, MUC5B and MUC6), encoded primarily by the $11 \mathrm{p} 15$ locus and restricted to secretory organs and certain cell types (Awaya et al. 2004; Handra-Luca et al. 2005; Chaturvedi et al. 2008). Other products of certain MUC genes do not belong to either class (MUC7, MUC8, MUC9, MUC13, MUC15, and MUC16) (Sasaki et al. 2007).

The expression of each MUC gene is specific to an organ, tissue, or cell type (Nieuw Amerongen et al. 1995; Alos et al. 2005). Some mucins are expressed in most epithelial and glandular tissues, such as in pancreas (MUC1), breast (MUC1), the gastrointestinal (MUCs3, 4, 5AC, 5B, 6, 17) and respiratory tracts, tracheobronchial mucosa (MUC 2, 4, 5AC, $5 B, 6)$, gallbladder (MUC3), and salivary glands $(1,2,5 A C$, 5B, 6, 7, 16) (Ho et al. 1993; Alos et al. 2005; Chaturvedi et al. 2008, Piras et al. 2010). MUC5B is also expressed in the endocervix, respiratory tract, gallbladder, and colon (Audie et al. 1993; Porchet et al. 1995; van Klinken et al. 1998).

The expression patterns of mucins in fully developed salivary glands and salivary gland neoplasms have been described recently (Liu et al. 2002; Alos et al. 2005; HandraLuca et al. 2005; Piras et al. 2010). But such patterns in salivary gland tissue have not been determined, and mucin expression during human salivary gland morphogenesis has not been reported. The purpose of this study is to determine the distribution of mucins during human salivary gland development and its relationship with gland morphology and maturation.

\section{Materials and methods}

\section{Tissue preparation}

Fragments from the oral cavity of 20 postmortem human fetuses (from natural miscarriages) were used. The fetuses were at 424 weeks' gestation and were obtained from the Medical School of the University of São Paulo, with permission from the ethical committee of the institution.

The specimens were collected from the buccal mucosa, tongue, mandible, and hard palate. Specimens of fully developed salivary glands from oral mucosa biopsies were retrieved from the archives of the Laboratory of Dermatopathology of the same institution and used as controls. Histologically, they were normal and exhibited no inflammation or neoplasms.

All specimens were fixed in $10 \%$ buffered formalin for $24 \mathrm{~h}$ and embedded in paraffin. They were then processed histologically, serial-sectioned, and stained with hematoxylin and eosin to determine the presence of salivary glands and study their morphology. Specimens that contained developing minor salivary glands were selected for the immunohistochemical analysis ( 80 specimens). The expression of MUC1, 2, 3, 4, 5AC, 5B, 6, and 16 was examined in all developing salivary gland samples and controls.

\section{Immunohistochemistry}

Serial sections of $4 \mu \mathrm{m}$ of the developing salivary gland samples were deparaffinized, rehydrated, and subjected to antigen retrieval. The antigen retrieval methods and primary antibody clones, sources, and names are listed in Table 1. The sections were incubated in $3 \%$ aqueous hydrogen peroxide for $15 \mathrm{~min}$ to quench endogenous peroxidase activity and with Protein Block Serum-Free (DakoCytomation, Carpinteria, CA, USA) for $20 \mathrm{~min}$ at room temperature to prevent nonspecific binding of subsequent reagents.

The samples were incubated with primary antibody for $2 \mathrm{~h}$ at room temperature. The antigen-antibody complexes were visualized using the Advance system (DakoCytomation) and developed with 3' 3-diaminobenzidine tetrachloride (DAB) (DakoCytomation) for $5 \mathrm{~min}$. The sections were then counterstained with Mayer's hematoxylin, dehydrated, and mounted with glass coverslips and xylene-based mounting media. All immunohisto chemical reactions and analyses were performed in duplicate.

The slides were examined on a conventional optical microscope that was equipped with a digital camera for photographic registration.

Table 1 Antibody sources, clones, and working protocols.

\begin{tabular}{llll}
\hline Primary serum & Source & Clone & Titer \\
\hline MUC1 & Novocastra, Benton Lane, Newcastle, UK & Ma695 & $1: 2000$ \\
MUC2 & Novocastra & Ccp58 & $1: 2000$ \\
MUC3 & Neomarkers, Fremont, CA, USA & $1143 / \mathrm{B} 7$ & $1: 700$ \\
MUC4 & Zymed, San Francisco, CA, USA & 1 G8 & $1: 800$ \\
MUC5AC & Novocastra, Benton Lane, Newcastle, UK & CLH2 & $1: 1000$ \\
MUC5B & LifeSpan, Seattle, WA, USA & Muc5b & $1: 100$ \\
MUC6 & Novocastra & CLH5 & $1: 2000$ \\
MUC16 & Abcam, Washington, DC, USA & X75 & Citrate buffer/pH 6.0 \\
& & & Citrate buffer/pH 6.0 \\
\hline
\end{tabular}


As negative controls, the specimens were incubated with nonimmune serum. Positive controls were included as per the manufacturer's recommendations.

\section{Results}

The specimens were minor human salivary glands at various stages of development, comprising the initial, pseudoglandular, canalicular, and terminal buds (Fig. 1), according to the stages of salivary gland morphogenesis proposed by Tucker (2007). The results concerning salivary gland morphology and morphogenetic stage are shown in Table 2.

\section{Immunohistochemistry}

MUC 1, 3, 4, 5B, and 16 was expressed in various phases of human salivary gland development and in mature human salivary glands. Mucins MUC 2, 5AC, and 6 were not expressed in any specimen.

At the initial bud stage, when salivary glands begin to develop, only MUC1 was detected around a few clusters of cells (Fig. $2 A 1, A 2$ ), and MUC5B and 16 were expressed weakly in some cells (Fig. $3 A 1, B 1$ ). At this stage, MUC3 and MUC4 were not present (Fig. 2A3,A4).

At the pseudoglandular stage, MUC1 was observed as brown deposits in the rudimentary luminal space (Fig. 2B1). In this phase, MUC3 staining was faint in the vessel walls at the initial phase of canalization but formed small cytoplasmic deposits in the glandular cells of future ductal structures as this phase of glandular morphogenesis progressed (Fig. 2B2). MUC4 expression was robust in the luminal pole of luminal cells (Fig. 2B3). MUC5B and 16 were poorly expressed in the luminal space in all specimens (Fig. 3A1,B1).

MUC1, 3, and 4 were present in the canalicular stage of salivary gland morphogenesis. MUC1 appeared in the luminal space of all glandular ductal systems, and MUC4 was expressed only in the luminal space of well-developed excretory ducts, but not to a greater extent than MUC1 (Fig. 2C1,C3). MUC4 was also observed in blood vessel walls (Fig. 2C3 - arrow), similar to MUC5B (Fig. 3A3). MUC3 was expressed in the cytoplasm of ductal cells (Fig. 2C2). MUC5B and 16 were not expressed at this stage of morphogenesis.

During the terminal bud stage, MUC1 maintained its strong expression along the luminal pole of luminal cells throughout the entire ductal system (Fig. 2D1,D2). Further, MUC1 was expressed in the cytoplasm of basal cells of larger excretory ducts in certain areas (Fig. 2D1). MUC3 was present in the cytoplasm of many glandular cells - in all ductal portions (intercalated, interlobular and excretory extralobular ducts), and in the demilune structures around acinar lobules (Fig. 2D3). MUC4 maintained its positivity only in the luminal pole of luminal cells of larger excretory ducts (Fig. 2D4). MUC3 and MUC4 were also expressed in
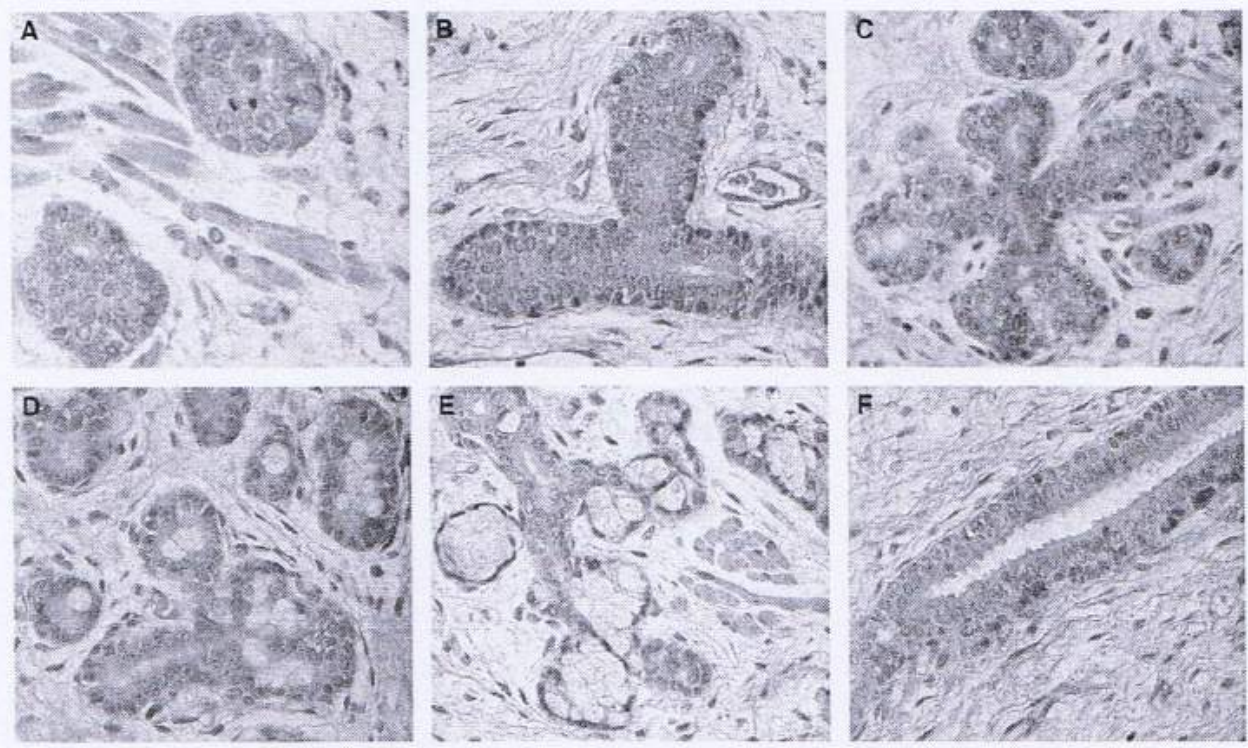

Fig. 1 Morphological phases of human salivary gland development. (A) Initial bud: solid nests of epithelial cells surrounded by a loose mesenchyme (original magnification $\times 400$ ). (B) Pseudoglandular stage: solid cords of epithelial cells with central vestigial luminal spaces (original magnification $\times 400$ ). (C) Canalicular stage: proliferation of the glandular structure, forming a complex network of canalized structures (original magnification $\times 400$ ). (D) Terminal bud - initial stage: presence of terminal bulbs composed of cells with large and clear cytoplasm (original magnification $\times 400$ ). (E) Terminal bud - advanced stage: presence of well established acinar lobules (original magnification $\times 400$ ). ( $F$ ) Well developed excretory duct composed of multiple layers of epithelial cells. Note the secretion of eosinophilic material (mucous material) on the luminal pole of luminal cells (original magnification $\times 400$ ). 
Table 2 Semiquantitative expression of mucins during human salivary gland morphogenesis and in fully developed salivary glands.

\begin{tabular}{|c|c|c|c|c|c|c|c|c|}
\hline & MUC1 & MUC2 & MUC3 & MUC4 & MUC5AC & MUC5B & MUC6 & MUC16 \\
\hline \multicolumn{9}{|c|}{$\begin{array}{l}\text { Developing human salivary gland } \\
\text { ( } 80 \mathrm{sp)}\end{array}$} \\
\hline \multicolumn{9}{|c|}{ Initial bud (6 sp) } \\
\hline Epithelial cells & + & 0 & 0 & 0 & 0 & 0 & 0 & 0 \\
\hline Stroma & 0 & 0 & 0 & 0 & 0 & 0 & 0 & 0 \\
\hline \multicolumn{9}{|c|}{ Pseudoglandular (24 sp) } \\
\hline Luminal space & +++ & 0 & 0 & 0 & 0 & 0 & 0 & + \\
\hline Ductal cells & + & 0 & + & + & 0 & + & 0 & 0 \\
\hline \multicolumn{9}{|c|}{ Canalicalicular (40 sp) } \\
\hline Luminal space & +++ & 0 & 0 & + & 0 & 0 & 0 & ++ \\
\hline Ductal cells & + & 0 & ++ & 0 & 0 & ++ & 0 & 0 \\
\hline \multicolumn{9}{|c|}{ Terminal bud (10 sp) } \\
\hline Acinar cells & 0 & 0 & 0 & 0 & 0 & 0 & 0 & +++ \\
\hline Ductal cells & +++ & 0 & ++ & + & 0 & +++ & 0 & 0 \\
\hline Luminal space & ++ & 0 & 0 & ++ & 0 & 0 & 0 & ++ \\
\hline \multicolumn{9}{|l|}{$\begin{array}{l}\text { Adult salivary glands } \\
(6 \mathrm{sp})\end{array}$} \\
\hline Acinar cells & +++ & 0 & + & + & 0 & 0 & 0 & +++ \\
\hline Ductal cells & 0 & 0 & + & +++ & 0 & ++ & 0 & 0 \\
\hline Luminal space & + & 0 & 0 & 0 & 0 & 0 & 0 & 0 \\
\hline Blood vessels & 0 & 0 & +++ & +++ & 0 & ++ & 0 & 0 \\
\hline
\end{tabular}

+, weak expression; ++, moderate expression; +++, strong expression; 0 , negative; sp, specimens.

the luminal border of blood vessel walls (Fig. 2D4 - arrow). All these three mucins were absent in well-developed acinar structures, and MUC5B and 16 were highly expressed in mucous cells (Fig. 3A2,B2). In minor mucous salivary glands, MUC5B was not expressed, and MUC16 was present only at the luminal pole of ductal cells and as deposits in the luminal space (Fig. 3A3,B3).

In fully developed salivary glands, MUC1 was detected in the cytoplasm of acinar cells and in the luminal space border of the ducts (Fig. 4A). MUC3 and MUC4 were expressed in ductal cells, acinar lobules, and blood vessels (Fig. 4B, C1 and (2). MUC3 staining was faint in the cytoplasm of ductal cells, whereas MUC4 was intense in several layers of cells that constitute the excretory ducts (Fig. 4C2). MUC5B was detected in the luminal border of excretory ducts, and MUC16 was observed in acinar cells and the luminal border of excretory ducts (Fig. 4D1 and D2, respectively).

\section{Discussion}

This study demonstrates the expression of a panel of mucins throughout human salivary gland development. Each mucin has been suggested to have disparate properties, e.g. an epidermal growth factor-like domain, a transmembrane region, and a capacity to form gels, conferring diverse functions (Sasaki et al. 2007). This model is supported by our results.

Five of the eight mucins that we examined were positive throughout human salivary gland morphogenesis: MUC1,
MUC3, MUC4, MUC5B, and MUC16. Further, the expression of each of these mucins varied, depending on glandular developmental phase. MUC2, 5AC, and 6 were not detected in our specimens; according to Alos et al. (2005), they are negative or only focally expressed in certain fully developed salivary glands, confirming our findings.

MUC1 and MUC4 are the best-characterized membraneassociated mucins in salivary glands and are classified structurally as monomers. MUC3 is also considered a membrane-bound mucin (Liu et al. 2002). Whereas the functions of gel-forming mucins are believed to be primarily protective, the functions of membrane-associated mucins are poorly understood, although recent evidence suggests that they mediate signal transduction cascades, a function that is believed to be linked to the presence of EGF-like motifs in MUC3A, MUC3B, MUC4, MUC12, and MUC17. Such domains might modulate epithelial growth, which explains in part the expression of MUC3 and 4 during salivary gland morphogenesis.

Although the mechanisms by which these mucins function in human salivary glands are unknown, Liu et al. (2002) demonstrated that MUC1 and MUC4 in fully developed parotid and submandibular glands and membrane-associated mucins might regulate the signaling pathways that govern their normal and physiological functions.

Despite this significant evidence on mucin function in fully developed glands, there is very little information available on mucin expression in human salivary gland development. Nevertheless, MUC1 is an important glycoprotein that might 


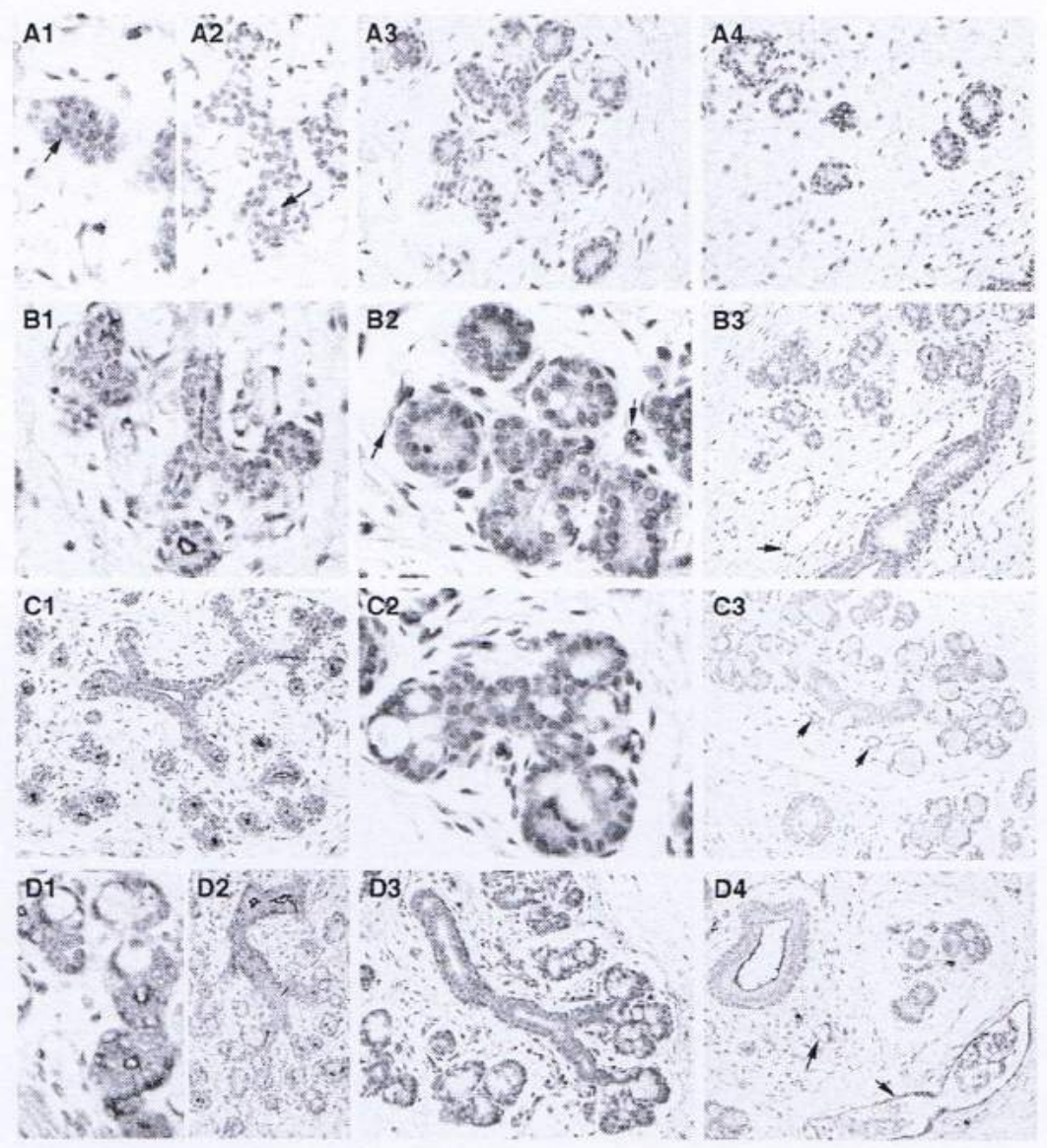

Fig. 2 Expression of MUC1, 3, and 4 in developing human salivary glands. (A1-A4) Initial bud: (A1,A2) Minimal expression of MUC1 in the epithelial cords (arrows). (A3,A4) No MUC3 or 4 at this stage of glandular development. Original magnification: $\times 400$. (B1-B3) Pseudoglandular stage: (B1) MUC1 in the luminal space of canalizing structures. (B2) Mucin MUC3 - diffuse expression in the cytoplasm of epithelial cells. Expression of this mucin was also observed in blood vessel walls (arrows). (B3) Weak expression of MUC4 mainly in the luminal space of the ductal system and in blood vessel walls (arrows). Original magnification: $\times 400$ (B1), $\times 600$ (B2), and $\times 250$ (B3). (C1-C3) Canalicular stage: (C1) Strong expression of MUC1 in the luminal spaces of the ductal system. (C2) Weak expression of MUC3 in ductal cell cytoplasm, mainly in the basal pole. (C3) Weak expression of MUC4 in the luminal pole of ducts and in blood vessel walls (arrows). Original magnification: $\times 150$ (C1), $\times 600$ (C2), and $\times 400$ (C3). (D1-D4) Terminal bud: (D1,D2) Strong expression of MUC1 in the luminal space of the ductal system and in the basal pole of excretory duct cell cytoplasm. (D3) Expression of MUC3 in the cytoplasm of ductal cells and in some demilune structures. (D4) Presence of MUC4 in blood vessel walls (arrows) and in the luminal space of excretory ducts. Original magnification: $\times 600$ (D1), $\times 150$ (D2), $\times 400$ (D3), $\times 400(D 4)$

facilitate the flow of secretions through the ductal system (Liu et al. 2002). We detected MUC1 deposits at the bud phase, immediately before morphological evidence of epithelial cord proliferation and canalization. Braga et al. (1992) observed that MUC1 lines the luminal border of epithelia that fold and branch, even before the completion of organ maturation; this pattern is also observed in salivary glands. MUC1 deposits increased gradually with subsequent luminal opening during salivary gland morphogenesis, and its expression was greater in pseudoglandular and canalicular phases, primarily in the luminal pole of epithelial cells.

These results are consistent with those of other groups. Alos et al. (2005) noted MUC1 primarily in the apical pole of normal salivary glands ductal cells, as observed by other investigators in various tubular organs (Braga et al. 1992), strengthening a model in which MUC1 expression is induced concomitantly with epithelial differentiation in individual organs.

High MUC1 expression decreases cell-cell interactions on the luminal surface of ducts, which likely facilitates lumen formation and maintenance by reducing adhesive associations in the apical domain (Lightenberg et al. 1992). Moreover, the structure and biochemical properties of MUC1 might help prevent interactions between adhesive molecules, favoring the maintenance of luminal spaces. The maintenance of the luminal space might also be aided by the expression of other mucins; this hypothesis is supported by our results, in which MUC4 is expressed in the late stages 

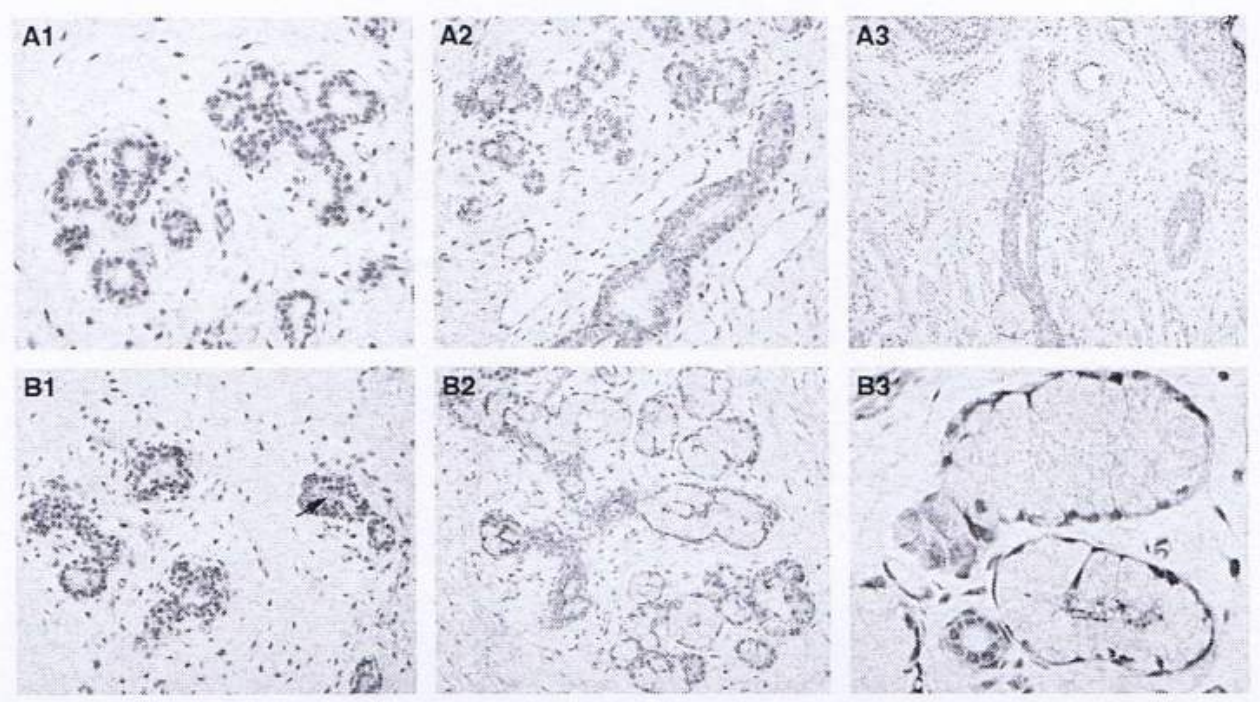

Fig. 3 Expression of MUC5B and 16 in developing human salivary glands. (A1,B1) Pseudoglandular stage: (A1) No MUC5B at this stage of glandular development. (B1) MUC 16 in several ductal lumens (arrow). Original magnification: $\times 400$. (A2,B2) Canalicular stage: (A2) MUC5B in the luminal space of canalized ducts. (B2) MUC16 in the luminal spaces of well canalized and differentiated glandular structures. Acinar lobules positive for MUC16 in the central spaces. Original magnification $\times 400$. (A3,B3) Terminal bud: (A3) Strong expression of MUC5B in the luminal spaces of the ductal system. (B3) MUC16 in the central space of acinar lobules. Luminal borders of ducts are negative. Original magnification: $\times 400(\mathrm{A3})$ and $\times 600(\mathrm{B3})$.

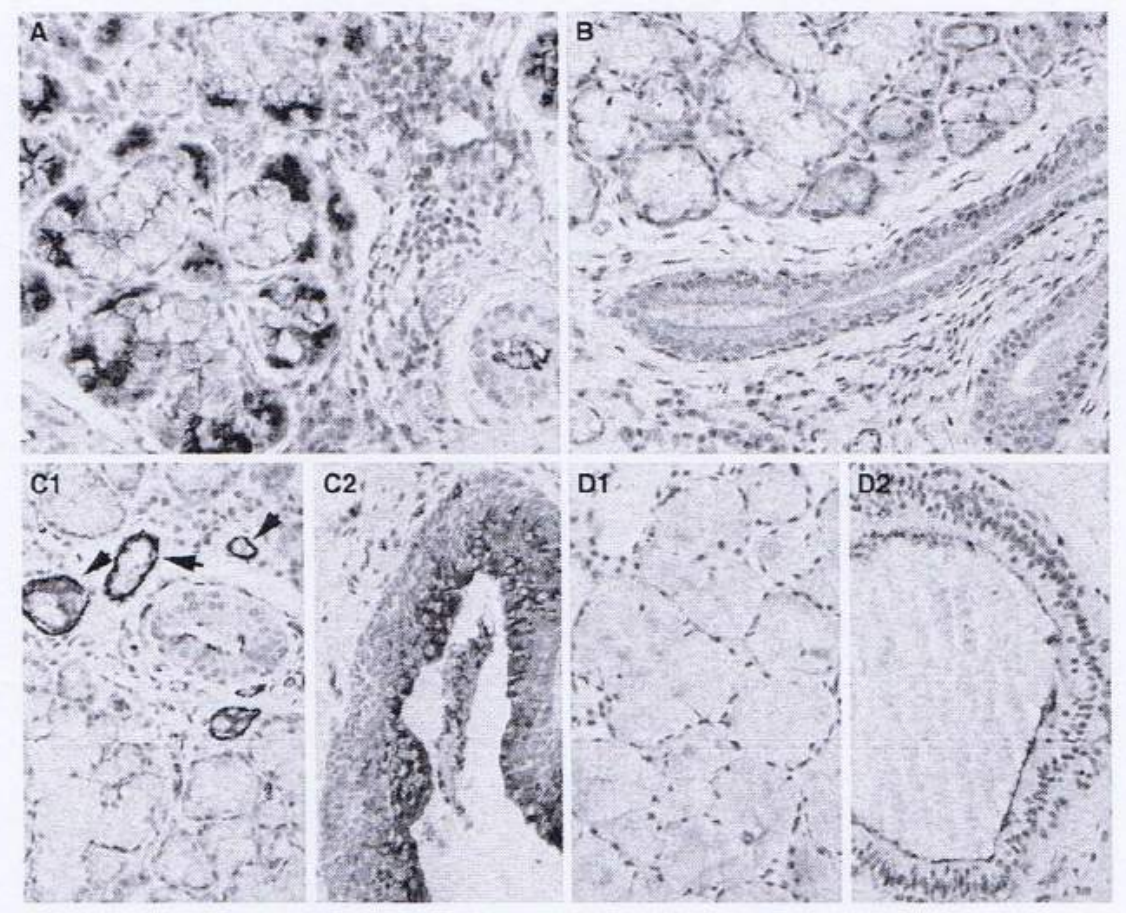

Fig. 4 Expression of MUC1, 3, 4, and 16 in fully developed human salivary glands. (A) Expression of MUC1 in the cytoplasm of acinar cells and in the luminal portions of ducts. Original magnification: $\times 400$. (B) Presence of MUC3 in the cytoplasm of ductal cells and in myoepithelial cells. Original magnification: $\times 400$. (C) MUC4 expressed in the luminal portion of interlobular ducts (C1) and in blood vessel walls (C1 arrows). Marked expression of MUC4 in excretory ducts (C2). Original magnification: $\times 400$. (D) Expression of MUC16 in acinar cells (D1) and luminal border of excretory ducts (D2). Original magnification: $\times 400$. 
of salivary gland morphogenesis, when ductal lumina are already well formed, especially on the luminal surface of excretory ducts.

MUC4 is expressed in many normal epithelial tissues during development and in adults (Gendler \& Spicer, 1995; Van Klinken et al. 1995; Zhang et al. 2006). During development, MUC4 levels rise progressively with gestational age, and in certain sections of the digestive tube, its expression correlates with the stage of differentiation (Zhang et al. 2006). This fact was observed in our results - MUC4 expression increased as gland maturation occurred and was more significant in the squamous epithelium of excretory ducts. Other groups have documented expression of MUC4 in excretory, striated, and intercalated ducts and moderate expression in acinar structures of the parotid submandibular gland and other minor salivary glands (Liu et al. 2002; Alos et al. 2005).

The expression of MUC1 and MUC4 in the late stages of salivary gland morphogenesis might be indicative of their other physiological functions in the fully developed gland, such as facilitation of salivary flow secretion through the duct system and interactions with other molecules on oral epithelial surfaces for further association with the gel-forming mucin MUC5B, which has protective functions as part of MG1 (Liu et al. 1998). This latter function has been ascribed to MUC4 in the breast milk of humans and other mammals (Zhang et al. 2005; Ruvoen-Clouet et al. 2006; Chaturvedi et al. 2008).

Moreover, MUC1 and MUC4 are modulators of cell signaling, whereby MUC1 acts as a docking protein for signaling pathways and MUC4 regulates the receptor tyrosine kinase ErbB2 (Carraway et al. 2002; Zhang et al. 2006). These MUCs might participate in such mechanisms during salivary gland development, a hypothesis that should be examined in future studies.

The membrane-bound mucin MUC 3 was detected in the pseudoglandular/canalicular phases of salivary gland morphogenesis in the cytoplasm of cells that compose the glandular ductal system. The cysteine (Cys)-rich domain of MUC3 and its epidermal growth factor-like domains govern epithelial growth and function in epithelial restitution. Therefore, MUC3 expression in salivary gland morphogenesis might be crucial for the growth and determination of the final shape of the ductal system and can be developed as a novel therapeutic agent in inflammatory glandular diseases, as proposed by $\mathrm{Ho}$ et al. (2006) for intestinal wound healing.

MUC5B is the chief mucin in human saliva, originally termed MG1. It is a high-molecular-weight oligomeric glycoprotein that is the principal secretory product of mucous acini of the submandibular, sublingual, and palatal glands (Piras et al. 2010). Notably, MUC5B was expressed in blood vessel walls. In an excellent review on the structure and biosynthesis of salivary gland mucins, Zalewska et al. reported that six subdomains of the C-terminal region of MUC5B have conserved sequences that are similar to those in von Willebrand factor, which is expressed in the subendothelial area of most blood vessels (Sadler, 1998; Zalewska et al. 2000). Thus, the MUC5B expression in blood vessels walls might have been due to cross-reaction with its VWF homolog. We are testing this hypothesis.

In contrast to MUC5B, there are no data on the expression of MUC16 in human salivary glands. This protein is primarily expressed in human nasal mucosa, corneal epithelial cells, and ovarian cancers (Davies et al. 2007; Woo et al. 2010).

Whereas MUC1, 3, and 4 levels were highest at the initial stages of the developmental human salivary glands that we analyzed, MUC5B and 16 were more important during the final stages of their development, when mucus production begins. According to Alos et al. (2005) and Piras et al. (2010), MUC5B is robustly expressed in the cytoplasm of mucous acini of all normal submandibular and minor salivary glands.

An understanding of the expression of certain mucins in the early phases of glandular morphogenesis might allow us to comprehend the reported expression of mucins in salivary gland neoplasms. Hamada et al. (2004) have shown that MUC1 expression in pleomorphic adenomas is associated with tumor recurrence. Other groups have linked MUC1 expression with a poor prognosis in mucoepidermoid carcinomas (Hilkens et al. 1992; Alos et al. 2005). It is possible that MUC1 regulates cell migration and invasion during embryogenesis and organ formation and with regard to the invasiveness of neoplastic cells. This issue, however, merits further investigation using experimental approaches to evaluate MUC1 as a prognostic marker of salivary gland neoplasms.

\section{Author contributions}

Tathyane Harumi N. Teshima contributed to the study design, acquisition of data, data analysis, interpretation, and manuscript drafting. Renata Fraga lanez, Claudia M. Coutinho-Camillo, and Marcilei E. Buim contributed to the study design, acquisition of data, data analysis, and interpretation. Fernando A. Soares and Silvia V. Lourenço contributed to the study concept and design, data interpretation, critical revision of the manuscript, and final approval of the materials and manuscript.

\section{References}

Alos L, Lujan B, Castillo M, et al. (2005) Expression of membrane-bound mucins (MUC-1 and MUC-4) and secreted mucins (MUC-2, MUC-5AC, MUC-5B, MUC-6 and MUC7) in mucoepidermoid carcinomas of salivary glands. Am J Surg Pathol 29, 806-813.

Audie JP, Janin A, Porchet N, et al. (1993) Expression of human mucin genes in respiratory, digestive, and reproductive tracts ascertained by in situ hybridization. J Histochem Cytochem 41, 1479-1485. 
Awaya H, Takeshima Y, Yamasaki M, et al. (2004) Expression of MUC-1, MC-2, MUC-5AC, and MUC-6 in atypical adenomatous hyperplasia, bronchioloalveolar carcinoma, adenocarcinoma with mixed subtypes, and mucinous bronchioloalveolar carcinoma of the lung. Am J Clin Pathol 121, 644-653.

Braga VMM, Pemberton LF, Duhig T, et al. (1992) Spatial and temporal expression of an epithelial mucin, Muc-1, during mouse development. Development 115, 427-437.

Carraway LK, Perez A, Idris N, et al. (2002) MUC4/sialomucin complex, the intramembrane ErbB2 ligand, in cancer and epithelia: to protect and to survive. Prog Nucleic Acids Res Mol Biol 171, 149-185.

Chaturvedi P, Singh AP, Batra SK (2008) Structure, evolution and biology of the MUC4 mucin. FASEB / 22, 966-981.

Dale AC (1994) Salivary gland. In: Oral Histology, 4th edn (ed. Ten (ate AR), pp. 312-333. St. Louis: Mosby.

Davies J, Kirkham S, Svitacheva N, et al. (2007) MUC16 is produced in tracheal surface epithelium and submucosal glands and is present in secretions from normal human airway and cultured bronchial epithelial cells. Int $\int$ Biochem Cell Biol 39, 1943-1954.

Gendler SJ, Spicer AP (1995) Epithelial mucin genes. Annu Rev Physiol 57, 607-634.

Guyton AC, Hall JE (2000) Textbook of Medical Physiology, 10th edn. pp. 738-753. Philadelphia: WB Saunders Company.

Hamada T, Matsukita S, Goto M, et al. (2004) Mucin expression in pleomorphic adenoma of salivary gland: a potential role for MUC1 as a marker to predict recurrence. I Clin Pathol 57, 813-821.

Handra-Luca A, Lamas G, Jacques-Charles B, et al. (2005) MUC 1 , MUC 2, MUC 4 and MUC $5 A C$ expression in salivary gland mucoepidermoid carcinoma - diagnostic and prognostic implications. Am I Surg Pathol 29, 881-889.

Hilkens J, Ligtenberg JL, Vos HL, et al. (1992) Cell membraneassociated mucins and their adhesion-modulating property. Trends Biochem Sci 17, 359-363.

Ho SB, Niehans GA, Lyftogt C, et al. (1993) Heterogeneity of mucin gene expression in normal and neoplastic tissues. Cancer Res 53, 641-651.

Ho SB, Dvorak LA, Moor RE, et al. (2006) Cysteine-rich domains of MUC3 intestinal mucin promote cell migration, inhibit apoptosis, and accelerate wound healing. Gastroenterology 131, 1501-1517.

Hollingsworth MA, Swanson BJ (2004) Mucins in cancer: protection and control of the cell surface. Nat Rev Cancer 4, 45-60.

Humphrey SP, Williamson RT (2001) A review of saliva: normal composition, flow and function. J Prosthet Dent 85, 162-169.

Klein RM (1994) Development, structure and function of salivary glands. In: Oral Development and Histology, 2nd edn (ed. Avery JK), pp. 352-379. New York: Thieme.

van Klinken BJ, Dekker J, van Gool SA, et al. (1998) MUC5B is the prominent mucin in human gallbladder and is also expressed in a subset of colonic goblet cells. Am J Physiol 274, G871-G878.

Komatsu M, Tatum L, Altman NH, et al. (2000) Potentiation of metastasis by cell surface sialomucin complex (MUC4), a multifunctional anti-adhesive glycoprotein. Int J Cancer 87, 480-486.
Lightenberg MJL, Kruijshaar L, Buijs F, et al. (1992) Cell associated episialin is a complex containing two proteins derived from a common precursor. J Biol Chem 267, 6171-6177.

Liu B, Offner GD, Nunes DP, et al. (1998) MUC4 is a major component of salivary mucin MG1 secreted by the human submandibular gland. Biochem Biophys Res Commun 250, 757-761.

Liu B, Lague JR, Nunes DP, et al. (2002) Expression of membrane-associated mucins MUC1 and MUC4 in major human salivary glands. I Histochem Cytochem 50, 811-820.

Lourenço SV, Coutinho-Camillo CM, Buim MEC, et al. (2007) Human salivary gland branching morphogenesis: morphological localization of claudins and its parallel relation with developmental stages revealed by expression of cytoskeleton and secretion markers. Histochem Cell Biol 128, 361-369.

Lourenço SV, Uyekita SH, Lima DMC, et al. (2008) Developing human minor salivary glands: morphological parallel relation between the expression of TGF-beta isoforms and cytoskeletal markers of glandular maturation. Virchows Arch 452, 427-434.

Nieuw Amerongen AV, Bolscher JGM, Veerman ECI (1995) Salivary mucins: protective functions in relation to their diversity. Glycobiology 5, 733-740.

Piras M, Hand AR, Tore G, et al. (2010) Ultrastructural localization of salivary mucins MUC5B and MUC7 in human labial glands. Eur J Oral Sci 118, 14-18.

Porchet N, Pigny P, Buisine MP, et al. (1995) Human mucin genes: genomic organization and expression of MUC4, MUC5AC and MUC5B. Biochem Soc Trans 23, 800-805.

Ruvoen-Clouet N, Mas E, Marionneau S, et al. (2006) Bile-saltstimulated lipase and mucins from milk of 'secretor' mothers inhibit the binding of Norwalk virus capsids to their carbohydrate ligands. Biochem J 393, 626-634.

Sadler JE (1998) Biochemistry and genetics of Von Willebrand Factor. Annu Rev Biochem 67, 395-424.

Sasaki M, Ikeda H, Nakanuma Y (2007) Expression profiles of MUC mucins and trefoil factor family (TFF) peptides in the intrahepatic biliary system: physiological distribution and pathological significance. Prog Histochem Cytochem 42, 61-110. Sonesson M, Wickström C, Kinnby B, et al. (2008) Mucins MUC5B and MUC7 in minor salivary gland secretion of children and adults. Arch Oral Biol 53, 523-527.

Tucker AS (2007) Salivary gland development. Semin Cell Dev Biol 18, 237-244.

Van Klinken BJW, Decker J, Buller HA, et al. (1995) Mucin gene structure and expression: protection vs. adhesion. Am J Physiol 269, G613-G627.

Woo H, Bae CH, Song S, et al. (2010) Expression of membranebound mucins in human nasal mucosa. Different patterns for MUC4 and MUC16. Arch Otolaryngol Head Neck Surg 136, 603-609.

Zalewska A, Zwierz K, Zólkowski K, et al. (2000) Structure and biosynthesis of human salivary mucins. Acta Biochim Pol 47, 1067-1079.

Zhang J, Perez A, Yasin M, et al. (2005) Presence of MUC4 in human milk and at the luminal surfaces of blood vessels. J Cell Physiol 204, 166-177.

Zhang J, Yasin M, Carraway CAC, et al. (2006) MUC4 expression and localization in gastrointestinal tract and skin of human embryos. Tissue Cell 38, 271-275. 


\title{
Apoptosis in Early Salivary Gland Duct Morphogenesis and Lumen Formation
}

\author{
T.H.N. Teshima', K.L. Wells ${ }^{2}$, S.V. Lourenço', \\ and A.S. Tucker ${ }^{2}$
}

\begin{abstract}
Salivary glands are essential for the maintenance of oral health by providing lubrication and antimicrobial protection to the mucosal and tooth surfaces. Saliva is modified and delivered to the oral cavity by a complex multifunctional ductal system. During development, these ducts form as solid tubes, which undergo cavitation to create lumens. Apoptosis has been suggested to play a role in this cavitation process along with changes in cell polarity. Here, we show that apoptosis occurs from the very earliest stages of mouse salivary gland development, much earlier than previously reported. Apoptotic cells were observed in the center of the first epithelial stalk at earlystage embryonic day 12.5 (EI2.5) according to both TUNEL staining and cleaved caspase 3 immunofluorescence. The presumptive lumen space was highlighted by the colocalization of a predictive lumen marker, cytokeratin 7. At EI4.5, as lumens start to form throughout the glands, apoptotic expression decreased while cytokeratin 7 remained positive. In vitro inhibition of all caspases in EI2.5 and EI3.5 salivary glands resulted in wider ducts, as compared with the controls, and a defect in lumen formation. In contrast, no such defect in lumen formation was observed at EI4.5. Our data indicate that apoptosis is involved during early stages of gland formation (EI2.5 onward) and appears important for shaping the forming ducts.
\end{abstract}

Keywords: embryonic development, salivary ducts, cell death, caspases, keratins, developmental biology

\section{Introduction}

During epithelial organogenesis, lumen formation within an initially solid tube is essential for building functional networks of epithelial tubes in different organs, such as mammary and salivary glands (SGs) (Mailleux et al. 2007; Kwon and Larsen 2015). It has been postulated that canalization of SG ducts and other glands is due to clearance of the inner cell population within newly branched epithelial stalks by apoptosis, a form of programmed cell death. Lumen formation therefore occurs secondarily to branching morphogenesis (Lubarsky and Krasnow 2003; Andrew and Ewald 2010). The role of cell death in SGs, however, has recently been challenged, with lumen formation occurring after apoptosis is blocked (Nedvetsky et al. 2014).

As previously described, SG development is generally classified into prebud, initial bud, pseudoglandular, canalicular, and terminal bud stages, with gland initiation occurring around embryonic day 11 (E11) in the mouse (Jaskoll and Melnick 1999). The prebud stage is characterized as a thickening of the oral epithelium, which proliferates toward the underlying mesenchyme and forms an epithelial bud with a narrow stalk region (initial bud stage). The bud then undergoes clefting to create multiple buds that characterize the pseudoglandular stage. The epithelial stalks then undergo canalization, while ductal and acinar cells then differentiate to achieve a mature gland (Jaskoll and Melnick 1999). This pattern of development is very similar to the stages observed during human development (Lourenço et al. 2008; Teshima et al. 2011).
To date, lumen formation in SGs has been reported to start from E14.5 (Jaskoll et al. 2001; Tucker 2007). Apoptotic cells have been observed localized in the developing ducts, and active caspase 3, a central mediator of the apoptotic pathway, is expressed in these regions (Jaskoll and Melnick 1999; Jaskoll et al. 2001). In keeping with an active role of apoptosis in lumen formation, Survivin - a member of the inhibitors of apoptosis protein family - is expressed in the nucleus of epithelial cells bordering the forming lumina as the canals start to form (Jaskoll et al. 2001).

Programmed cell death can be triggered by different molecular pathways. The extrinsic pathway involves apoptotic signaling from outside the cell, mediated by members of the tumor necrosis factor receptor superfamily (Elmore 2007). The intrinsic pathway depends on endogenous factors to activate apoptosis and is stimulated by intracellular stress, such as DNA damage, hypoxia, oncogene activation, and deprivation of growth factors. The mitochondria is the central organelle of

\footnotetext{
'Department of Stomatology, School of Dentistry, University of Sao Paulo, São Paulo, Brazil

${ }^{2}$ Department of Craniofacial Development and Stem Cell Biology, King's College London, London, UK
}

A supplemental appendix to this article is published electronically only at http://jdr.sagepub.com/supplemental.

\section{Corresponding Author:}

A.S. Tucker, Department of Craniofacial Development and Stem Cell Biology, King's College London, London, SEI 9RT, UK.

Email: abigail.tucker@kcl.ac.uk 
this pathway and releases several proapoptotic molecules into the cytoplasm (Elmore 2007; Taylor et al. 2008).

Given the specific functions of the SG ductal system to properly secrete and deliver saliva in the oral cavity, it is important to understand the mechanisms involved in SG formation. In other systems, cell polarization, apoptosis, anoikis, and cord hollowing have been suggested to play a role in epithelial tubulogenesis (Debnath et al. 2002; Mailleux et al. 2007; Andrew and Ewald 2010; Nedvetsky et al. 2014). Here, we have concentrated on the role of apoptosis, analyzing the temporal expression of apoptotic markers during early SG development and using inhibition of apoptosis in culture, thereby introducing a potential early role of caspase-dependent apoptosis in lumen formation starting prior to branching morphogenesis.

\section{Material and Methods}

\section{Organ Culture}

Mouse tissue was collected from wild-type CD1 animals housed in the Biological Services Unit in New Hunts House at King's College London in approved nonspecific-pathogen-free conditions. Mice were culled via schedule 1 culling methods, as approved by the Home Office and King's College London. Animal experiments conform to ARRIVE (Animal Research: Reporting of In Vivo Experiments) guidelines. Embryonic SGs at stages E12.5 to E14.5 were dissected out for cultures and immunohistochemistry analysis ( $n=6$ of each stage and group).

Pan-caspase inhibitor Z-VAD-FMK (G7231, Promega, Madison, WI, USA) was used for in vitro apoptotic inhibition at a range of concentrations $(100,150,200 \mu \mathrm{M})$ at $\mathrm{E} 13.5$ and $\mathrm{E} 14.5(n=9)$ and at $100 \mu \mathrm{M}$ at E12.5 $(n=18)$. Samples were placed on permeable membranes (BD, Franklin Lakes, NJ, USA) over culture medium (Advanced Dulbecco Modified Eagle Medium F12, Invitrogen, Waltham, MA, USA; $1 \%$ GlutaMAX, Invitrogen; $1 \%$ penicillin-streptomycin) at $37{ }^{\circ} \mathrm{C}$ and $5 \% \mathrm{CO}_{2}$. Controls were cultured in dimethyl sulfoxide (DMSO) at the same concentration. In situ CaspACE FITC-ZVAD-FMK marker (G7461, Promega) was added to the culture medium in the last day for $3 \mathrm{~h}$. Cultured SGs were then fixed for $30 \mathrm{~min}$ at room temperature and washed in phosphate-buffered saline (PBS).

LysoTracker RED (DND-99, Invitrogen) was added in culture medium $(5 \mu \mathrm{M})$ of live SGs $(n=6$ of each stage) for $3 \mathrm{~h}$. After washing with fresh culture medium and PBS Triton $0.1 \%$, samples were fixed in $4 \%$ paraformaldehyde for $30 \mathrm{~min}$ at room temperature. Samples were permeabilized with PBS Triton $0.1 \%$ for $15 \mathrm{~min}$, followed by incubation in blocking solution for $2 \mathrm{~h}$ and DAPI $(1: 1,000$; Invitrogen) for $4 \mathrm{~h}$ at room temperature. For immunohistochemistry/immunofluorescence and morphometric analysis, see the Appendix Methods.

\section{Results}

Previous papers have concentrated on apoptosis during duct cavitation from E14.5 onward; we therefore wanted to analyze whether apoptosis also had a role during earlier stages of gland development, when the main stalk of the gland is formed. Morphologic analysis of early stages is shown in Fig. 1 (A, E, I), and the epithelial structures of forming SGs are highlighted with E-cadherin staining (Fig. 1B, F, J). The opening of the first lumenal space appears from E13.5 (Fig. 1E, arrow). Specific apoptotic activity was confirmed with cleaved caspase 3 and terminal deoxynucleotidyl transferase dUTP nick end labeling (TUNEL) at the same stages (Fig. 1C, G, K and 1D, H, L, respectively; Appendix Fig. 1). Both markers were found in the center of the main epithelial stalk at E12.5 where the lumen space is due to form (Fig. 1C, D). High levels of apoptotic cells were observed at E13.5 within the main duct and the oral epithelium (Fig. 1G, H; Appendix Fig. 1). Interestingly, sparse (Fig. 1K, arrow) or no positive cells (Fig. $1 \mathrm{~L}$, arrowheads) were observed in the more developed ducts at E14.5. At E12.5, subtle luminal gaps were observed within the main stalk (Fig. 1M, arrowheads), and at E13.5 they were clear within the duct associated with dying cells (Fig. 10, arrowheads). In contrast, the duct closer to the branching region had not yet initiated lumen formation. At these early stages, dying cells were found in the center of the main epithelial stalk via LysoTracker staining, which labels lysozymes (Fig. 1N, P, arrows; Fogel et al. 2012). Colocalization of LysoTracker and cleaved caspase 3 expression was observed in the duct of the submandibular gland at E13.5 (Fig. 1Q-T). In the sublingual gland, which is delayed in development compared with the neighboring submandibular (Redman and Ball 1978), cleaved caspase 3-positive cells were observed running along the forming duct, while LysoTracker was not yet expressed (Fig. $1 \mathrm{Q}, \mathrm{R})$, confirming that presence of cleaved caspase 3 is an early indicator of lumenal space opening.

To confirm the presence of the forming lumen, cytokeratin 7 (K7) was used to identify the presumptive luminal areas within the ducts as previously reported in developing SGs (Walker et al. 2008) and also in less differentiated cells of the ductal tree in the mammalian pancreas (Bouwens 1998) (Fig. 2). At E12.5, K7 expression was observed in the central cells of the epithelial stalk connected to the single bud (Fig. 2A, arrows), while expression was completely absent in the bud itself (Fig. 2A, arrowhead). At E13.5, a stronger expression was observed in the luminal cells of the main duct, lining the developing gaps (Fig. 2B, arrow). Toward the canalization stage at E14.5, the expression of $\mathrm{K} 7$ remained positive in the center of the ductal structures where clear lumens were developing (Fig. 2C, arrows). During these stages, $\mathrm{K} 7$ expression was also observed in the oral epithelium, with expression increasing at a later stage (E14.5; Fig. 2D, arrow).

The role of apoptosis in the main stalk was analyzed by in vitro culture to block apoptosis via a pan-caspase inhibitor at $100 \mu \mathrm{M}$ in the developing glands. Caspases are the main effectors and activators of the intrinsic and extrinsic apoptotic pathways (Degterev et al. 2003; Taylor et al. 2008). SG explants at E12.5 were cultured for $72 \mathrm{~h}$. During this period, the wild-type cultures developed from a budlike thickening to a main bud that had started to cleft, attached to the oral epithelium by a 
narrow stalk. In contrast, the stalk region failed to narrow in the caspasetreated explants (Fig. 3A, arrows). The diameter of the main primary stalk of each gland was measured in both experimental and control groups at the start and during culture, resulting in statistically significant difference from 24 h (Fig. 3B; $P<0.05, n=18$ ). E12.5 cultures developed much slower than those without DMSO, the carrier used, indicating that this early stage is sensitive to even fairly low levels of this vehicle. In agreement with this, a higher concentration of inhibitor and, therefore, carrier led to arrest of gland development (data not shown). We subsequently performed a similar functional experiment using E13.5 and E14.5 SGs to assess the effects of pancaspase inhibition on duct development at later stages. For this, we used the concentrations of $100 \mu \mathrm{M}$ plus $150 \mu \mathrm{M}$ and $200 \mu \mathrm{M}$. At E13.5, the addition of $150 \mu \mathrm{M}$ and $200 \mu \mathrm{M}$ inhibitor led to complete loss of apoptotic cells, as determined by activated caspase 3 staining, after $20 \mathrm{~h}$ in culture; yet at $100 \mu \mathrm{M}$, a few positive cells were observed, indicating that some cells had escaped inhibition at this concentration at this stage (Fig. 4A, arrows; $n=$ 3 each concentration). At E13.5 addition of Z-VAD-FMK inhibitor resulted in wider stalks in a dose-dependent manner (Fig. 4B). At $150 \mu \mathrm{M}$, statistically significant wider stalks were observed after $72 \mathrm{~h}$ in culture (Fig. $4 C)$. The wide morphology of the ductal structures after treatment agrees with the data from E12.5, suggesting that caspase-dependent apoptosis plays a role in the narrowing of the ducts prior to lumen formation. At E13.5, branching was also impaired showing reduction in the number of buds when cultured at higher concentrations of inhibitor (Fig. 4D, Fig. 5A-F). In contrast, E14.5 SG cultures showed no abnormality within all groups (Appendix Fig. 2), agreeing with the fact that only low levels of apoptosis are evident at this stage (see Fig. 1).

To label cells that had been blocked by the inhibitor, plus cells that were undergoing cell death just before fixation, the apoptotic inhibitor marker FITC-Z-VAD-FMK was added to

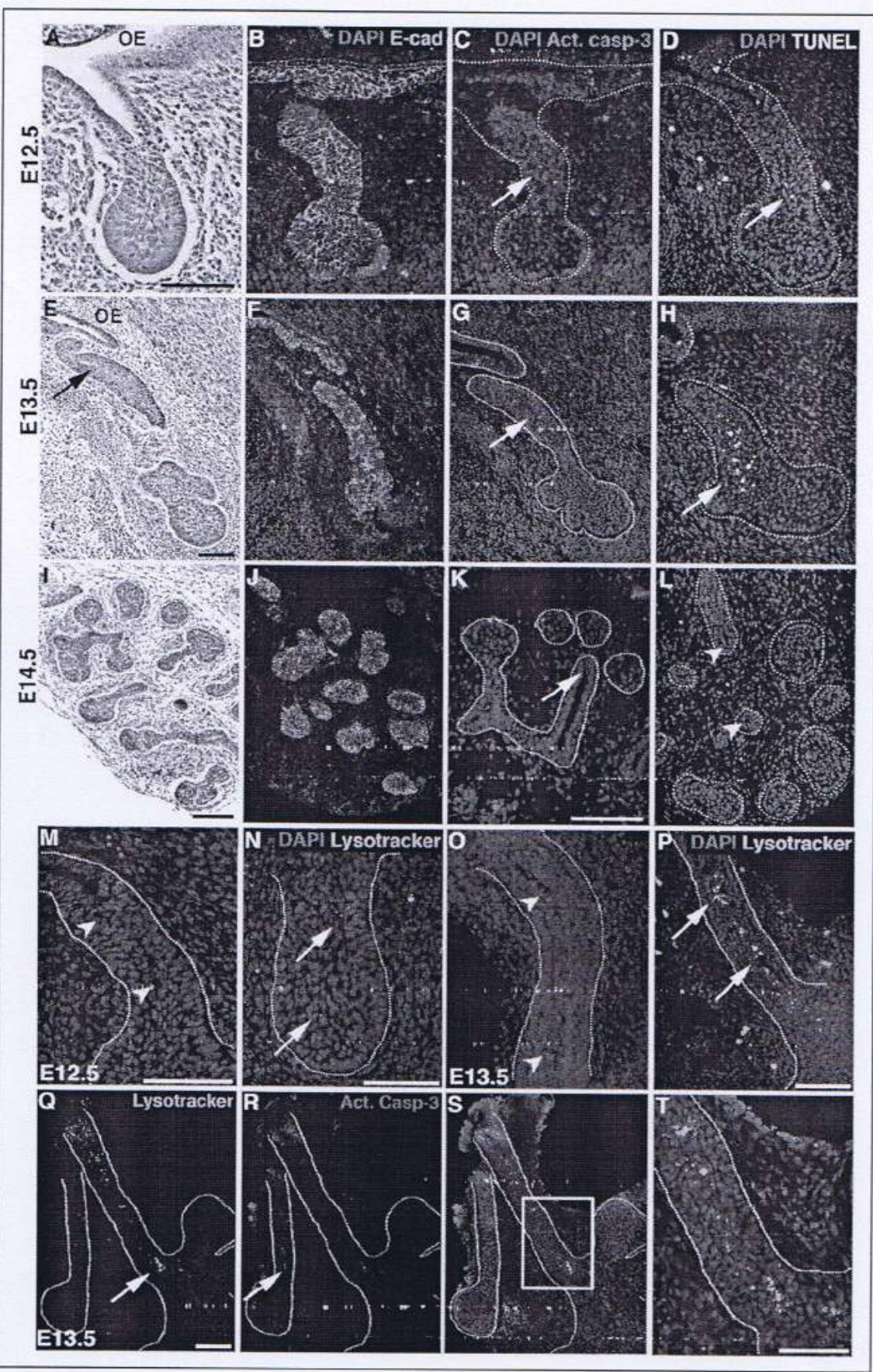

Figure I. Cell death in early salivary gland (SG) development. (A-D) embryonic day I 2.5 (E|2.5), (E-H) E13.5, (I-L) El4.5, (M-P) main duct of submandibular gland, (Q-T) EI3.5 SG. (A, E, I) Histology sagittal sections of EI 2.5 to EI4.5 SG. (B, F, J) E-cadherin expression in developing SG epithelium. (C, G, K, R) Activated caspase 3. (D, H, L) TUNEL. (M, O) DAPI staining with characteristic apoptotic condensed nuclei visible in the central lumen area (arrowheads). (N, P, Q) LysoTracker pseudocolored green from red. At EI2.5, the first signs of apoptosis are visible, as shown by all 3 markers (C, D, N, arrows), with a higher number at EI 3.5 as the gland starts to branch (G, H, P, arrows). At El 4.5, scarce or no positive cells are present in the lumen spaces within the ducts $(K, L)$. Arrows indicate positive cells; arrowheads indicate forming lumens. OE, oral epithelium. (Q-T) Comparison between LysoTracker and cleaved caspase 3 expression ( $Q, R$, arrows) localization in the same EI3.5 SG sample. Cleaved caspase 3-positive cells are present mainly within the duct of the sublingual gland (arrow), to the left of the larger submandibular gland. LysoTracker is mainly visualized in submandibular ductal cells (arrow). High magnification of the main duct in the submandibular gland showing both LysoTracker and cleaved caspase 3 expression panel T. Scale bar $=100 \mu \mathrm{m}$. 

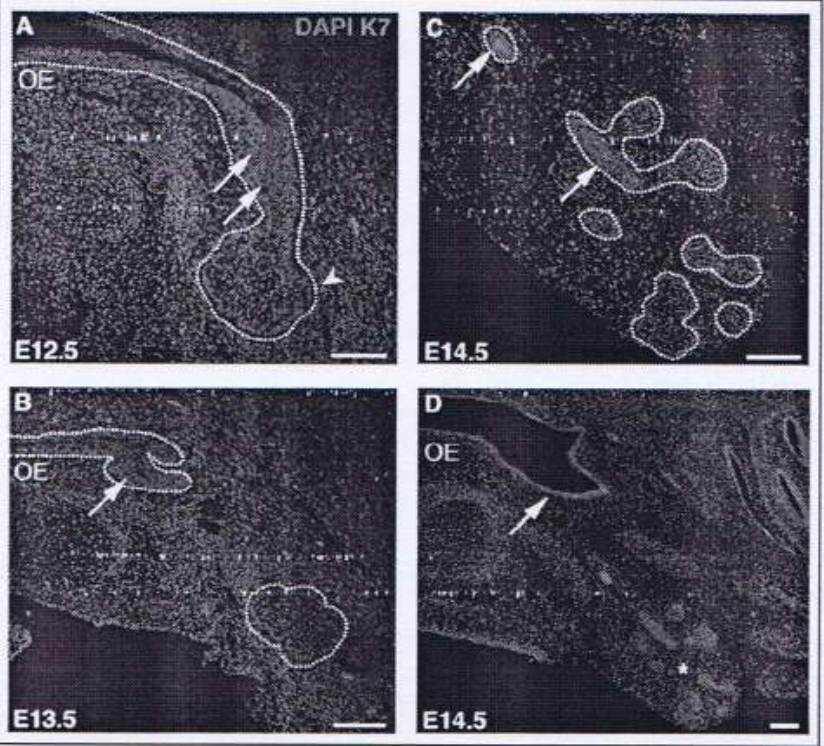

Figure 2. Presumptive lumen formation as labeled by cytokeratin 7 (K7). (A) K7-positive cells are localized at the center of the initial solid stalk at embryonic day 12.5 (EI 2.5) (arrows), while K7 is completely absent in bud areas (arrowhead). (B) K7 remains expressed at EI 3.5 restricted to the presumptive luminal area (arrow). (C) At E14.5, K7 is more evident within the lumen space of salivary gland ducts. (D) K7 is also expressed in the oral epithelium. Asterisk marks submandibular gland. OE, oral epithelium. Scale bar $=100 \mu \mathrm{m}$.

E13.5 cultures at $72 \mathrm{~h}\left(n=9\right.$; Fig. $\left.5 \mathrm{~A}^{\prime}-\mathrm{F}^{\prime}\right)$. No labeling was observed in the SG epithelium of the control cultures, indicating low levels of apoptosis at this stage of development (Fig. $5 \mathrm{~A}^{\prime}, \mathrm{C}^{\prime}, \mathrm{E}^{\prime}$ ), agreeing with the findings from Figure 1G, J. A few positive cells were evident in the mesenchyme, increasing with higher concentration of DMSO, indicating some cell death in the mesenchyme at the end of the culture period. This again highlights the toxicity of DMSO for developing SGs and the need to be careful when analyzing results when using higher concentrations. In the inhibitor-treated cultures, large numbers of positive cells were concentrated at the center of the main ducts, corresponding to the pattern of apoptosis observed in glands in vitro at the start of culture (Fig. 5B', $\mathrm{D}^{\prime}, \mathrm{F}^{\prime}$ compared with Fig. 1). In addition to the effect on width of the duct, lumen formation appeared abnormal. In the controls at $100 \mu \mathrm{M}$ and $150 \mu \mathrm{M}$, clear, cell-free lumens formed in the central stalk (Fig. $\left.5 \mathrm{~A}, \mathrm{~A}^{\prime}, \mathrm{B}, \mathrm{B}^{\prime}\right)$. In contrast, this region in the caspase inhibitor cultures was filled with fluorescein isothiocyanate (FITC) labeled cells (Fig. 5D). In section, the lack of lumen was clear in the inhibitor-treated cultures (Appendix Fig. 1). In addition to defects in duct morphogenesis, E13.5 samples showed a dose-dependent defect in branching morphogenesis (Fig. 5). The reduced branching was not expected, as very few apoptotic cells were associated with this part of the gland at these stages; however, the FITC marker also showed high levels of inhibitor binding in the mesenchyme, particularly at high concentrations (Fig. 5D', $\mathrm{F}^{\prime}$ ), suggesting that the inhibitor may also have had an impact on normal development of the mesenchyme, therefore indirectly affecting branching morphogenesis.

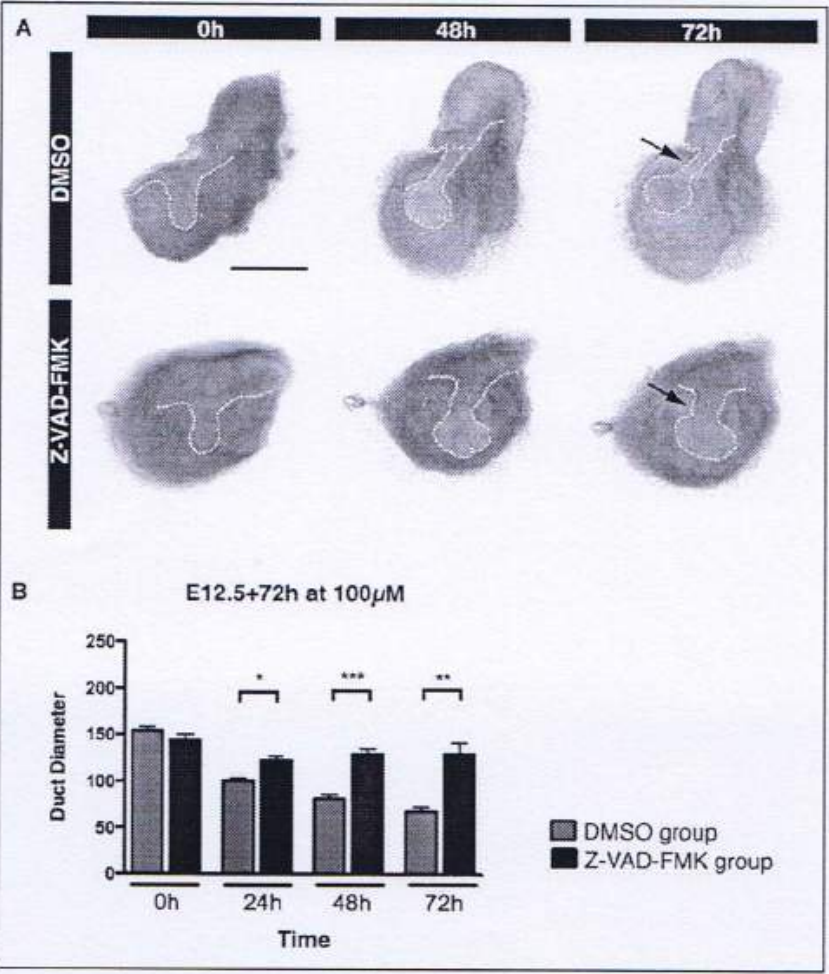

Figure 3. Early inhibition of caspases leads to defects in duct morphology. (A) Embryonic day 12.5 (EI2.5) salivary gland explants cultured for $72 \mathrm{~h}$. A defect in duct morphology is evident between the control (DMSO) and the experimental (ZVAD) group after 48 and 72 $\mathrm{h}$ of culture. Arrows indicate the ducts at $72 \mathrm{~h}$. Scale bar $=500 \mu \mathrm{m}$. (B) Paired Student's t-test statistical analysis of the duct diameter of both groups of E12.5 salivary gland cultures. No difference in duct dimensions was observed prior to culture at $\mathrm{O}$ h, as compared with statistically significant narrowing of the ducts in control versus treated cultures after 24. 48 , and 72 h. $n=18$ for $E \mid 2.5$ and $n=9$ for $E \mid 3.5$ and $E \mid 4.5$ giands. $* p=0.02$. ${ }^{* k} p=0.008$. $* * * p=0.0006$. Error bars represent $\mid$ standard error of the mean.

\section{Discussion}

Apoptosis has been recognized as one of the most important mechanisms involved in developmental dynamics (Flusberg and Sorger 2015) with the large caspases being key regulators of the main programmed cell death pathways (Hengartner 2000; Degterev et al. 2003; Taylor et al. 2008; Kuranaga 2011). Branching morphogenesis regulates the formation of distinct organs such as lungs, kidney, and mammary and salivary glands, which can perform essential physiologic functions, such as exchanging gases or production of secretions (Patel et al. 2006; Larsen et al. 2010; Ochoa-Espinosa and Affolter 2012; Patel and Hoffman 2014). Studies on epithelial tube morphogenesis have highlighted the involvement of distinct methods for lumen formation depending on the type of organ involved (Lubarsky and Krasnow 2003; Chung and Andrew 2008; Andrew and Ewald 2010). In SGs, it has been suggested that the central cells of the epithelial stalks undergo apoptosis in a process known as cavitation, clearing the luminal space during embryonic SG development (Tucker 2007; Wells and Patel 
2010). Corroborating these previous reports, our findings illustrate the presence of dying cells in the center of the presumptive ducts, as shown by LysoTracker staining, activated caspase 3, and TUNEL. Temporal expression of apoptotic cells in duct formation, however, diverged from previous studies. To date, it has been reported that mouse SG lumen spaces start opening only from stage E14.5 or E15.5, with apoptotic cells and cleaved caspase 3 observed from E14.5 (Jaskoll and Melnick 1999; Melnick et al. 2001). It is therefore assumed that SGs are composed of solid and nonluminized cords before this time point (Jaskoll et al. 2001; Larsen et al. 2006; Tucker 2007). In this study, apoptotic cells were detected at earlier stages, from E12.5, suggesting an important early role for apoptosis in the formation of the lumen of the central SG ducts; the central duct was also shown to open at early stages of development, before the rest of the gland had undergone branching morphogenesis. This finding was further supported by the expression of K7 in the center of the main stalk of developing SGs from E12.5 (Walker et al. 2008). Such discrepancy could be due to the fact that earlier stages were not studied in details or that different methods for detecting apoptosis were employed. Jaskoll and Melnick (1999) reported the presence of apoptotic cells only from E14.5 using the Apostain assay, which identifies DNA after caspase cleavage and before DNA fragmentation. Comparison between TUNEL and Apostain assays have reported good reliability of both techniques, although their outcomes showed slight variations in the timing and amount of expression (Prochazkova et al. 2003). Our results revealed scarce/occasional apoptotic cells (cleaved caspase 3 and TUNEL positives) at later stages, E14.5 and E15.5, and no overt defect in gland development in cultures treated with inhibitor from E14.5, indicating a more minor role for apoptosis at these later time points.

Functional experiments were performed to assess the effects of suppressing apoptotic activity in SG development through in vitro pan-caspase inhibition. The Z-VAD-FMK inhibitor binds irreversibly to active caspases, and from the lowest concentration of $100 \mu \mathrm{M}$ it was able to compromise SG development at early stages. In previous studies using epithelial cell cultures, apoptotic
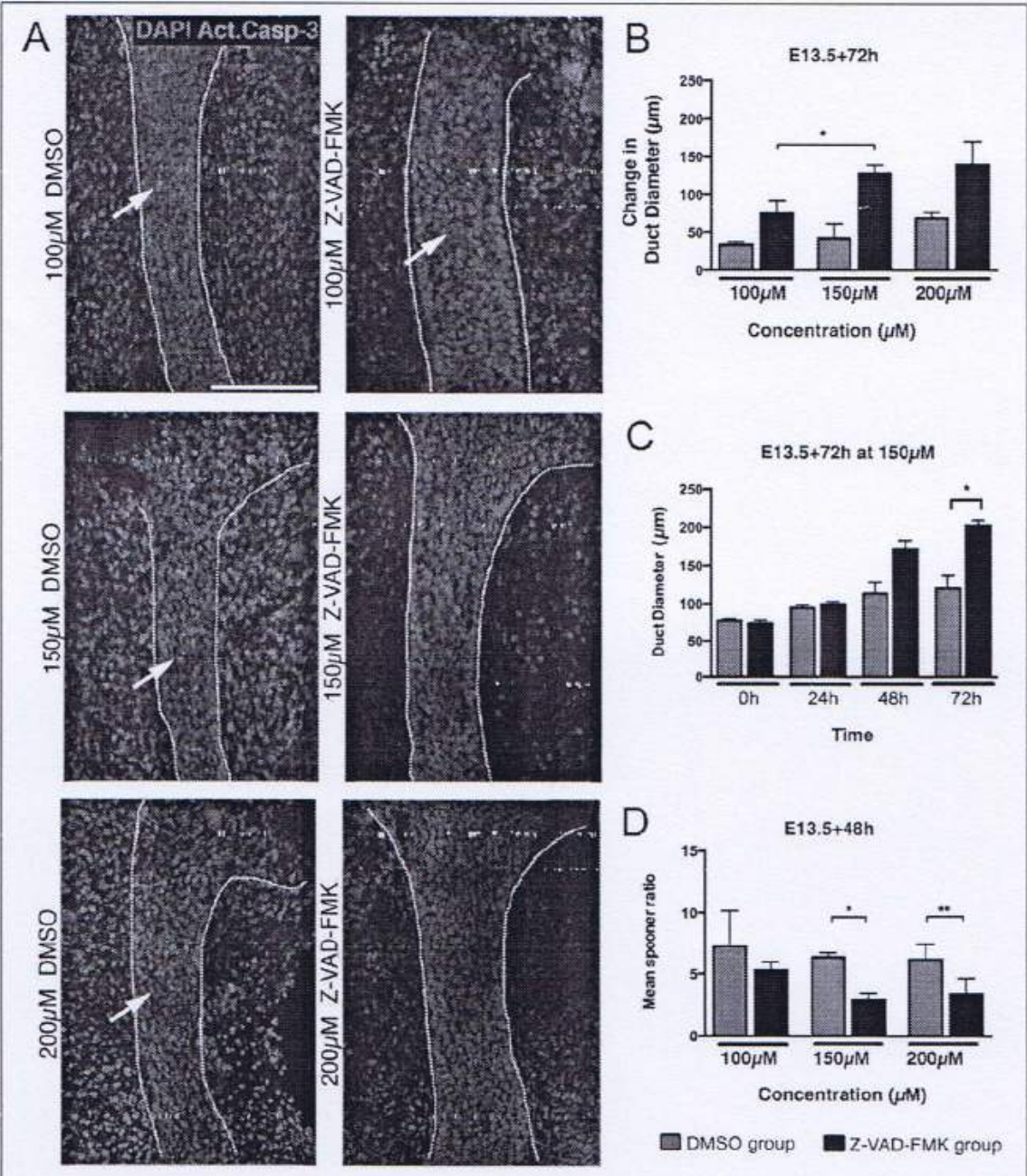

Figure 4. Loss of activated caspase 3 leads to a widening of the ducts and a reduction in branching at the pseudoglandular stage. (A) Expression of cleaved caspase 3 within developing submandibular ducts of treated and nontreated embryonic day 13.5 (EI3.5) salivary gland (SG) cultures after $20 \mathrm{~h}$ (arrows). High levels of cleaved caspase 3-positive cells (red) were found within developing lumen space of all controls (left column). From $150 \mu$ M of Z-VAD-FMK, cleaved caspase 3 was completely absent, with a few labeled cells present at $100 \mu M$ (right column). Scale bar $=100 \mu \mathrm{m}$. (B) Unpaired the 3 Z-VAD-FMK concentrations. $n=9$, *P $<0.05$. (C) Paired Student's t-test statistical analysis of the final duct diameter of both groups in EI 3.5 SG cultures. No difference in duct dimensions was observed prior to culture at $\mathrm{Oh}$, as compared with statistically significant changes in duct width in control versus treated cultures after 24,48 , and 72 h. $n=18, * p=0.03$. (D) Mean Spooner ratio for treated (Z-VAD-FMK) and nontreated groups (DMSO) after $48 \mathrm{~h}$. Paired Student's $t$ test shows a significant decrease in branching using 150 and $200 \mu \mathrm{M}$ of inhibitor. $n=9, * p=0.01, * * p=0.006$.

inhibition was sufficient to avoid lumen formation when cell polarization was not enhanced (Martín-Belmonte et al. 2008). However, when cell polarization was stimulated in prostate epithelial models, inhibition of apoptosis only delayed lumen formation (Pearson et al. 2009). Studies with mammary cell cultures have also shown similar results by inhibiting apoptosis, correlating apoptosis with generation and maintenance of hollow lumen spaces (Debnath et al. 2002).

Defects in branching and duct formation due to pan-caspase inhibition reveal an important function of apoptosis during SG development. However, it is worth bearing in mind that caspase 


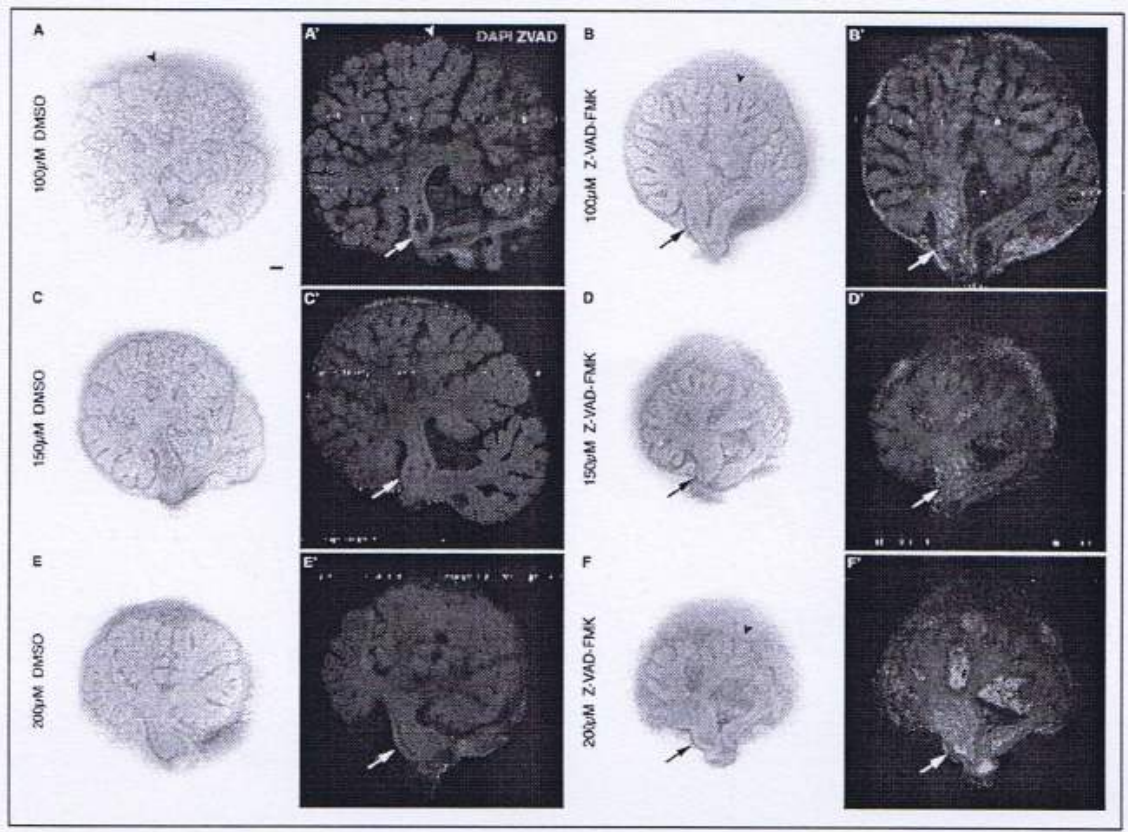

Figure 5. Inhibition of caspases at embryonic day 13.5 (EI3.5) leads to loss of lumen formation in the main stalk. Explants cultured from EI 3.5 for $72 \mathrm{~h}$, with or without Z-VAD.FMK inhibitor. FITC-Z-VAD-FMK added to all cultures prior to fixation to label cells that are currently undergoing apoptosis (control and treated groups; $\mathbf{A}^{\prime}-\mathbf{F}^{\prime}$ ) and caspase positive cells that have been inhibited from undergoing apoptosis (treated group) $\left(B^{\prime}, D^{\prime}, F^{\prime}\right)$. (A, C, E) Morphologic images of control explants (DMSO treated). Arrowheads indicate areas of branching morphogenesis. $\left(A^{\prime}, C^{\prime}, E^{\prime}\right)$ Confocal images of the same control group highlighting absence of apoptosis at this stage inside the main ducts (arrows) when treated with FITC-Z-VAD-FMK before fixation. (E) Some apoptosis (green label) is evident in the mesenchyme at high levels of DMSO. (B, D, F) Pan-caspase inhibition at a range of concentrations, demonstrating defects in branching morphogenesis (arrowheads) and expansion of the duct diameter (arrows) in the absence of caspases. ( $B^{\prime}, D^{\prime}, F^{\prime}$ ) Confocal images of the same treated group highlighting presence of cells that were inhibited from undergoing apoptosis (green-labeled cells) inside the main ducts (arrows). The main ducts are filled with cells rather than having a cell-free lumen, as seen in controls. High levels of apoptosis (green label) are observed in the mesenchyme. Scale bar $=500 \mu \mathrm{m}$.

inhibition can trigger the activation of non-caspase-dependent cell death pathways, such as necrosis and autophagy, which could compensate for the absence of apoptosis (Vandenabeele et al. 2006). Additionally, it has been reported that caspase functions are not exclusively apoptotic, being also correlated to dynamic cell processes such as cell fate determination, compensatory proliferation of neighboring cells, and actin cytoskeleton reorganization, in a nonapoptotic context during mouse development (Wang and Lenardo 2000; Kuranaga 2011). Caspase inhibition can therefore potentially affect other essential mechanisms during embryogenesis, which might have resulted in the severe phenotypes observed in our in vitro cultures not only in duct formation but also in epithelial branching. The importance of apoptosis during organ development was recently correlated to effects on proliferation, movement, and shape of neighboring cells (Pérez-Garijo and Steller 2015), suggesting an additional function for those apoptotic cells during early SG development.

Studies analyzing epithelial cell interactions during SG development have shown links between control of lumen formation and cell polarization (Cutler and Mooradian 1987; Andrew and Ewald 2010), supported more recently by genetic links between the 2 processes (Nedvetsky et al. 2014). Neuronalderived vasoactive intestinal peptide (VIP) was found as an important regulator of key steps during epithelial tubulogenesis in SG development, where exogenous VIP stimulated the formation of a single contiguous lumen space, as marked by apical atypical protein kinase $\mathrm{C}$ (aPKC) and subapical GM130, from E13. Moreover, it was reported that VIP-induced lumen formation did not require apoptosis, showing normal lumen formation in SGs cultured with pan-caspase inhibitor. In this experiment, the inhibitor was used at $50 \mu \mathrm{M}$, whereas we saw only partial inhibition using a higher concentration of $100 \mu \mathrm{M}$; as such, the lack of phenotype in the Nedvetsky paper could therefore be due to the low dose of Z-VAD-FMK used. Normal lumens were also observed in Bax-knockout mice; however, they were analyzed only at E17. In this case, it is possible that Bax-dependent lumen formation was compensated for by other cell death mechanisms or analogous molecules. This protein is required only for intrinsic apoptosis, and it shares similar proapoptotic function with another apoptotic protein, Bak (Lindsten et al. 2000; Karbowski et al. 2006). Compensation by other cell death pathways is a common mechanism observed in other areas where cell death has been investigated, for example, in the limb (Miura 2012; Suzanne and Steller 2013).

A cell mechanism named anoikis has also been indicated as an important process during epithelial tube formation, as seen in mammary gland morphogenesis (Debnath et al. 2002; Mailleux et al. 2007). This is based on the loss of cell anchorage, which disturbs cell-cell and cell-extracellular matrix adhesion interactions, playing important role in the physiologic induction of apoptosis during development and pathogenesis, mainly regarding metastatic transformation (Grossmann 2002). Corroborating this hypothesis, in our SG explant cultures, the apoptotic inhibition marker FITC-Z-VAD-FMK indicated the presence of many unorganized cells remaining in the center of the presumptive duct, not showing a clear lumen space, and being detached from the polarized epithelial cells lining the cavity. Given that anoikis is also potentially responsible for triggering apoptosis during lumen space opening, cavitation could actually represent a special case of cord hollowing, which requires cell polarization and the extra step of clearing the lumen (Andrew and Ewald 2010).

In conclusion, initial lumen formation in the SG main stalk seems to occur by an apoptosis-driven mechanism. The 
decreasing expression of apoptotic cells through SG development either in ducts or acini suggests that further lumen formation and maintenance of the subsequent ducts possibly use other mechanisms. Cell polarization, anoikis, and nonapoptotic cell death pathways may be essential to these developmental processes. It will therefore be important to further explore these ideas to establish a definite causal relationship among lumen formation, lumen maintenance, and cell death.

\section{Author Contributions}

T.H.N. Teshima, contributed to conception, design, data acquisition, analysis, and interpretation, drafted and critically revised the manuscript; K.L. Wells, contributed to conception, design, and data acquisition, drafted the manuscript; S.V. Lourenço, contributed to data interpretation, critically revised the manuscript; A.S. Tucker, contributed to conception, design, data acquisition, analysis, and interpretation, critically revised the manuscript. All authors gave final approval and agree to be accountable for all aspects of the work.

\section{Acknowledgments}

T.H.N. Teshima and S.V. Lourenço were funded by Conselho Nacional de Desenvolvimento Científico e Tecnológico (grant 245882/2012-0) and by Fundação de Amparo à Pesquisa do Estado de São Paulo (grant 2011/18865-2). A.S. Tucker and K.L. Wells were funded by the Medical Research Council. We thank Dr. Marcia Gaete and Dr. Neal Anthwal for assisting in collecting data and laboratory guidance. The authors declare no potential conflicts of interest with respect to the authorship and/or publication of this article.

\section{References}

Andrew DJ, Ewald AJ. 2010. Morphogenesis of epithelial tubes: Insights into tube formation, elongation, and elaboration. Dev Biol. 341(1):34-55.

Bouwens L. 1998. Cytokeratins and cell differentiation in the pancreas. J Pathol. 184(3):234-239.

Chung S, Andrew DJ. 2008. The formation of epithelial tubes. J Cell Sci. 121:3501-3504.

Cutler LS, Mooradian BA. 1987. Lumen formation during development of the rat submandibular gland. J Dent Res. 66(10):1559-1162.

Debnath J, Mills KR, Collins NL, Reginato MJ, Muthuswamy SK, Brugge JS. 2002. The role of apoptosis in creating and maintaining luminal space within normal and oncogene-expressing mammary acini. Cell. 111(1):29-40.

Degterev A, Boyce M, Yuan J. 2003. A decade of caspases. Oncogene. 22(53):8543-8567.

Elmore S. 2007. Apoptosis: a review of programmed cell death. Toxicol Pathol. $35(4): 495-516$.

Fogel JL, Thein TZ, Mariani FV. 2012. Use of LysoTracker to detect programmed cell death in embryos and differentiating embryonic stem cells. $\mathrm{J}$ Vis Exp. 2012;68:4254.

Flusberg DA, Sorger PK. 2015. Surviving apoptosis: life-death signaling in single cells. Trends Cell Biol. 25(8):446-458.

Grossmann J. 2002. Molecular mechanisms of "detachment-induced apoptosis—anoikis." Apoptosis. 7(3):247-260.

Hengartner MO. 2000. The biochemistry of apoptosis. Nature. 407(6805):770 -776.

Jaskoll T, Chen H, Min Zhou Y, Wu D, Melnick M. 2001. Developmental expression of survivin during embryonic submandibular salivary gland development. BMC Dev Biol. 1:5.

Jaskoll T, Melnick M. 1999. Submandibular gland morphogenesis: stage-specific expression of TGF-alpha/EGF, IGF, TGF-beta, TNF, and IL-6 signal transduction in normal embryonic mice and the phenotypic effects of TGFbeta2, TGF-beta3, and EGF-r null mutations. Anat Rec. 256(3):252-268.
Karbowski M, Norris KL, Cleland MM, Jeong SY, Youle RJ. 2006. Role of Bax and Bak in mitochondrial morphogenesis. Nature. 443(7112):658-662. Kuranaga E. 2011. Caspase signaling in animal development. Dev Growth Differ. 53(2):137-148.

Kwon HR, Larsen M. 2015. The contribution of specific cell subpopulations to submandibular salivary gland branching morphogenesis. Curr Opin Genet Dev. 32:47-54.

Larsen M, Wei C, Yamada KM. 2006. Cell and fibronectin dynamics during branching morphogenesis. J Cell Sci. 119(Pt 16):3376-3384

Larsen M, Yamada KM, Musselmann K. 2010. Systems analysis of salivary gland development and disease. Wiley Interdiscip Rev Syst Biol Med. 2(6):670-682.

Lindsten T, Ross AJ, King A, Zong WX, Rathmell JC, Shiels HA, Ulrich E, Waymire KG, Mahar P, Frauwirth K, et al. 2000. The combined functions of proapoptotic Bcl-2 family members Bak and Bax are essential for normal development of multiple tissues. Mol Cell. 6(6):1389-1399.

Lourenço SV, Uyekita SH, Lima DMC. Soares FA. 2008. Developing human minor salivary glands: morphological parallel relation between the expression of TGF-beta isoforms and cytoskeletal markers of glandular maturation. Virchows Arch. 452(4):427-434

Lubarsky B, Krasnow MA. 2003. Tube morphogenesis: making and shaping biological tubes. Cell. 112(1):19-28.

Mailleux AA, Overholtzer M, Schmelzle T, Bouillet P, Strasser A, Brugge JS. 2007. BIM regulates apoptosis during mammary ductal morphogenesis, and its absence reveals alternative cell death mechanisms. Dev Cell. 12(2):221-234.

Martin-Belmonte F, Yu W, Rodriguez-Fraticelli AE, Ewald AJ, Werb Z, Alonso MA, Mostov K. 2008. Cell-polarity dynamics controls the mechanism of lumen formation in epithelial morphogenesis. Curr Biol. 18(13):507-513.

Melnick M, Chen H, Zhou Y, Jaskoll T. 2001. Embryonic mouse submandibular salivary gland morphogenesis and the TNF/TNF-R1 signal transduction pathway. Anat Rec. 262(3):318-330.

Miura M. 2012. Apoptotic and nonapoptotic caspase functions in animal development. Cold Spring Harb Perspect Biol. 4(10):a008664.

Nedvetsky P, Emmerson E, Finley JK, Ettinger A, Cruz-Pacheco N, Prochazka J, Haddox CL, Northrup E, Hodges C, Mostov KE, et al. 2014. Parasympathetic innervation regulates tubulogenesis in the developing salivary gland. Dev Cell. 30(4):449-462.

Ochoa-Espinosa A, Affolter M. 2012. Branching morphogenesis: from cells to organs and back. Cold Spring Harb Perspect Biol. 4:a008243.

Patel VN, Hoffman MP. 2014. Salivary gland development: a template for regeneration. Semin Cell Dev Biol. 25-26:52-60.

Patel VN, Rebustini IT, Hoffman MP. 2006. Salivary gland branching morphogenesis. Differentiation. 74(7):349-364.

Pearson JF, Hughes S, Chambers K. Lang SH. 2009. Polarized fluid movement and not cell death, creates luminal spaces in adult prostate epithelium. Cell Death Differ. 16(3): $475-482$.

Pérez-Garijo A, Steller H. 2015. Spreading the word: non-autonomous effects of apoptosis during development, regeneration and disease. Development. 142(19):3253-3262.

Prochazkova J, Kylarova D, Vranka P. Lichnovsky V. 2003. Comparative study of apoptosis-detecting techniques: TUNEL, apostain, and lamin B. Biotechniques. 35(3):528-534.

Redman RS, Ball WD. 1978. Cytodifferentiation of secretory cells in the sublingual gland of the prenatal rat: a histological, histochemical and ultrastructural study. Am J Anat. 153(3):367-389.

Suzanne M, Steller H. 2013. Shaping organisms with apoptosis. Cell Death Differ. 20(5):669-675.

Taylor RC, Cullen SP, Martin SJ. 2008. Apoptosis: controlled demolition at the cellular level. Nat Rev Mol Cell Biol. 9(3):231-241.

Teshima TH, Ianez RF, Coutinho-Camillo CM, Buim ME, Soares FA, Lourenço SV. 2011. Development of human minor salivary glands: expression of mucins according to stage of morphogenesis. J Anat. 219(3):410-417.

Tucker AS. 2007. Salivary gland development. Semin Cell Dev Biol. $18(2): 237-244$

Vandenabeele P, Vanden Berghe T, Festjens N. 2006. Caspase inhibitors promote alternative cell death pathways. Sci STKE. 2006(358):PE44.

Walker JL, Menko AS, Khalil S, Rebustini I, Hoffman MP, Kreidberg JA, Kukuruzinska MA. 2008. Diverse roles of E-cadherin in the morphogensis of the submandibular gland: insights into the formation of acinar and ductal structures. Dev Dyn. 237(11):3121-3141.

Wang J, Lenardo MJ. 2000. Roles of caspases in apoptosis, development, and cytokine maturation revealed by homozygous gene deficiencies. J Cell Sci, 113(Pt 5):753-757.

Wells KL, Patel N. 2010. Lumen formation in salivary gland development. Front Oral Biol. 14:78-89. 